\title{
De arbeidsmarkt naar opleiding en beroep tot 1994
}

\author{
Citation for published version (APA):
}

Researchcentrum voor Onderwijs en Arbeidsmarkt, ROA. (1991). De arbeidsmarkt naar opleiding en beroep tot 1994: Prototype. Researchcentrum voor Onderwijs en Arbeidsmarkt, Faculteit der Economische Wetenschappen. ROA Reports No. 005 https://doi.org/10.26481/umarep.1991005

Document status and date:

Published: 01/01/1991

DOI:

10.26481/umarep.1991005

Document Version:

Publisher's PDF, also known as Version of record

\section{Please check the document version of this publication:}

- A submitted manuscript is the version of the article upon submission and before peer-review. There can be important differences between the submitted version and the official published version of record.

People interested in the research are advised to contact the author for the final version of the publication, or visit the DOI to the publisher's website.

- The final author version and the galley proof are versions of the publication after peer review.

- The final published version features the final layout of the paper including the volume, issue and page numbers.

Link to publication

\footnotetext{
General rights rights.

- You may freely distribute the URL identifying the publication in the public portal. please follow below link for the End User Agreement:

www.umlib.nl/taverne-license

Take down policy

If you believe that this document breaches copyright please contact us at:

repository@maastrichtuniversity.nl

providing details and we will investigate your claim.
}

Copyright and moral rights for the publications made accessible in the public portal are retained by the authors and/or other copyright owners and it is a condition of accessing publications that users recognise and abide by the legal requirements associated with these

- Users may download and print one copy of any publication from the public portal for the purpose of private study or research.

- You may not further distribute the material or use it for any profit-making activity or commercial gain

If the publication is distributed under the terms of Article $25 \mathrm{fa}$ of the Dutch Copyright Act, indicated by the "Taverne" license above, 
DE ARBEIDSMARKT NAAR OPLEIDING EN BEROEP TOT 1994

\section{PROTOTYPE}

ROA-R-1991/5

RESEARCHCENTRUM VOOR ONDERWIJS EN ARBEIDSMARKT

Faculteit der Economische Wetenschappen

Rijksuniversiteit Limburg

Maastricht, augustus 1991 


\section{CIP-GEGEVENS KONINKLIJKE BIBLIOTHEEK, DEN HAAG}

Arbeidsmarkt

De arbeidsmarkt naar opleiding en beroep tot 1994: prototype / [Researchcentrum voor Onderwijs en Arbeidsmarkt]. - Maastricht : Researchcentrum voor Onderwijs en Arbeidsmarkt, Faculteit der Economische Wetenschappen, Rijksuniversiteit Limburg. - (Rapport I Researchcentrum voor Onderwijs en Arbeidsmarkt. ISSN 0922-8098; 1991/5)

Met lit. opg.

ISBN 90-5321-066-0 geb.

Trefw.: arbeidsmarkt ; Nederland ; toekomst / onderwijs en arbeidsmarkt ; Nederland ; toekomst. 
DE ARBEIDSMARKT NAAR OPLEIDING EN BEROEP TOT 1994

PROTOTYPE

ROA-R-1991/5

RESEARCHCENTRUM VOOR ONDERWIJS EN ARBEIDSMARKT

Faculteit der Economische Wetenschappen

Rijksuniversiteit Limburg

Maastricht, augustus 1991 


\section{INHOUDSOPGAVE}

Bladzijde

VOORWOORD

2. STROMEN OP DE ARBEIDSMARKT 3

2.1. Inleiding 3

2.2. Uitbreidingsvraag, vervangingsvraag en uitstroom 6

3. DE MARKTPOSITIE VAN OPLEIDINGEN EN BEROEPSKLASSEN 17

$\begin{array}{ll}3.1 . \text { Inleiding } & 17\end{array}$

3.2. De arbeidsmarktperspectieven: vraag en aanbod geconfronteerd 17

3.3. De marktpositie van beroepsklassen 19

$\begin{array}{lr}\text { 3.4. De marktpositie van opleidingen } & 24\end{array}$

4. ONTWIKKELINGEN IN DE KWALIFICATIESTRUCTUUR EN DE STRUCTUUR VAN DE WERKGELEGENHEID

$\begin{array}{ll}\text { 4.1. Inleiding } & 31\end{array}$

4.2. De ontwikkeling van de kwalificatiestructuur 31

4.3. Veranderingen in de beroepenstructuur 36

4.4. Veranderingen in de opleidingsstructuur 38

5. SEXE, ONDERWIJS EN ARBEIDSMARKT 442

5.1. Inleiding 42

5.2. Participatiegraad, deeltijdarbeid en werkloosheid 42

5.3. Onderwijs- en beroepssegregatie $\quad 45$

5.4. Arbeidsmarktkarakteristieken van vrouwenberoepen $\quad 49$

5.5. Arbeidsmarktkarakteristieken van vrouwenopleidingen 52

$\begin{array}{lr}\text { LITERATUUR } & 55\end{array}$

BIJLAGE 1: Uitbreidingsvraag 1989-1994 per beroepsklasse, absoluut en als percentage van het aantal werkzame personen in 1989

BIJLAGE 2: Vervangingsvraag 1989-1994 per beroepsklasse, absoluut en als percentage van het aantal werkzame personen in 1989

BIJLAGE 3: Aantal baanopeningen naar opleidingstype in 1989-1994, absoluut en als percentage van het aantal werkzame personen in 1989, uitgesplitst in uitbreidings- en vervangingsvraag 
BIJLAGE 4: Uitstroom van schoolverlaters, per opleidingstype in 1989-1994, absoluut en als percentage van het aantal werkzame personen in 1989

BIJLAGE 5: Arbeidsmarktperspectieven per opleidingstype 1994

BIJLAGE 6: Het aantal werknemers jonger dan 30 jaar en de conjunctuurgevoeligheid $\left(\mathrm{FI}_{\mathrm{b}}\right)$ per beroepsklasse

BIJLAGE 7: Het relatief aanzien en het gewogen functieniveau per beroepsklasse

BIJLAGE 8: Het werkloosheidspercentage en de uitwijkmogelijkheden op aansluitend functieniveau $(\mathrm{GH})$

BIJLAGE 9: Onderbenutting en het gemiddelde functieniveau per opleidingstype in 1985 en het gemiddelde functieniveau

BIJLAGE 10: De belangrijkste opleidingsachtergronden van de beroepsbeoefenaren in vrouwenberoepen naar sexe in 1985 (tussen haakjes: in procenten)

BIJLAGE 11: De belangrijkste beroepen van beroepsoefenaren met vrouwenopleiding als opleidingsachtergrond naar sexe in 1985 (tussen haakjes: in procenten) 


\section{VOORWOORD}

In opdracht van het Ministerie van Onderwijs en Wetenschappen ontwikkelt het Researchcentrum voor Onderwijs en Arbeidsmarkt (ROA) het Informatiesysteem OnderwijsArbeidsmarkt, dat tot doel heeft om actuele informatie te verschaffen over de arbeidsmarkt in relatie tot het onderwijs, en prognoses te geven over de aansluiting tusen beide subsystemen op de korte en middellange termijn. Een belangrijke toepassing van dit informatiesysteem betreft het geautomatiseerde informatiesysteem voor studie- en beroepskeuze I-See!. Dit systeem is een project van het Landelijk Dienstverlenend Centrum voor Studie- en Beroepskeuzevoorlichting (LDC). I-See! bevat een aanzienlijke hoeveelheid gegevens op CD-ROM over ruim 17.000 opleidingen en circa 1500 beroepen. Deze gegevens zijn in I-See! gekoppeld aan de door het ROA verstrekte arbeidsmarktinformatie over zowel beroepen als opleidingen. Daarmee wordt voorzien in een belangrijke informatiebehoefte op het terrein van de studie- en beroepskeuze.

De toepassingsmogelijkheden van het Informatiesysteem Onderwijs-Arbeidsmarkt van het ROA zijn echter breder. Het ROA is dit programmeringsjaar ${ }^{1}$ gestart met enkele projecten die beogen de toepassingsmogelijkheden en de beleidsrelevantie van het informatiesysteem te vergroten. Een van die projecten betreft het analyseren van de mogelijkheden om het informatiesysteem te regionaliseren, zodat ook een bijdrage kan worden geleverd aan de databehoefte op regionaal niveau (RBA's, regionaal bedrijfsleven, provinciale en gemeentelijke overheden). Een ander project betreft de ontwikkeling van een periodiek verschijnend rapport ten behoeve van het beleid, waarin de belangrijkste gegevens uit het informatiesyteem nader worden geanalyseerd. Het is de bedoeling dat dit rapport, evenals de daaraan ten grondslag liggende prognoses, tweejaarlijks wordt geactualiseerd.

Voor $\mathrm{u}$ ligt het prototype van een dergelijke beleidsgerichte rapportage. Het rapport is bedoeld ter ondersteuning van de beleidsvorming door overheid, arbeidsvoorziening, sociale partners en het onderwijsveld. In het rapport zijn prognoses opgenomen die het ROA heeft gemaakt voor de periode 1989-1994. Aan de hand van een evaluatieronde met de belangrijkste gebruikers zal het rapport in het najaar van 1991 een meer definitieve vorm krijgen op basis van de op dat moment volledig geactualiseerde prognoses. Het wordt daarom bijzonder op prijs gesteld om reacties of suggesties van gebruikers te mogen ontvangen. $U$ kunt deze reacties vóór 1 oktober 1991 doen toekomen aan het ROA, t.a.v. dr. R.K.W. van der Velden.

1. Zie ROA (1990), Het informatiesysteem onderwijs-arbeidsmarkt, onderzoekprogramma 1990/1991, Maastricht (ROA-R-1990/4). 
-ii-

De opbouw van het Informatiesysteem Onderwijs-Arbeidsmarkt stond onder leiding van prof. dr. J.A.M. Heijke. De dagelijkse leiding berustte bij dr. A. de Grip. De gegevens uit dit informatiesysteem hebben ten grondslag gelegen aan het voorliggende rapport. Dr. R.K.W. van der Velden was binnen het ROA verantwoordelijk voor de specifiek ten behoeve van deze rapportage verrichte analyses en tevens voor de eindredactie. Bijdragen zijn geleverd door drs. Th.B.J. Beekman, drs. R.J.P. Dekker, dr. A. de Grip en drs. P. van de Loo. P. Ghijsen verleende assistentie bij de verwerking van de gegevens.

Maastricht, april 1991.

Prof. dr. J.A.M. Heijke

Directeur 


\section{INLEIDING}

De basis voor de voorliggende rapportage wordt gevormd door de gegevens die beschikbaar zijn of binnen afzienbare tijd beschikbaar komen in het Informatiesysteem Onderwijs-Arbeid, dat door het ROA wordt ontwikkeld in opdracht van het Ministerie van Onderwijs en Wetenschappen. De doelstelling van de rapportage is om de belangrijkste trends op de arbeidsmarkt te signaleren, waarbij de nadruk ligt op de kwantitatieve aansluiting tussen opleiding en beroep en de verwachte ontwikkelingen hierin. Het rapport is in eerste instantie bedoeld voor diegenen die zich beleidsmatig met deze problematiek bezig houden: overheid, arbeidsvoorziening, sociale partners en het onderwijsveld.

Het rapport geeft een beschrijving van de belangrijkste ontwikkelingen op de arbeidsmarkt en behandelt een aantal inhoudelijke thema's. Het onderscheidt zich van andere arbeidsmarktrapporten (Rapportage Arbeidsmarkt van het Ministerie van Sociale Zaken en Werkgelegenheid, OSA Trendrapport, CPB Toekomstverkenningen) door de toespitsing op prognoses met betrekking tot de aansluiting tussen onderwijs en arbeidsmarkt, alsmede door het lage aggregatieniveau waarop informatie wordt verstrekt.

In het Informatiesysteem worden 21 sectoren, 77 beroepsklassen en 54 opleidingstypen onderscheiden. De bedrijfstakken zijn gebaseerd op de indeling die het Centraal Planbureau hanteert in het Centraal Economisch Plan. De beroepsklassen komen overeen met het 2-digit niveau van de beroepenclassificatie van het $\mathrm{CBS}^{2}$. De opleidingen zijn op basis van de Standaard Onderwijs Indeling (3 digit) verdeeld in 54, voor de arbeidsmarkt relevante opleidingstypen.

In het voorliggende rapport zijn geen beroepen- en opleidingenprognoses opgenomen van derden. De reden hiervoor is dat dit over de volle breedte van de arbeidsmarkt niet mogelijk is op het lage aggregatieniveau dat hier wordt gehanteerd. Op basis van een vergelijking van een viertal prognosestudies van CPB, Ministerie van Onderwijs en Wetenschappen, SEO en ROA over de periode 1985-'92, op een overigens veel hoger aggregatieniveau, komt de werkgroep "vergelijking en afstemming prognoses '89" van de interdepartementale Commissie Onderwijs Arbeidsmarkt Prognoses overigens tot de conclusie dat de belangrijkste voorspelde trends

2. Met ingang van komend jaar zal een nieuwe beroepsgroepen-indeling worden gehanteerd die meer adequaat is voor de analyse van aansluitingsproblemen. Deze nieuwe indeling is gebaseerd op de opleidingskenmerken van de werkenden in een beroepsgroep (zie Dekker, De Grip en Van de Loo, 1990). 
overeenkomen en dat eventuele verschillen op de gebruikte methodiek teruggevoerd moeten worden (Commissie OAP, 1989).

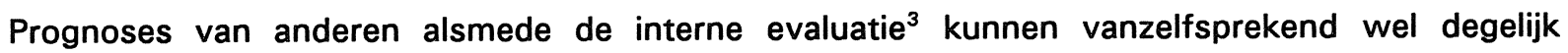
aanleiding vormen om de eigen prognosemodellen bij te stellen. Zo is in navolging van het CPB (Kuhry en Van Opstal, 1987) nagegaan in hoeverre het mogelijk is de werkgelegenheidsontwikkeling naar beroep en opleiding te modelleren met behulp van een multinomiaal logit-model (Peeters, 1990). Daarnaast staat in de werkwijze van het ROA voorop dat voorzover mogelijk wordt aangesloten bij bestaande CPB prognoses van de werkgelegenheidsontwikkeling naar bedrijfstak en bij de recentelijk naar het Ministerie van Onderwijs en Wetenschappen overgehevelde SKILL-prognoses van de uitstroom van schoolverlaters uit het dagonderwijs.

De verdere opbouw van het rapport is als volgt. Hoofdstuk 2 geeft een algemene impressie van de belangrijkste stromen op de arbeidsmarkt. In hoofdstuk 3 worden toekomstige vraag en aanbod op de arbeidsmarkt met elkaar geconfronteerd en wordt ingegaan op de marktpositie van beroepsklassen en opleidingstypen. Hoofdstuk 4 analyseert de structuurverschuivingen tussen 1979 en 1994, zowel naar sector en beroep, als naar opleiding. Tenslotte staat in hoofdstuk 5 de arbeidsmarktpositie van vrouwen centraal. De bijlagen bevatten uitgebreide statistische informatie over de in het rapport onderscheiden beroepsklassen en opleidingen.

3. De opzet van het informatiesysteem is terug te vinden in de verschillende programmeringsrapporten van het ROA. Onlangs is ook een eerste evaluatierapport verschenen, waarin enerzijds wordt ingegaan op de gehanteerde werkwijzen bij de diverse onderdelen van het informatiesysteem en anderzijds een eerste evaluatie plaatsvindt van de prognoseresultaten. 


\section{STROMEN OP DE ARBEIDSMARKT}

\subsection{Inleiding}

Arbeidsmarktprognoses kunnen worden onderverdeeld in prognoses die betrekking hebben op de situatie op een bepaald toekomstig tijdstip en prognoses met betrekking tot een bepaalde toekomstige periode. De laatstgenoemde 'stroomcijfers' aanpak maakt het mogelijk op inzichtelijke wijze de verschillende onderliggende vraag- en aanbodfactoren in beeld te brengen. Voor deze opzet is binnen het ROA-informatiesysteem gekozen. Aan de vraagzijde wordt daarbij een onderscheid gemaakt tussen enerzijds de verwachte uitbreidingsvraag op grond van de verandering van de werkgelegenheid voor een bepaald beroep of opleiding en anderzijds de verwachte vervangingsvraag vanwege pensionering, tijdelijke terugtrekking van de arbeidsmarkt, mobiliteit op de arbeidsmarkt e.d. Daartegenover staat aan de aanbodzijde van de arbeidsmarkt de verwachte toekomstige instroom van schoolverlaters op de arbeidsmarkt en het aanbod van (kortdurig) werklozen (zie schema 2.1.).

De prognoses hebben betrekking op de periode 1989-1994. Uitgangspunt vormen de werkgelegenheidsprognoses van het Centraal Planbureau (CPB) voor 21 bedrijfssectoren. Deze prognoses hebben betrekking op het arbeidsvolume. Op basis van een inschatting van het CPB van de verwachte toename van het werken in deeltijd kunnen deze prognoses worden uitgedrukt in werkzame personen. De aldus verkregen werkgelegenheidsontwikkeling naar bedrijfssector wordt vervolgens omgerekend naar de verwachte werkgelegenheidsontwikkeling voor 77 beroepsklassen. Basis voor deze berekening is het ROA-beroepenmodel, waarmee de beroepenstructuur van bedrijfssectoren kan worden geprognosticeerd. De ontwikkelingen in de beroepenstructuur worden daarbij verklaard uit de technologische ontwikkeling, conjuncturele factoren en structurele (trend)effecten (zie ook Dekker, De Grip en Heijke, 1990). Op deze wijze kan de verwachte uitbreidingsvraag (de werkgelegenheidsontwikkeling) naar beroepsklasse worden berekend.

De vervangingsvraag per beroepsklasse wordt bepaald met behulp van een cohort-analyse van de uitstroom naar geslacht en leeftijdsklasse per beroepsklasse. De in de analyseperiode vastgestelde uitstroomquotes voor de onderscheiden leeftijdsgroepen worden vervolgens gecorrigeerd voor de conjuncturele component in het verloop in de analyseperiode (de uitstroom van werkenden naar het werklozenbestand). Bovendien vindt een correctie plaats van de verwachte ontwikkelingen in de algehele participatiegraad naar geslacht en leeftijd (zie Willems en De Grip, 1990). 
Schema 2.1. Vraag en aanbod op de arbeidsmarkt

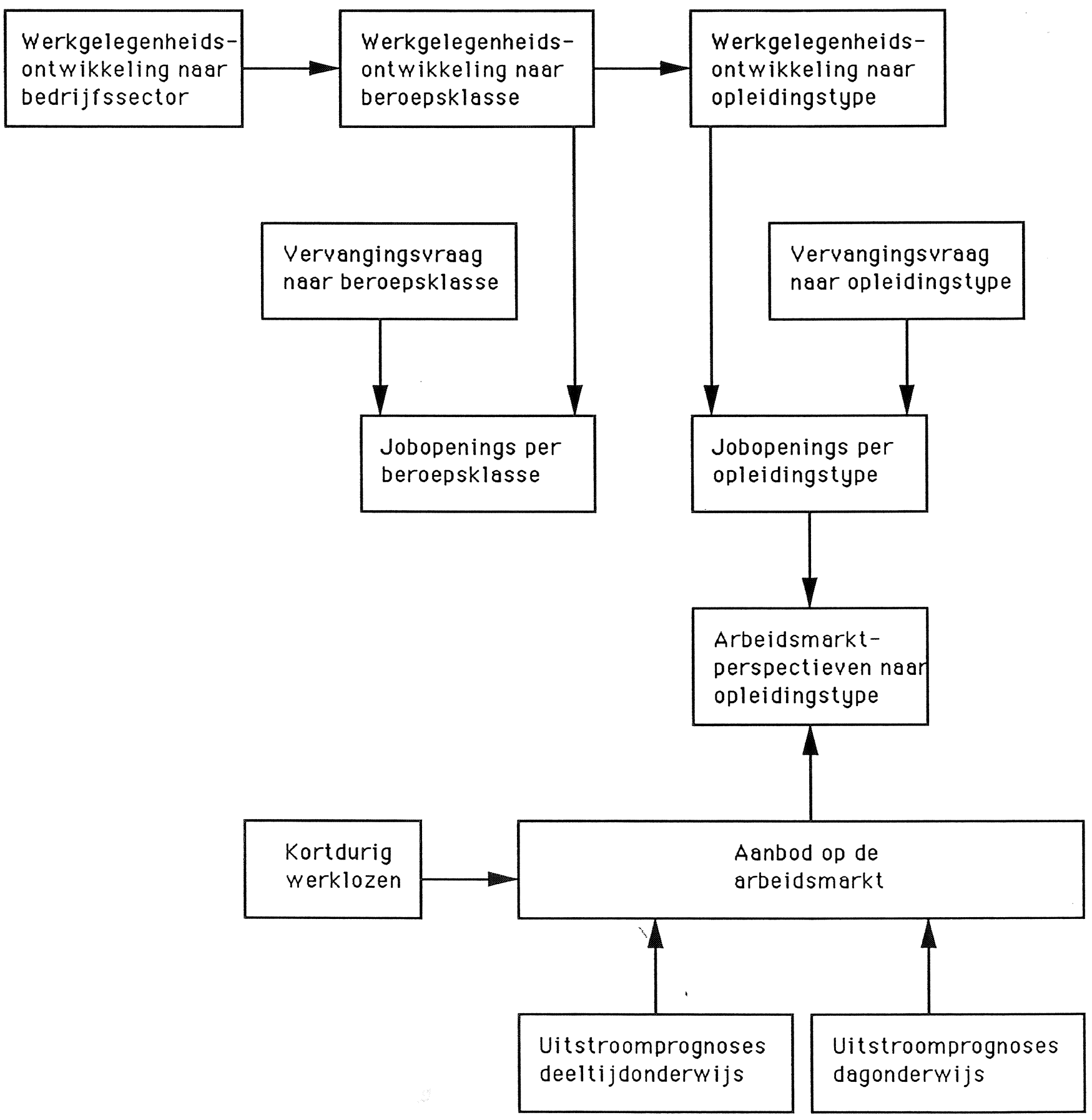


De uitbreidingsvraag en de vervangingsvraag tezamen geven per beroepsklasse het voor de prognoseperiode verwachte aantal baanopeningen per beroepsklasse.

De verwachte uitbreidingsvraag per opleidingstype wordt bepaald met behulp van het ROAopleidingenmodel (zie ook Beekman, Dekker, De Grip en Heijke, 1989). Dit model analyseert de ontwikkeling van de opleidingenstructuur van beroepsklassen op bedrijfssectorniveau. Deze ontwikkeling wordt verklaard vanuit zowel vraagfactoren (technologische ontwikkeling) als aanbodfactoren (substitutie of verdringing). Technologische ontwikkelingen bieden daarbij een verklaringsgrond voor een toename (of afname) van het voor de uitoefening van een bepaald beroep vereiste opleidingsniveau. Men spreekt in dit verband wel van respectievelijk upgrading en downgrading. De daadwerkelijk op de arbeidsmarkt gevraagde opleiding wordt daarnaast ook beïnvloed door de relatieve schaarste van de verschillende opleidingscategorieën. Al dan niet via een aanpassing van de relatieve beloning zal een toenemend aanbod van een bepaalde opleidingscategorie op grond van dit mechanisme ook leiden tot een toenemende vraag naar het desbetreffende opleidingstype.

De prognose van de uitbreidingsvraag per opleidingstype wordt eveneens aangevuld met een prognose van de vervangingsvraag. Deze laatste prognose wordt op soortgelijke wijze bepaald als de vervangingsvraag per beroepklasse. Een belangrijk verschil dat zich daarbij voordoet is wel dat de beroepsmobiliteit niet van invloed is op de vervangingsvraag naar opleidingstype. Gemiddeld genomen is de vervangingsvraag per opleidingstype derhalve kleiner dan de vervangingsvraag per beroepsklasse (zie Willems en De Grip, 1990).

De baanopeningen per opleidingstype (de som van de uitbreidings- en vervangingsvraag) worden vervolgens geconfronteerd met de prognose van de verwachte uitstroom van schoolverlaters op de arbeidsmarkt. Deze aanbodzijdeprognose wordt opgesteld met behulp van de diverse prognoses van het Ministerie van Onderwijs en Wetenschappen en uiteenlopende gegevens over de verwachte uitstroom uit het deeltijdonderwijs (zie ook De Grip, Dekker en Heijke, 1989). Bij de uiteindelijke confrontatie van vraag en aanbod naar opleidingstype worden de berekende stroomgrootheden weer omgezet in standcijfers, waarbij ook rekening wordt gehouden met de reeds werkzame bevolking en het aanbod van kortdurig werklozen aan het begin van de prognoseperiode. Op basis van deze confrontatie worden uitspraken gedaan over de verwachte toekomstige arbeidsmarktperspectieven naar opleidingstype.

In dit hoofdstuk zal de uitbreidingsvraag en vervangingsvraag van zowel beroepsklassen als opleidingstypen aan bod komen. Voorts worden gegevens gepresenteerd over de verwachte uitstroom van schoolverlaters naar de arbeidsmarkt. De confrontatie van beide typen gegevens 
zal in het volgende hoofdstuk plaatsvinden.

\subsection{Uitbreidingsvraag, vervangingsvraag en uitstroom}

In figuur 2.1 wordt een schets gegeven van de ontwikkeling van de totale werkgelegenheid in Nederland voor de periode 1979 - 1994. De gegevens betreffen door het ROA bewerkte cijfers van het CPB.

Figuur 2.1. Ontwikkeling werkgelegenheid (arbeidsvolume en werkzame personen)

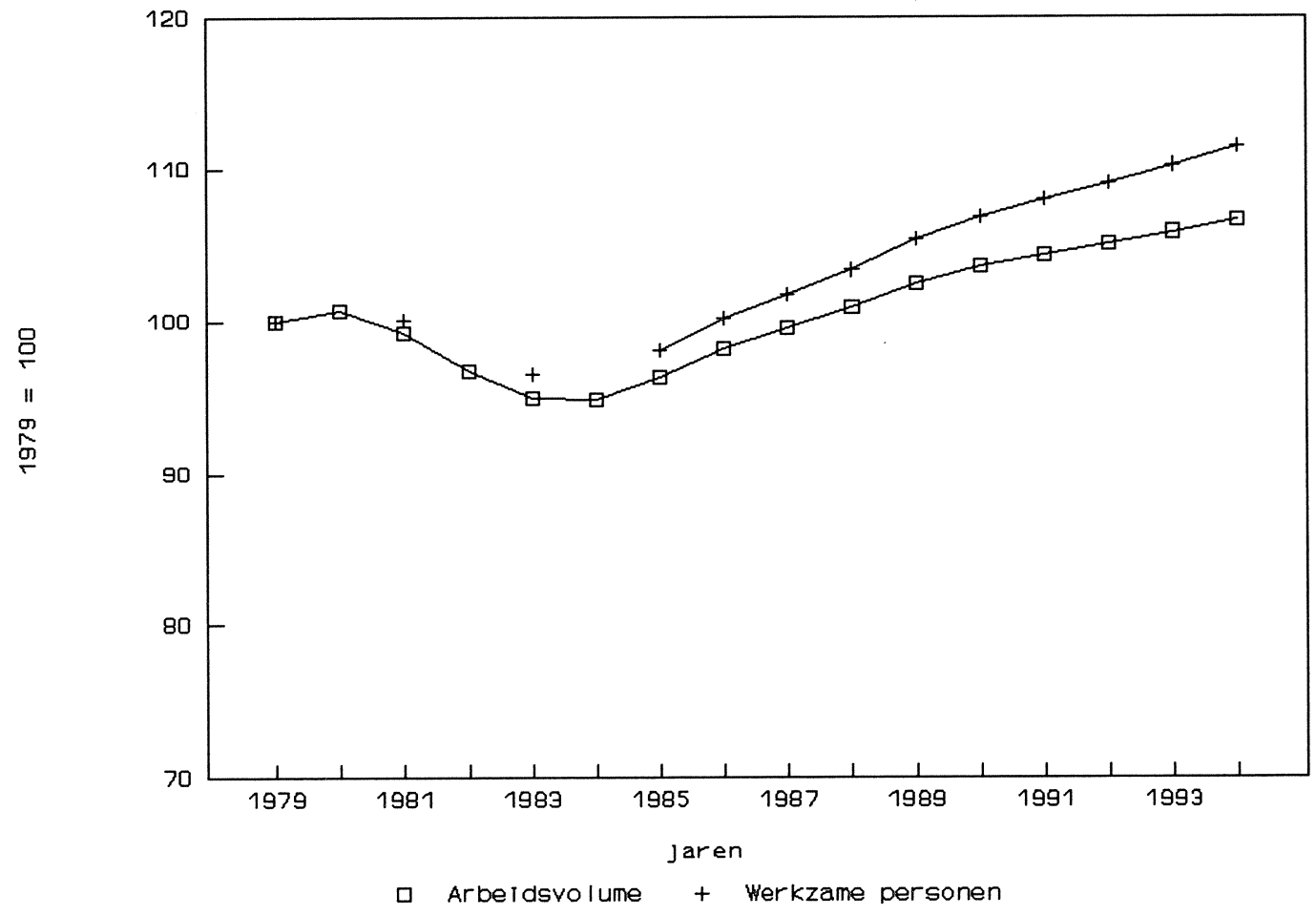

Bron: $\mathrm{CPB} / \mathrm{ROA}$

Het totaal aantal werkzame personen bedroeg in 1979 ruim 5.2 milioen personen. Na een daling in het begin van de jaren ' 80 , stijgt vanaf 1984 de totale werkgelegenheid weer met een gemiddelde groeivoet van $1.8 \%$ per jaar. Voor de prognoseperiode 1989-1994 wordt opnieuw een groei van het aantal werkzame personen voorspeld. In totaal gaat het daarbij om een groei van 315.000 personen. De groeivoet vlakt echter af tot zo'n $1.1 \%$ per jaar. 
De ontwikkeling van het arbeidsvolume toont een relatief ongunstiger ontwikkeling: de daling in het begin van de jaren ' 80 is sterker geweest dan de daling in het aantal werkzame personen, terwijl de groei vanaf het midden van de jaren ' 80 juist minder sterk is geweest. Het verschil tussen beide ontwikkelingen heeft uiteraard te maken met de groei van deeltijdwerkenden.

Tabel 2.1. geeft aan hoe het arbeidsvolume zich in de verschillende sectoren heeft ontwikkeld. Gepresenteerd worden de gemiddelde jaarlijkse groeivoeten in drie onderscheiden periodes: 1979-1985, 1985-1989 en 1989-1994. De cijfers zijn gebaseerd op de gegevens van het CPB. De drie onderscheiden perioden komen grofweg overeen met drie conjunctuurfasen die onderscheiden kunnen worden: een periode van sterke economische neergang (tot 1984), een periode van sterke economische groei (tot 1989) en de prognoseperiode, waarvoor een gematigde groei wordt voorspeld.

Tabel 2.1. Ontwikkeling arbeidsvolume naar sector 1979-1994 (gemiddelde jaarlijkse groeivoeten)

\begin{tabular}{|c|c|c|c|c|}
\hline & & $\begin{array}{c}1979 / 85 \\
\%\end{array}$ & $\begin{array}{c}1985 / 89 \\
\%\end{array}$ & $\begin{array}{c}1989 / 94 \\
\%\end{array}$ \\
\hline 1 & Landbouw, visserij en bosbouw & -0.5 & -0.5 & -0.5 \\
\hline 2 & Voedings- en genotmiddelenindustrie & -1.5 & -0.2 & -1.0 \\
\hline 3 & Textiel, kleding-, en leder- en schoenindustrie & -5.6 & 0.5 & -0.9 \\
\hline 4 & Hout- en bouwmaterialenindustrie & -4.0 & 3.0 & 0.0 \\
\hline 5 & Papier- en grafische industrie & -1.2 & 2.4 & 0.0 \\
\hline \multirow[t]{2}{*}{6} & Chemische, rubber- en kunststofverwerkende & & & \\
\hline & industrie & 0.0 & 2.3 & 1.6 \\
\hline 7 & Basismetaalindustrie & -0.5 & 0.0 & 0.2 \\
\hline 8 & Metaalprodukten- en optische industrie & -1.8 & 1.5 & 0.5 \\
\hline 9 & Electrotechnische industrie & -1.5 & 0.0 & 0.2 \\
\hline 10 & Transportmiddelenindustrie & -2.6 & -0.8 & 0.2 \\
\hline 11 & Delfstoffenwinning & 1.0 & 0.5 & 0.1 \\
\hline 12 & Openbare nutsbedrijven & 1.0 & 0.5 & 0.1 \\
\hline 13 & Bouwnijverheid & -4.5 & 2.6 & -0.2 \\
\hline 14 & Handel & -1.0 & 2.5 & 2.2 \\
\hline 15 & Zee- en luchtvaart & 0.4 & 2.2 & 1.3 \\
\hline \multirow[t]{2}{*}{16} & Overige transport-, opslag- en & & & \\
\hline & communicatiebedrijven & 0.4 & 2.2 & 1.3 \\
\hline 17 & Bank- en verzekeringswezen & 0.7 & 1.4 & 1.7 \\
\hline 18 & Overige tertiaire diensten & 0.6 & 3.4 & 1.8 \\
\hline 19 & Medische en veterinaire diensten & 1.7 & 1.5 & 0.7 \\
\hline 20 & Overige kwartaire diensten & 1.4 & 1.5 & 0.9 \\
\hline \multirow[t]{2}{*}{21} & Overheid & 0.8 & 0.4 & -0.1 \\
\hline & Totaal & -0.6 & 1.6 & 0.8 \\
\hline
\end{tabular}

Bron: $\mathrm{CPB} / \mathrm{ROA}$

De recessie in het begin van de jaren ' 80 heeft met name een ongunstig effect gehad op de textiel- en kledingindustrie, de hout- en bouwmaterialenindustrie en de bouwnijverheid. De 
kwartaire sector, en met name de medische en veterinaire diensten en de overige kwartaire diensten, laat in deze periode juist een groei van het arbeidsvolume zien. Het beeld in de tweede helft van de jaren ' 80 is anders. Sectoren die sterk profiteren van de economische groei zijn: overige tertiaire diensten en woningbouw, de hout- en bouwmaterialenindustrie, de handel, de bouwnijverheid en de papier- en grafische industrie.

Voor de prognoseperiode zijn de verschillen in de ontwikkeling van het arbeidsvolume tussen sectoren minder pregnant. Voor de voedings- en genotmiddelenindustrie, de textiel- en kledingindustrie, en landbouw en visserij wordt een lichte daling verwacht van het arbeidsvolume. Groeisectoren betreffen de handel, overige tertiaire diensten en woningbouw, het bank- en verzekeringswezen, de chemische industrie, de transportsector, en de kwartaire sector.

Tabel 2.2. Sterk groeiende beroepsklassen in de periode 1989-1994

\section{Absoluut}

\begin{tabular}{|c|c|c|c|}
\hline CBS & beroepsklasse & $\begin{array}{l}\text { absoluut } \\
\text { aantal }\end{array}$ & $\begin{array}{c}\text { in } \% \\
\text { t.o.v. } 1989\end{array}$ \\
\hline 97 & Laders, lossers, inpakkers e.d. & 46600 & 25 \\
\hline 08 & Statistici, systeemanalisten e.d. & 45400 & 57 \\
\hline 21 & Leidinggevenden excl. openb. best. & 42300 & 20 \\
\hline 48 & Winkelbedienden e.a. verkopers & 29700 & 10 \\
\hline 37 & Post-distributiepersoneel & 22000 & 36 \\
\hline $02 / 03$ & Architecten, ingenieurs, tekenaars e.d. & 21200 & 11 \\
\hline 06/07 & Genees- en verpleegkundig personeel & 20200 & 7 \\
\hline 33 & Boekhouders, kassiers e.d. & 12600 & 4 \\
\hline 43 & Zelfst. winkeliers/detailhandelaren & 12300 & 12 \\
\hline 39 & Administratieve functies n.e.g. & 10700 & 3 \\
\hline \multicolumn{4}{|c|}{ Relatief } \\
\hline CBS & beroepsklasse & $\begin{array}{l}\text { absoluut } \\
\text { aantal }\end{array}$ & $\begin{array}{c}\text { in } \% \\
\text { t.o.v. } 1989\end{array}$ \\
\hline 08 & Statistici, systeemanalisten e.d. & 45400 & 57 \\
\hline 37 & Post-distributiepersoneel & 22000 & 35 \\
\hline 15 & Auteurs, jounalisten e.d. & 7400 & 26 \\
\hline 97 & Laders, lossers, inpakkers, e.d. & 46600 & 25 \\
\hline 21 & Leidinggevenden excl. openb. best. & 42300 & 20 \\
\hline 43 & Zelfst. winkeliers/detailhandelaren & 12300 & 12 \\
\hline 40 & Directeur/bedr.leiders groothandel & 4600 & 12 \\
\hline 42 & Zelfst. groothandelaren & 3500 & 12 \\
\hline 41 & Directeur/bedr.leiders detailhandel & 2100 & 12 \\
\hline $02 / 03$ & Architecten, ingenieurs, tekenaars e.d. & 21200 & 11 \\
\hline
\end{tabular}


Tabel 2.2. geeft aan welke beroepsklassen het meest profiteren van de werkgelegenheidsgroei in de periode 1989-1994. Het bovenste gedeelte van de tabel geeft aan welke beroepsklassen absoluut gezien het sterkst stijgen. Het onderste gedeelte geeft aan welke beroepsklassen relatief sterk stijgen. De toename van de werkgelegenheid wordt daarbij uitgedrukt in procenten van het aantal werkzame personen in die beroepsklasse in 1989.

Beroepsklassen die absoluut gezien zeer sterk in omvang toenemen zijn de laders en lossers, de statistici en systeemanalisten, en het leidinggevend personeel. De groei in deze drie beroepsklassen (in totaal 135.000 personen) is goed voor ruim $40 \%$ van de totale groei in de werkgelegenheid in deze periode. Sterk groeiende beroepsklassen betreffen verder het winkelpersoneel, het post-distributiepersoneel, architecten, ingenieurs, tekenaars e.d. en genees- en verpleegkundig personeel. Bij deze laatste beroepsklasse is echter de groei relatief gezien niet zo groot. Hetzelfde geldt voor boekhouders en kassiers, en overige administratieve functies. Er zijn maar zes beroepsklassen die zowel in absolute als in relatieve zin tot de 'occupational winners' (De Grip, 1987) behoren. Tot de kleinere beroepsklassen die relatief sterk stijgen behoren de auteurs en journalisten, en de zelfstandigen in de detail- en groothandel.

Tabel 2.3. Sterk dalendende beroepsklassen in de periode 1989-1994

\begin{tabular}{|c|c|c|c|}
\hline CBS & beroepsklasse & $\begin{array}{l}\text { absoluut } \\
\text { aantal }\end{array}$ & $\begin{array}{c}\text { in } \% \\
\text { t.o.v. } 1989\end{array}$ \\
\hline 45 & Leidinggevend commercieel personeel & -7100 & -18 \\
\hline 83 & Smeden, gereedschapmakers e.d. & -3900 & -14 \\
\hline 61 & Zelfstandige land- en tuinbouwers & -3500 & -3 \\
\hline 38 & Telefonisten, telegrafisten e.d. & -3300 & -23 \\
\hline 76 & Schoenmakers; lederwarenmakers & -3290 & -5 \\
\hline 95 & Metselaars e.a. bouwvakarbeiders & -3200 & -2 \\
\hline 62 & Agrarische arbeiders & -2300 & -2 \\
\hline 92 & Drukkers en verwante functies & -2100 & -5 \\
\hline 98 & Chauffeurs, matrozen, treinbest. & -1400 & -1 \\
\hline 85 & Elektromonteurs, -reparateurs e.d. & -1100 & -1 \\
\hline
\end{tabular}

Tabel 2.3. geeft aan welke beroepsklassen volgens de prognose sterk zullen dalen. Vergelijkt men de cijfers met die van tabel 2.2., dan valt allereerst op dat de groeicijfers veel spectaculairder zijn dan de krimpcijfers. Een betrekkelijk sterk dalende beroepsklasse betreft het leidinggevend commercieel personeel, hetgeen opvallend is omdat het overige leidinggevend personeel juist tot de groeiers behoort. Overige dalers betreffen vooral traditionele industrieberoepen, en landbouwberoepen. In de tabel staat ook vermeld hoe groot de relatieve daling is geweest. Vooral voor telefonisten en telegrafisten, leidinggevend commercieel 
personeel, en smeden en gereedschapmakers geldt dat er sprake is van een relatief sterke daling. Bij de overige genoemde beroepsklassen bedraagt de daling slechts enkele procenten ${ }^{4}$.

Tabel 2.4. Beroepsklassen met een hoge vervangingsvraag in de periode 1989-1994

\section{Absoluut}

\begin{tabular}{|c|c|c|c|}
\hline CBS & beroepsklasse & $\begin{array}{l}\text { absoluut } \\
\text { aantal }\end{array}$ & $\begin{array}{c}\text { in } \% \\
\text { t.o.v. } 1989\end{array}$ \\
\hline 48 & Winkelbedienden e.a. verkopers & 55200 & 19 \\
\hline 39 & Administratieve functies n.e.g. & 48100 & 12 \\
\hline 33 & Boekhouders, kassiers e.d. & 38300 & 13 \\
\hline 32 & Secretaressen, typisten e.d. & 27300 & 18 \\
\hline 13 & Leerkrachten & 25300 & 8 \\
\hline 54 & Huishoudelijk en verz. pers. n.e.g. & 25300 & 15 \\
\hline 62 & Agrarische arbeiders & 24300 & 18 \\
\hline 83 & Smeden, gereedschapmakers e.d. & 23500 & 14 \\
\hline 96 & Machinisten, bediener stat. machine & 22500 & 12 \\
\hline 06/07 & Genees- en verpleegkundig personeel & 22100 & 8 \\
\hline
\end{tabular}

Relatief

Van groot belang voor het aantal baanopeningen in een beroepsklasse is niet alleen de groei van de werkgelegenheid, maar ook de zogenaamde vervangingsbehoefte als gevolg van pensionering e.d. (zie tabel 2.4.). Onder de beroepsklassen met een hoge vervangingsvraag (zowel absoluut

4. Er zijn wel andere beroepsklassen met een relatief sterke daling, maar dat betreft erg kleine beroepsklassen, zodat aan de betekenis van deze prognoses geen waarde kan worden gehecht. 
als relatief) treft men veel vrouwenberoepen aan: winkelpersoneel, secretaressen en typisten, overig administratief personeel, telefonisten en telegrafisten, huishoudelijk personeel en geneesen verpleegkundig personeel (zie ook hoofdstuk 6). Een deel van deze beroepsklassen (winkelpersoneel, genees- en verpleegkundig personeel en overig administratief personeel) kent, zoals eerder is aangegeven, ook een hoge absolute uitbreidingsvraag. Absoluut gezien is er ook een grote vervangingsbehoefte bij boekhouders en kassiers, leerkrachten, agrarische arbeiders en enkele industriële beroepen. Een relatief grote vervangingsbehoefte treft men aan bij agrarische arbeiders en beroepsmilitairen. De overige beroepsklassen met een relatief grote vervangingsbehoefte hebben een vrij kleine omvang.

Tabel 2.5. Beroepsklassen met een lage vervangingsvraag in de periode 1989-1994

Absoluut

\begin{tabular}{llrl}
\hline & & & \\
CBS & beroepsklasse & $\begin{array}{c}\text { in } \\
\text { aantal }\end{array}$ & \\
t.o.v. 1989
\end{tabular}

\section{Relatief}


Deels komt men deze kleine beroepsklassen (vissers en jagers) dan ook weer tegen in het rijtje van beroepsklassen met een absoluut gezien lage vervangingsbehoefte (tabel 2.5.). Er zijn vijf beroepsklassen die zowel absoluut als relatief een lage vervangingsbehoefte kennen: tabaksbewerkers, boswachters en bosarbeiders, uitvoerende hoofdambtenaren, meubelmakers en steenhouwers, en overige ambachts- en industrieberoepen. Tegenover de hoge uitbreidingsvraag bij de beroepsklassen van statistici en systeemanalisten, auteurs en journalisten, en het postdistributiepersoneel staat een relatief lage vervangingsvraag.

Tabel 2.6. Opleidingstypen met een hoog aantal baanopeningen in de periode 1989-1994, uitgesplitst in vervangingsvraag en uitbreidingsvraag

Absoluut

\begin{tabular}{|c|c|c|c|c|}
\hline Opleidingstype & $\begin{array}{r}\text { absoluut } \\
\text { aantal }\end{array}$ & $\begin{array}{c}\text { in } \% \\
\text { t.o.v. } 1989\end{array}$ & $\begin{array}{r}\text { aandeel } \\
\text { verv. } \\
\text { vraag } \\
\%\end{array}$ & $\begin{array}{r}\text { aandeel } \\
\text { uitbr. } \\
\text { vraag } \\
\%\end{array}$ \\
\hline MBO Economisch \& Administratief & 227800 & 31 & 15 & 85 \\
\hline MBO Technisch \& Laboratorium & 103700 & 18 & 44 & 56 \\
\hline MAVO en onderbouw HAVO \& VWO & 67000 & 15 & 64 & 36 \\
\hline LBO Technisch & 57100 & 12 & 100 & 0 \\
\hline MBO Sociale Verzorging & 41600 & 29 & 62 & 38 \\
\hline LBO Sociale Verzorging \& Horeca & 41100 & 18 & 85 & 15 \\
\hline Basisonderwijs & 39200 & 6 & 100 & 0 \\
\hline Bovenbouw HAVO \& VWO & 34500 & 15 & 45 & 55 \\
\hline HBO Economisch \& Administratief & 34000 & 24 & 17 & 83 \\
\hline HBO Docentenopleidingen & 25800 & 12 & 68 & 32 \\
\hline
\end{tabular}

Relatief

\begin{tabular}{lcrcr}
\hline Opleidingstype & absoluut & $\begin{array}{r}\text { in } \% \\
\text { aantal }\end{array}$ & $\begin{array}{r}\text { aandeel } \\
\text { verv. } \\
\text { vraag } \\
\%\end{array}$ & $\begin{array}{r}\text { aandeel } \\
\text { uitbr. } \\
\text { vraag } \\
\%\end{array}$ \\
& & & & \\
& & & 5 & 95 \\
WO Econometrie \& Bedrijfskunde (ir) & & 74 & 12 & 88 \\
HBO Technische Bedrijfsunde & 3100 & 42 & 17 & 83 \\
WO Economie \& Bedrijfskunde (drs.) & 1500 & 35 & 15 & 85 \\
MBO Economisch \& Administratief & 10300 & 31 & 62 & 38 \\
MBO Sociale Verzorging & 227800 & 29 & 32 & 68 \\
LBO Vervoer \& Haven & 41600 & 27 & 17 & 83 \\
HBO Economisch \& Administratief & 6200 & 24 & 60 & 40 \\
MBO Ziekenverzorging & 34000 & 24 & 58 & 42 \\
MBO Verpleging & 8700 & 21 & 52 & 48 \\
MBO Medisch Laboratorium & 20700 & 21 & & 58 \\
\hline
\end{tabular}


Tabel 2.7. Opleidingstypen met een laag aantal baanopeningen in de periode 1989-1994, uitgesplitst in vervangingsvraag en uitbreidingsvraag

\begin{tabular}{|c|c|c|c|c|}
\hline Opleidingstype & $\begin{array}{l}\text { absoluut } \\
\text { aantal }\end{array}$ & $\begin{array}{c}\text { in } \% \\
\text { t.o.v. } 1989\end{array}$ & $\begin{array}{r}\text { aandeel } \\
\text { verv. } \\
\text { vraag } \\
\%\end{array}$ & $\begin{array}{r}\text { aandeel } \\
\text { uitbr. } \\
\text { vraag } \\
\%\end{array}$ \\
\hline WO Kunstwetenschappen & 150 & 9 & 55 & 45 \\
\hline LBO Beveiliging \& Bewaking & 300 & 3 & 100 & 0 \\
\hline HBO Tolk \& Vertaler & 350 & 5 & 100 & 0 \\
\hline WO Farmacie & 500 & 13 & 34 & 66 \\
\hline WO Agrarisch & 650 & 11 & 53 & 47 \\
\hline HBO Theologie & 700 & 19 & 62 & 38 \\
\hline HBO Horeca & 750 & 19 & 43 & 57 \\
\hline HBO Politie \& Brandweer \& Defensie & 850 & 11 & 66 & 34 \\
\hline WO Theologie & 1300 & 18 & 81 & 19 \\
\hline HBO Agrarisch & 1300 & 11 & 62 & 38 \\
\hline
\end{tabular}

Relatief

\begin{tabular}{|c|c|c|c|c|}
\hline Opleidingstype & $\begin{array}{l}\text { absoluut } \\
\text { aantal }\end{array}$ & $\begin{array}{c}\text { in } \% \\
\text { t.o.v. } 1989\end{array}$ & $\begin{array}{r}\text { aandeel } \\
\text { verv. } \\
\text { vraag } \\
\%\end{array}$ & $\begin{array}{r}\text { aandeel } \\
\text { uitbr. } \\
\text { vraag } \\
\%\end{array}$ \\
\hline LBO Beveiliging \& Bewaking & 300 & 3 & 100 & 0 \\
\hline HBO Tolk \& Vertaler & 350 & 5 & 100 & 0 \\
\hline Basisonderwijs & 39200 & 6 & 100 & 0 \\
\hline HBO Kunst & 1800 & 7 & 100 & 0 \\
\hline WO Docentenopleidingen & 1500 & 7 & 60 & 40 \\
\hline LBO Agrarisch & 8100 & 8 & 100 & 0 \\
\hline WO Letteren e.d. & 1700 & 8 & 65 & 35 \\
\hline WO Kunstwetenschappen & 150 & 9 & 55 & 45 \\
\hline MBO Bestuurlijk \& Recht & 3800 & 9 & 95 & 5 \\
\hline WO Rechten \& Bestuurskunde & 3300 & 10 & 56 & 44 \\
\hline
\end{tabular}

De uitbreidingsvraag en vervangingsvraag per beroepsklasse is door het ROA omgerekend naar baanopeningen per opleidingstype. Het bovenste gedeelte van tabel 2.6. geeft aan welke opleidingstypen absoluut gezien de sterkste vraag kennen. Het onderste gedeelte geeft aan welke opleidingstypen relatief gezien de sterkste vraag kennen (ten opzichte van het aantal werkzame personen met die opleidingsachtergrond in 1989). MBO Economisch en Administratief, HBO Economisch en Administratief, en MBO Sociale Verzorging kennen zowel absoluut als relatief een groot aantal baanopeningen: bij de eerste twee heeft dit vooral te maken met een hoge uitbreidingsvraag, bij de laatste vooral met een hoge vervangingsvraag. Een sterke vraag in 
absoluut opzicht is er bij de technische opleidingen op LBO- en MBO-niveau, de algemene opleidingen in het voortgezet onderwijs, het basisonderwijs en de HBO docentenopleidingen. Vooral voor de lagere opleidingen (LBO Technisch, Basisonderwijs) geldt dat het aantal baanopeningen voornamelijk vervangingsvraag betreft. Een relatief sterke vraag die vooral betrekking heeft op uitbreidingsvraag, wordt aangetroffen voor WO Econometrie \& Bedrijfskunde, WO Economie \& Bedrijfskunde, LBO Vervoer \& Haven en HBO Technische Bedrijfskunde. Voor de opleidingen MBO Ziekenverzorging, MBO Verpleging en MBO Medisch Laboratorium geldt dat de relatief sterke vraag zowel betrekking heeft op de uitbreidings- als de vervangingsvraag.

Een gering aantal baanopeningen, in zowel relatief als absoluut opzicht, is te verwachten bij WO Kunstwetenschappen, LBO Beveiliging \& Bewaking, en HBO Tolk \& Vertaler (tabel 2.7.). Overige opleidingen waarvoor relatief weinig baanopeningen zijn te verwachten zijn: Basisonderwijs (overigens wel veel in absoluut opzicht), HBO Kunst, WO Docentenopleidingen, LBO Agrarisch, WO Letteren, MBO Bestuurlijk \& Recht en WO Rechten \& Bestuurskunde. De overige opleidingen waarvoor in absoluut opzicht een gering aantal baanopeningen wordt verwacht betreffen enkele kleinere opleidingen op HBO- en WO-niveau.

Bovengenoemde ontwikkelingen spelen zich allemaal af aan de vraagkant van de arbeidsmarkt. Inzicht in de positie van opleidingscategorieën op de arbeidsmarkt is pas te verkrijgen wanneer deze gegevens worden geconfronteerd met de ontwikkelingen aan de aanbodskant van de arbeidsmarkt. Tabel 2.8. geeft een overzicht van opleidingen die voor de prognoseperiode een hoge uitstroom van schoolverlaters te zien geven, in absoluut opzicht of relatief ten opzichte van het aantal werkzame personen met die opleidingsachtergrond in 1989.

Opleidingstypen met een hoge absolute uitstroom betreffen met name opleidingen in het MBO en opleidingen in het voortgezet onderwijs, of schoolverlaters met uitsluitend basisonderwijs. Bedacht moet worden dat schoolverlaters hier zijn ingedeeld naar het hoogst behaalde onderwijsdiploma: de schoolverlaters uit het basisonderwijs betreffen derhalve met name dropouts uit het voortgezet onderwijs. Opleidingen met een relatief gezien hoge uitstroom treft men daarentegen juist aan bij het WO en HBO. In de prognoseperiode 1989-1994 stromen van een aantal van deze opleidingen meer of bijna evenveel schoolverlaters naar de arbeidsmarkt als dat er in 1989 met die opleidingsachtergrond werkzaam waren. Een relatief zeer hoge uitstroom is te verwachten bij WO Kunstwetenschappen (een opleiding die een zeer beperkt aantal baanopeningen te zien gaf), HBO Technische Bedrijfskunde en WO Econometrie \& Bedrijfskunde (twee opleidingen die juist een relatief groot aantal baanopeningen te zien gaven) en WO Letteren. 
Tabel 2.8. Opleidingstypen met een hoge uitstroom van schoolverlaters naar de arbeidsmarkt in 19891994

Absoluut

\begin{tabular}{lrr} 
Opleidingstype & $\begin{array}{c}\text { absoluut } \\
\text { aantal }\end{array}$ & $\begin{array}{c}\text { in } \\
\text { t.o.v. } 1989\end{array}$ \\
\hline MBO Technisch \& Laboratorium & 157500 & 27 \\
Basisonderwijs & 142500 & 23 \\
MBO Economisch \& Administratief & 132800 & 18 \\
Bovenbouw HAVO \& VWO & 126400 & 54 \\
MBO Sociale Verzorging & 70300 & 49 \\
LBO Technisch & 54200 & 11 \\
HBO Docentenopleidingen & 37900 & 18 \\
MAVO en onderbouw HAVO \& VWO & 37200 & 8 \\
MBO Agrarisch & 36700 & 34 \\
HBO Technisch & 35800 & 31 \\
\hline
\end{tabular}

Relatief

WO Kunstwetenschappen

$\begin{array}{rr}164 & 3100 \\ 118 & 4100 \\ 89 & 3700 \\ 83 & 18000 \\ 76 & 9200 \\ 74 & 20900 \\ 73 & 23500 \\ 70 & 4200 \\ 68 & 19700 \\ 61 & 28000\end{array}$

HBO Technische Bedrijfskunde

WO Econometrie \& Bedrijfskunde (ir)

WO Letteren e.d.

HBO Agrarisch

MBO Sociaal \& Cultureel

8000

200

WO Rechten \& Bestuurskunde

3500

WO Agrarisch

WO Economie \& Bedrijfskunde (drs)

28000

HBO Verpleging \& Fysiotherapie

Opleidingen met absoluut gezien een beperkte uitstroom van schoolverlaters betreffen met name opleidingen in het $\mathrm{HBO}$ en het WO (tabel 2.9.). Het gaat hier merendeels om vrij specifieke, kleinschalige opleidingstypen. Opleidingen met een relatief lage uitstroom van schoolverlaters betreffen daarentegen met name opleidingen in het LBO en MBO. Voor de opleidingstypen HBO Tolk \& Vertaler, WO Theologie, LBO Economisch \& Administratief en LBO Vervoer \& Haven geldt dat de uitstroom naar de arbeidsmarkt in zowel absoluut als relatief opzicht beperkt is: voor de opleiding HBO Tolk \& Vertaler compenseert dit wellicht het geringe aantal baanopeningen, voor de opleiding LBO Vervoer \& Haven betekent dit gelet op het relatief hoge aantal baanopeningen wellicht een verscherping van knelpunten in de personeelsvoorziening. In het volgende hoofdstuk komen we op deze confrontatie van vraag en aanbod terug. 
$-16-$

Tabel 2.9. Opleidingstypen met een lage uitstroom van schoolverlaters naar de arbeidsmarkt in 19891994

Absoluut

\begin{tabular}{lrr}
\hline Opleidingstype & $\begin{array}{c}\text { absoluut } \\
\text { aantal }\end{array}$ & $\begin{array}{c}\text { in } \\
\text { t.o.v. } 1989\end{array}$ \\
\hline HBO Tolk \& Vertaler & & 9 \\
HBO Theologie & 650 & 18 \\
WO Theologie & 650 & 10 \\
LBO Vervoer \& Haven & 750 & 5 \\
HBO Politie \& Brandweer \& Defensie & 1000 & 15 \\
WO Farmacie & 1300 & 41 \\
HBO Horeca & 1600 & 55 \\
HBO Medisch Laboratorium & 2100 & 16 \\
WO Docentenopleidingen & 2500 & 14 \\
LBO Economisch \& Administratief & 2800 & 3 \\
\end{tabular}

\section{Relatief}

Opleidingstype

absoluut

aantal

2900

LBO Economisch \& Administratief

LBO Vervoer \& Haven

MAVO en onderbouw HAVO \& VWO

HBO Tolk \& Vertaler

LBO Sociale Verzorging \& Horeca

LBO Agrarisch

WO Theologie

MBO Bestuurlijk \& Recht \& Fiscaal

MBO Politie \& Brandweer \& Defensie

LBO Technisch

HBO Lucht- \& Zeevaart \& Verkeer

1000

37200

650

20700

10300

750

4300

6400

54200

3100 in \%

t.o.v. 1989

3 


\section{DE MARKTPOSITIE VAN OPLEIDINGEN EN BEROEPSKLASSEN}

\subsection{Inleiding}

In dit hoofdstuk wordt nagegaan bij welke opleidingstypen zich naar verwachting schaarsteproblemen zullen gaan voordoen. Daarnaast wordt bekeken welke opleidingstypen grote absorptieproblemen te zien zullen geven. De kans op absorptie- of schaarsteproblemen wordt bepaald op basis van de zogeheten indicator toekomstige arbeidsmarktsituatie (ITA) van een opleiding ${ }^{5}$. Hierbij wordt per opleidingstype een confrontatie gemaakt van de verwachte vraag naar nieuwkomers en het verwachte aanbod. Het aanbod bestaat enerzijds uit de verwachte instroom in de periode 1989-1994 en anderzijds uit het aantal werklozen met dezelfde opleidingsachtergrond die in 1989 korter dan 1 jaar werkloos zijn (zie ook schema 2.1.). Door alleen uit te gaan van de werklozen die korter dan 1 jaar werkloos zijn, wordt verondersteld dat degenen die langer werkloos zijn niet concurreren op de arbeidsmarkt met de schoolverlaters van het desbetreffende opleidingstype. Tegenover dit aanbod staat aan de vraagzijde van de arbeidsmarkt de som van de uitbreidings- en de vervangingsvraag. De arbeidmarktindicator van opleidingen wordt behandeld in paragraaf 3.2. Een ongunstige arbeidsmarktindicator hoeft niet automatisch te betekenen dat schoolverlaters geconfronteerd zullen worden met werkloosheid, net zo $\mathrm{min}$ als dat er automatisch onvervulde vacatures in de personeelsvoorziening zullen ontstaan wanneer er een duidelijk vraagoverschot is. Wat de uiteindelijke consequenties zullen zijn van een vraag- of een aanbodoverschot, is mede afhankelijk van de marktpositie van de betreffende opleidingen en beroepsklassen, bijvoorbeeld van de vraag of de schoolverlaters kunnen uitwijken naar andere sectoren van de arbeidsmarkt, of van de substitutiemogelijkheden tussen opleidingstypen binnen een beroepsklasse. Paragraaf 3.3. gaat daarom in op de marktpositie van beroepsklassen. Nagegaan zal worden welke beroepsklassen een verhoogd risico hebben op knelpunten in de personeelsvoorziening. In paragraaf 3.4. staat de marktpositie van de opleidingen centraal. Daarbij zal aangegeven worden welke opleidingen een verhoogd risico hebben op absorptieproblemen en welke opleidingen in de positie verkeren om eventuele problemen af te wentelen op andere aanbodscategorieën.

\subsection{De arbeidsmarktperspectieven: vraag en aanbod geconfronteerd}

Wanneer het totaal aantal baanopeningen naar opleidingstype geconfronteerd wordt met het totale aanbod van het desbetreffende opleidingstype, dan levert dat een indicatie op van de arbeidsmarktperspectieven. Tabel 3.1. geeft aan welke opleidingen in dit opzicht naar

5. Zie voor een toelichting Wieling, 1990. 
verwachting de beste arbeidsmarktperspectieven voor de periode 1989-1994 hebben ${ }^{6}$.

Tabel 3.1. Opleidingen met gunstige arbeidsmarktperspectieven in de periode 1989-1994

$\begin{array}{lr}\text { LBO Vervoer \& Haven } & 0.84 \\ \text { MBO Economisch \& Administratief } & 0.91 \\ \text { WO Theologie } & 0.95 \\ \text { MBO Vervoer \& Haven \& Telecom } & 0.98 \\ \text { LBO Sociale Verzorging \& Horeca } & 0.99 \\ \text { HBO Theologie } & 1.00 \\ \text { HBO Medisch Laboratorium } & 1.00 \\ \text { HBO Economisch \& Administratief } & 1.00 \\ \text { MBO Politie \& Brandweer \& Defensie } & 1.01 \\ \text { MAVO en onderbouw HAVO \& VWO } & 1.01 \\ \text { MBO Medisch Laboratorium } & 1.02 \\ \text { MBO Bestuurlijk \& Recht \& Fiscaal } & 1.02 \\ \text { HBO Lucht- en Zeevaart \& Verkeer } & 1.04\end{array}$

De opleidingen met goede arbeidsmarktperspectieven zijn vooral terug te vinden in de volgende sectoren: Vervoer \& Haven, Economisch \& Administratief, Theologie en Medisch Laboratorium. Naar niveau bekeken zijn vooral de MBO- en HBO-opleidingen goed vertegenwoordigd. De opleiding LBO Vervoer \& Haven dankt haar gunstige arbeidsmarktperspectief aan zowel een relatief groot aantal baanopeningen als aan een relatief geringe uitstroom van schoolverlaters. De MBO- en HBO-opleidingen Economisch \& Administratief danken hun gunstige arbeidsmarktperspectieven vooral aan de hoge uitbreidingsvraag in de betreffende sector. Een relatief groot aantal baanopeningen is ook de voornaamste achtergrond voor de gunstige positie van de opleiding MBO Medisch Laboratorium. De opleidingen WO Theologie, LBO Sociale Verzorging \& Horeca, MBO Politie, Brandweer \& Defensie, MAVO en onderbouw HAVO \& VWO, MBO Bestuurlijk \& Recht \& Fiscaal en HBO Lucht-, Zeevaart \& Verkeer danken daarentegen hun gunstige perspectief vooral aan het feit dat ze een relatief geringe uitstroom kennen. Opvallend is dat de technische opleidingen (uitgezonderd het medisch laboratorium onderwijs) in dit rijtje ontbreken. Enerzijds is de uitbreidingsvraag voor deze studierichtingen met name op $\mathrm{HBO}$ - en WO-niveau relatief hoog. De vervangingsvraag is echter relatief laag, terwijl de instroom van schoolverlaters gemiddeld is. Daarom wordt van deze opleidingen geen extreem gunstig perspectief verwacht, maar een redelijk arbeidsmarktperspectief.

6. De waarde 1.05 geeft een evenwichtsituatie aan van vraag en aanbod, waarbij de frictiewerkloosheid op $5 \%$ is gesteld. 
In tabel 3.2. staan de opleidingen vermeld die relatief ongunstige arbeidsmarktperspectieven hebben. In de eerste plaats valt op dat aanbodoverschotten vooral dreigen plaats te vinden op HBO- en WO-niveau enerzijds en voor ongediplomeerden (alleen Basisonderwijs) anderzijds. Bedreigde opleidingssectoren zijn vooral de kunst en agrarische opleidingen. Een opvallende plaats in het rijtje wordt ingenomen door de opleiding HBO Technische Bedrijfskunde als enige meer technische opleiding. Haar slechte arbeidsmarktperspectief wordt vooral veroorzaakt door de relatief erg hoge uitstroom van schoolverlaters. Dat geldt ook voor de beide agrarische opleidingen, de opleiding MBO Sociaal \& Cultureel en WO Rechten \& Bestuurskunde. De opleidingen WO Kunstwetenschappen en WO Letteren danken hun slechte perspectief aan zowel een gering aantal baanopeningen als een relatief zeer hoge uitstroom. Dit makt hun positie ook extra kwetsbaar. Voor de opleidingen Basisonderwijs en HBO Kunst tenslotte geldt dat vooral de vraag naar deze typen schoolverlaters relatief sterk achterblijift.

Tabel 3.2. Opleidingen met ongunstige arbeidsmarktperspectieven in de periode 1989-1994

Opleidingstype arbeidsmarktindicator

\begin{tabular}{lr} 
WO Kunstwetenschappen & 2.62 \\
WO Letteren e.d. & 1.80 \\
HBO Agrarisch & 1.64 \\
WO Agrarisch & 1.64 \\
MBO Sociaal \& Cultureel & 1.63 \\
WO Rechten \& Bestuurskunde & 1.62 \\
HBO Technische Bedrijfskunde & 1.55 \\
Basisonderwijs & 1.52 \\
HBO Kunst & 1.49 \\
WO Sociale Wetenschappen & 1.48 \\
HBO Verpleging en Fysiotherapie & 1.47 \\
Bovenbouw HAVO \& VWO & 1.43 \\
LBO Beveiliging en Bewaking & 1.43 \\
\hline
\end{tabular}

\subsection{De marktpositie van beroepsklassen}

Opleidingen met goede arbeidsmarktperspectieven bleken in de vorige paragraaf vooral gevonden te worden in de volgende sectoren: Vervoer \& Haven, Economisch \& Administratief, Theologie en Medisch Laboratorium. Naar niveau bekeken bleken het vooral MBO- en HBOopleidingen te zijn. Beroepsklassen die grotendeels op deze opleidingen zijn aangewezen, zullen ook de meeste kans lopen op knelpunten in de personeelsvoorziening. Of deze knelpunten ook daadwerkelijk zullen optreden is afhankelijk van een aantal andere factoren. In deze paragraaf zullen een aantal factoren worden besproken die het risico op eventuele knelpunten versterken 
of juist verzwakken. Het gaat hierbij nadrukkelijk niet om risico-afweging voor aanbieders van arbeid, maar om risicofactoren voor vragers van arbeid. Het betreft met name de mate waarin een beroepsklasse afhankelijk is van schoolverlaters, de conjunctuurgevoeligheid, en het relatieve aanzien van een beroepsklasse ${ }^{7}$. Ook de eerder behandelde relatieve vervangingsvraag (tabel 2.4., onderste deel) kan overigens duiden op een risico-factor, althans voor zover ze betrekking heeft op een hoog verloop in de beroepsklasse. Een hoog verloop kan immers duiden op relatief onaantrekkelijke arbeidsomstandigheden.

Tabel 3.3. Beroepsklassen met een relatief hoog, respectievelijk laag aandeel werknemers jonger dan 30 jaar

Hoog aandeel jongeren

CBS beroepsklasse aandeel werknemers $<30$ jaar

$\begin{array}{lll}48 & \text { Winkelbedienden e.a. verkopers } & 0.53 \\ 58 & \text { Brandweer-, politiepersoneel e.d. } & 0.53 \\ 32 & \text { Secretaressen, typisten e.d. } & 0.52 \\ 06 / 07 & \text { Genees- en verpleegkundig personeel } & 0.52 \\ 54 & \text { Huishoudelijk en verz. pers. n.e.g. } & 0.50 \\ 77 & \text { Voedingsmiddelen/drankenbereiders } & 0.50 \\ 78 & \text { Tabaksbewerkers, -produktenmakers } & 0.49 \\ 34 & \text { Computerapparatuuroperateurs e.d. } & 0.48 \\ 60 & \text { Bedrijfsleiders land- en tuinbouw } & 0.48 \\ 33 & \text { Boekhouders, kassiers } & 0.46\end{array}$

Laag aandeel jongeren

CBS beroepsklasse

aandeel werknemers

$<30$ jaar

Leidinggevenden bij openb. bestuur $\quad 0.00$

Directeur/bedrijfsleider horeca $\quad 0.00$

Uitvoerende hoofdambtenaren $\quad 0.02$

Leidinggevenden excl. openb. best. $\quad 0.05$

Directeur/bedr.leiders groothandel $\quad 0.06$

Bedienaars van eredienst e.d. $\quad 0.09$

Leidinggevend produktiepersoneel $\quad 0.10$

Zelfstandige land- en tuinbouwers $\quad 0.12$

$\begin{array}{lll}43 & \text { Zelfst. winkeliers/detailhandelaren } & 0.12 \\ 11 & \text { Accountants } & 0.12\end{array}$

7. Met ingang van komend jaar is het de bedoeling dat naast de genoemde risico-factoren ook gekeken wordt naar de mate waarin het opleidingsaanbod voor een bepaalde beroepsklasse onderling substitueerbaar is. 
De uitstroom van schoolverlaters naar de arbeidsmarkt neemt in het begin van de jaren '90 af met zo'n 8\% (zie ook hoofdstuk 5, figuur 5.5.). Omdat leerlingen steeds langer onderwijs volgen is deze daling minder groot dan men op grond van demografische ontwikkelingen zou voorspellen. De vermindering van de uitstroom doet zich vooral voelen op de lagere onderwijsniveau's AVO en LBO, vanwege de verhoogde doorstroom naar vervolgonderwijs. Op deze niveau's bedraagt de daling van de uitstroom zo'n $30 \%$. Beroepsklassen die sterk afhankelijk zijn van de instroom van deze schoolverlaters lopen daarom grote kans op knelpunten in de personeelsvoorziening. In tabel 3.3. is aangegeven in welke beroepsklassen relatief veel mensen werkzaam zijn die jonger zijn dan 30 jaar, en welke beroepsklassen relatief weinig. Onder de beroepsklassen met een relatief hoog aandeel jongeren treft men relatief veel vrouwenberoepen (winkelpersoneel, secretaressen en typisten, genees- en verpleegkundig personeel, en huishoudelijk en verzorgend personeel). In de betreffende tien beroepsklassen is de helft of meer van het aantal werkzame personen jonger dan 30 jaar. In twee van deze beroepsklassen is ook sprake van een relatief hoge vervangingsvraag (zie tabel 2.4.): winkelpersoneel, en secretaressen en typisten. De beroepsklassen met een relatief laag aandeel van jongeren betreffen voornamelijk leidinggevende functies en zelfstandige beroepen.

Ook de arbeidszekerheid van een beroepsklasse kan een risico-factor zijn. Beroepsklassen waarvan de werkgelegenheid sterk fluctueert, verkeren in een nadelige situatie op de arbeidsmarkt. Beroepsklassen waarbij sprake is van een stabiele werkgelegenheidssituatie zijn daarentegen relatief aantrekkelijk voor het arbeidsaanbod. In tabel 3.4. is een overzicht gegeven van enerzijds de beroepsklassen die geconcentreerd zijn in sterk conjunctuurgevoelige sectoren en anderzijds van beroepsklassen die geconcentreerd zijn in sectoren waarvan de werkgelegenheidsontwikkeling relatief evenwichtig is geweest ${ }^{8}$. Sterk conjunctuurgevoelige beroepen zijn te vinden in de textiel- en kledingindustrie, de bouwnijverheid en de metaalindustrie. Voor de beroepsklasse uit de basismetaal (hoogovenarbeiders, walsers en vormers) doet zich daarbij het probleem voor dat ze bovendien met een relatief hoge vervangingsvraag wordt geconfronteerd. Beroepsklassen met een geringe conjunctuurgevoeligheid betreffen beroepen in de landbouw en visserij, de consumptie-industrie en de publieke sector: onderwijs, leger, overheid en openbaar vervoer.

8. De conjunctuurgevoeligheid van een sector $\mathrm{FI}_{\mathrm{b}}$ is berekend met behulp van een fluctuatieindex van de sectorale werkgelegenheidsontwikkeling, gebaseerd op de absolute afwijkingen van de trendmatige werkgelegenheidsontwikkeling tussen 1950 en 1988 (De Grip, Heijke en Dekker, 1989). De conjunctuurgevoeligheid van een beroepsklasse is vervolgens bepaald als het gewogen gemiddelde van de sectorale conjunctuurgevoeligheid. 
Tabel 3.4. Beroepsklassen met een relatief hoge, respectievelijk lage conjuctuurgevoeligheid $\left(\mathrm{FI}_{\mathrm{b})}\right.$

Hoge conjunctuurgevoeligheid

CBS beroepsklasse $\mathrm{FI}_{\mathrm{b}}$

$\begin{array}{ll}\text { Spinners, wevers, breiers, ververs } & 3.9 \\ \text { Schoenmakers; lederwarenmakers e.d. } & 3.3 \\ \text { Metselaars e.a. bouwvakarbeiders } & 3.3 \\ \text { Kleermakers, kostuumnaaisters e.d. } & 3.1 \\ \text { Schilders } & 3.0 \\ \text { Elektromonteurs, -reparateurs } & 2.7 \\ \text { Loodgieters, pijpfitters, lassers } & 2.7 \\ \text { Arbeiders n.e.g. } & 2.7 \\ \text { Smeden, gereedschapmakers e.d. } & 2.6 \\ \text { Hoogoven-, walsers, vormers e.d. } & 2.6\end{array}$

Lage conjunctuurgevoeligheid

\begin{tabular}{lll}
\hline CBS & Beroepsklasse & $\mathrm{FI}_{\mathrm{b}}$ \\
\hline & & \\
61 & Zelfstandige land- en tuinbouwers & 1.0 \\
64 & Vissers, jagers e.d. & 1.0 \\
69 & Beroepsmilitairen & 1.0 \\
13 & Leerkrachten & 1.0 \\
31 & Uitvoerende hoofdambtenaren & 1.0 \\
20 & Leidinggevenden bij openb. bestuur & 1.1 \\
78 & Tabaksbewerkers, -produktenmakers & 1.1 \\
36 & Conducteurs trein, tram, bus e.d. & 1.1 \\
62 & Agrarische arbeiders & 1.2 \\
77 & Voedingsmiddelen/drankenbereiders & 1.2 \\
\hline
\end{tabular}

De laatste risico-factor die hier wordt behandeld, betreft het relatieve aanzien van een beroepsklasse. Beroepsklassen onderscheiden zich van elkaar door het maatschappelijk prestige dat ze genieten (Sixma en Ultee, 1983). Men kan veronderstellen dat beroepen die een hoog aanzien hebben, ook een relatief gunstige positie innemen op de arbeidsmarkt: het beroep is dan erg gewild. Omgekeerd zullen beroepen met een laag aanzien waarschijnlijk minder aantrekkelijk zijn voor het arbeidsaanbod (tenzij dat gecompenseerd wordt door meer beloning e.d.). Het probleem doet zich nu voor dat het aanzien van een beroepsklasse sterk samenhangt met het beroepsniveau: hoe hoger het beroepsniveau, hoe hoger in het algemeen het aanzien. Voor het arbeidsaanbod geldt natuurlijk dat slechts beroepen van bepaalde niveau's binnen de range van mogelijkheden liggen. Voor iemand met een LBO-opleiding mag het beroep van accountant dan wel een hoog aanzien genieten, bereikbaar is het zeker niet, en het zal dan ook geen rol spelen 
in de afweging van mogelijke beroepsalternatieven. Dat geldt uiteraard wel voor de beroepsklassen op het functieniveau waarvoor men is opgeleid. In plaats van het beroepsprestige als zodanig, is het derhalve zinvoller om te kijken naar het relatieve aanzien van een beroepsklasse, dat wil zeggen het aanzien gecorrigeerd voor het functieniveau. Immers als het gaat om de marktpositie van een beroep, dan zal deze eerder worden bepaald door het relatieve aanzien, dan door het absolute aanzien.

Tabel 3.5. Beroepsklassen met een relatief laag, respectievelijk hoog aanzien

\section{Laag aanzien}

\begin{tabular}{llcc}
\hline CBS & beroepsklasse & $\begin{array}{c}\text { relatief } \\
\text { aanzien }\end{array}$ & $\begin{array}{c}\text { gewogen } \\
\text { functieniveau }\end{array}$ \\
\hline & & & 1.0 \\
99 & Arbeiders n.e.g. & -1.64 & 1.1 \\
56 & Wassers, persers e.d. & -1.59 & 1.3 \\
55 & Huisbewaarders, schoonmaakpersoneel & -1.54 & 2.4 \\
77 & Voedingsmiddelen/drankenbereiders & -1.39 & 2.1 \\
48 & Winkelbedienden e.a. verkopers & -1.38 & 1.3 \\
90 & Rubber- en plasticproductenmakers & -1.38 & 1.8 \\
73 & Houtzagers, papiermakers e.d. & -1.38 & 1.4 \\
89 & Glas-, aardewerkvormers e.d. & -1.38 & 1.0 \\
91 & Papierwaren- en kartonnagewerkers & -1.32 & 1.9 \\
80 & Schoenmakers; lederwarenmakers e.d. & & \\
\hline
\end{tabular}

Hoog aanzien

\begin{tabular}{llcc}
\hline CBS & beroepsklasse & $\begin{array}{c}\text { relatief } \\
\text { aanzien }\end{array}$ & $\begin{array}{c}\text { gewogen } \\
\text { functieniveau }\end{array}$ \\
\hline & & & 2.18 \\
20 & Leidinggevenden bij openb. bestuur & 2.13 & 6.4 \\
12 & Juristen & 2.08 & 6.0 \\
21 & Leidinggevenden excl. openb. best. & 1.72 & 6.0 \\
40 & Directeur/bedr.leiders groothandel & 1.56 & 4.6 \\
04 & Vliegtuig- en scheepsofficieren & 1.41 & 6.0 \\
09 & Economen & 1.25 & 6.1 \\
31 & Uitvoerende hoofdambtenaren & 1.18 & 6.0 \\
08 & Statistici, systeemanalisten e.d. & 1.15 & 5.7 \\
14 & Bedienaars van eredienst e.d. & 1.15 & 6.2 \\
11 & Accountants & & \\
\hline
\end{tabular}


In tabel 3.5. staat aangegeven welke beroepsklassen een relatief hoog aanzien hebben en welke beroepsklassen een relatief laag aanzien'. Tevens staat aangegeven wat het gemiddeld functieniveau is van de betreffende beroepsklasse. Deze niveauscores hebben betrekking op het voor een functie vereiste opleidingsniveau en zijn ontleend aan Huijgen (1989). De range loopt van 1 (ongeschoolde arbeid) tot 7 (academische arbeid). De beroepsklassen met een relatief laag aanzien hebben allemaal betrekking op ongeschoold of laaggeschoold werk. Met andere woorden, ondanks de correctie voor het functieniveau zijn het vooral de ongeschoolde en laaggeschoolde beroepen (met name in de industrie) die een relatief laag aanzien hebben. Het omgekeerde beeld wordt aangetroffen bij de functies met een relatief hoog aanzien: dit betreft vrijwel uitsluitend beroepsklassen op HBO- en WO-niveau. Van de beroepsklassen met een relatief laag aanzien zijn er twee die een vrij hoge vervangingsvraag kennen: de beroepsklasse van wassers en persers, en het winkelpersoneel.

Zet men de voorgaande risicofactoren nog eens op een rij, dan zijn er een aantal beroepsklassen die in meerdere opzichten als risicovol kunnen worden aangemerkt voor de vraagzijde van de arbeidsmarkt ${ }^{10}$. In de eerste plaats betreft dit het winkelpersoneel: hier is sprake van zowel een hoge vervangingsbehoefte, een hoge instroom van jongeren en een relatief laag aanzien. Voor de beroepsklasse van secretaressen \& typisten geldt een relatief hoge vervangingsvraag, gepaard aan een hoge instroom van jongeren. Voor de beroepsklasse van voedingsmiddelen- en drankenbereiders is sprake van een hoog aandeel van jongeren in de werkzame bevolking en een relatief laag aanzien. Voor de beroepsklassen van (industrie-)arbeiders en schoen- en lederwarenmakers is sprake van zowel een relatief laag aanzien als een hoge conjunctuurgevoeligheid. Voor de beroepsklasse van hoogovenarbeiders, walsers en vormers tenslotte is sprake van zowel grote conjunctuurgevoeligheid als een relatief hoge vervangingsvraag.

\subsection{De marktpositie van opleidingen}

Ook voor opleidingen geldt dat een aanbodoverschot niet automatisch leidt tot absorptiepro-

9. Het relatieve aanzien is berekend als het (gestandaardiseerde) residu bij de regressie van het aanzien van een beroepsklasse op het functieniveau. Het aanzien van de beroepsklasse is ontleend aan Sixma en Ultee (1983). Het functieniveau van een beroepsklasse is bepaald als het gewogen gemiddelde van het functieniveau van de onderliggende beroepsgroepen (Huijgen, 1989). Aangezien prestigescores op het niveau van beroepsgroepen vrijwel ontbreken, is hier noodgedwongen gebruik gemaakt van de grovere beroepsklasse-indeling.

10. Het is de bedoeling dat met ingang van komend jaar een samengestelde indicator zal worden berekend voor de marktpositie van beroepsklassen. 
blemen op de arbeidsmarkt, net zo $\mathrm{min}$ als dat een vraagoverschot voor een bepaalde opleidingscategorie automatisch betekent dat alle schoolverlaters uit die categorie werk zullen vinden. Het optreden van absorptieproblemen is sterk afhankelijk van de positie die een opleiding inneemt op de arbeidsmarkt. In dat opzicht kunnen een aantal risicofactoren worden onderscheiden: huidige werkloosheid, functieniveau en onderbenutting, en de uitwijkmogelijkheden op de arbeidsmarkt.

Tabel 3.6. Opleidingen met een hoge, respectievelijk lage werkloosheid (cijfers april 1990)

Hoge werkloosheid

Opleidingstype

$\%$

WO Kunstwetenschappen $\quad 32$

Basisonderwijs $\quad 28$

HBO Kunst $\quad 25$

$\begin{array}{ll}\text { WO Letteren e.d. } & 17\end{array}$

Bovenbouw HAVO \& VWO $\quad 17$

LBO Economisch \& Administratief $\quad 15$

WO Sociale Wetenschappen $\quad 14$

MAVO en onderbouw HAVO \& VWO 14

WO Agrarisch 13

MBO Sociaal \& Cultureel 13

HBO Sociaal \& Cultureel 13

Lage werkloosheid (minder dan 5\%)

MBO Politie \& Brandweer \& Defensie 0

HBO Politie \& Brandweer \& Defensie 0

MBO Bestuurlijk \& Recht \& Fiscaal

HBO Economisch \& Administratief 1

MBO Economisch \& Administratief 2

MBO Technisch \& Laboratorium 2

MBO Vervoer \& Haven \& Telecom 2

WO Farmacie 3

HBO Technisch 3

WO Econometrie \& Bedrijfskunde (ir) 3

MBO Agrarisch 3

MBO Medisch laboratorium 3

WO en HBO Theologie 3

HBO Medisch en Technisch laboratorium 3

HBO Lucht- en Zeevaart en Verkeer 3

WO Technisch 3

Bron: SOZAWE: bemiddelingsbestand zonder baan (BZB) 
De huidige werkloosheid is een belangrijke indicator van de marktpositie van een opleiding. In tabel 3.6. staat aangegeven welke opleidingen een hoge, respectievelijk lage werkloosheid kennen ${ }^{11}$. Opleidingen met een hoog percentage geregistreerde werklozen treft men zowel aan de onderkant als aan de bovenkant van het onderwijssysteem, maar niet of nauwelijks op MBOof HBO-niveau. Het zijn vooral de algemeen vormende opleidingen die zwaar door werkloosheid worden getroffen (Basisonderwijs, MAVO, HAVO, VWO) en voorts de 'zachtere' universitaire opleidingen (Kunstwetenschappen, Letteren, Sociale Wetenschappen). De MBO- en HBO-opleidingen kennen vrijwel allemaal een gunstige arbeidsmarktsituatie, met uitzondering van de sociaal-culturele sector en de kunstopleidingen.

$\mathrm{Nu}$ geeft het werkloosheidspercentage slechts een gedeeltelijk inzicht in de marktpositie van een opleiding. Zeker zo belangrijk is de vraag wat voor soort functies de schoolverlaters vervullen en of deze functies qua niveau aansluiten bij de in de opleiding verworven kwalificaties. In dit verband is gekeken naar de benuttingsproblematiek. Eerst is per opleiding het gemiddeld functieniveau bepaald van de beroepsgroepen waarin afgestudeerden van een opleiding werkzaam zijn. Dit functieniveau is ontleend aan Huijgen (1989). Vervolgens is per opleiding het percentage beroepsbeoefenaren bepaald dat een functie bekleedt onder het niveau van de opleiding $^{12}$. De gegevens zijn gebaseerd op de Arbeidskrachtentellingen van 1985. In tabel 3.7. staat vermeld welke opleidingen in 1985 relatief veel onderbenutting kennen en welke opleidingen relatief weinig. Enige voorzichtigheid bij de interpretatie is overigens geboden, omdat de niveau's in navolging van Huijgen (1989) bepaald zijn voor beroepsgroepen, een indeling die eigenlijk te grofmazig is. Hierdoor kan voor individuele opleidingen een systematische vertekening optreden, zowel naar boven als naar beneden.

De onderbenutting hangt sterk samen met het opleidingsniveau. Van alle beroepsbeoefenaren met een opleiding op uitgebreid lager niveau heeft $45 \%$ te maken met onderbenutting. Op middelbaar niveau bedraagt dit percentage $43 \%$, op semi-hoger niveau $24 \%$ en op hoger niveau $14 \%{ }^{13}$. Opleidingen met relatief veel onderbenutting komen voor op zowel LBO-, MBO- als HBO-niveau. Het percentage beroepsbeoefenaren dat een functie uitoefent beneden het niveau

11. Het werkloosheidspercentage is berekend als het aantal werklozen in 1990 (bron: SOZAWE, BZB) met opleiding $X$, gedeeld door de som van het aantal geregistreerde werklozen in 1990 en het aantal werkzame personen in 1989 met opleiding $X$, maal $100 \%$.

12. Voor WO-opleidingen ligt die grens in navolging van Huijgen (1989) bij niveau 5.5, voor HBO-opleidingen ligt de grens bij 4.5, voor MBO bij 3.5 en voor LBO bij 2.5.

13. Deze percentages wijken door iets andere opleidingsindelingen in geringe mate af van de cijfers van Huijgen (1989). 
van de opleiding bedraagt voor deze opleidingen 50 tot $90 \%$. Sectoren waar veel onderbenutting voorkomt zijn Vervoer \& Haven, Beveiliging \& Bewaking (incl. politie, brandweer etc) en Sociale Verzorging. Opvallende uitzonderingen in het rijtje vormen HBO Economisch \& Administratief en HBO Technisch Laboratorium.

Tabel 3.7. Opleidingen met veel respectievelijk weinig onderbenutting

Veel onderbenutting

Opleidingstype

onderbenutting

gemiddeld

$\%$

functie-niveau

LBO Beveiliging \& Bewaking

89

LBO Vervoer \& Haven

85

2.4

MBO Politie \& Brandweer \& Defensie

79

2.2

LBO Sociale Verzorging \& Horeca

67

MBO Vervoer \& Haven \& Telecom

63

2.4

HBO Politie \& Brandweer \& Defensie

62

3.3

MBO Sociale Verzorging

61

HBO Economisch \& Administratief

56

HBO Technisch Laboratorium

53

49

3.3

4.5

4.8

Bovenbouw HAVO \& VWO

3.8

Weinig onderbenutting

Opleidingstype

onderbenutting

gemiddeld

$\%$

functie-niveau

WO Farmacie

WO Dier- \& Genees- \& Tandheelkunde

6.8

HBO Verpleging \& Fysiotherapie e.d.

WO Docentenopleidingen

WO Letteren e.d.

WO Wiskunde \& Natuurwetenschappen

HBO Kunst

4

4

5.2

HBO Docentenopleidingen

6

7

6.4

$9 \quad 6.2$

MBO Medisch Laboratium

6.5

$11 \quad 5.3$

HBO Theologie

12

5.8

4.2

5.7

Bij de opleidingen met relatief weinig onderbenutting treft men vooral WO- en HBO-opleidingen. Het gaat met name om opleidingen die voorbereiden op een geprofessionaliseerde deelmarkt: gezondheidszorg, religie en onderwijs. Dit zijn deelmarkten waar een sterke regulering bestaat met betrekking tot beroepsintrede: concurrentie vanuit andere aanbodscategorieën is bij wet 
verboden. De betreffende opleidingen hebben in dat opzicht een sterke marktpositie, zij het dat ze wel kwetsbaar zijn voor kwantitatieve schommelingen in de vraag-aanbod verhoudingen (zie de hoge werkloosheidpercentages voor WO Letteren in tabel 3.6.).

Tabel 3.8. Opleidingen met geringe respectievelijk grote uitwijkmogelijkheden op aansluitend functieniveau

Geringe uitwijkmogelijkheden

\begin{tabular}{ll} 
Opleidingstype $\quad$ GH \\
\hline
\end{tabular}

$\begin{array}{ll}\text { LBO Beveiliging \& Bewaking } & 0.21 \\ \text { LBO Vervoer \& Haven } & 0.29 \\ \text { MBO Politie \& Brandweer \& Defensie } & 0.38 \\ \text { WO Docentenopleidingen } & 0.47 \\ \text { HBO Theologie } & 0.51 \\ \text { MBO Ziekenverzorging } & 0.51 \\ \text { LBO Sociale Verzorging \& Horeca } & 0.54 \\ \text { WO Dier- \& Genees- \& Tandheelkunde } & 0.55 \\ \text { WO Theologie } & 0.55 \\ \text { HBO Politie \& Brandweer \& Defensie } & 0.59\end{array}$

Grote uitwijkmogelijkheden

Opleidingstype

GH

$\begin{array}{ll}\text { HBO Technisch } & 0.95 \\ \text { WO Technisch } & 0.95 \\ \text { HBO Technische Bedrijfskunde } & 0.91 \\ \text { WO Wiskunde \& Natuurwetenschappen } & 0.91 \\ \text { HBO Agrarisch } & 0.90 \\ \text { WO Informatica, Economie, Bedrijfsk. } & 0.90 \\ \text { WO Agrarisch } & 0.89 \\ \text { MBO Technisch \& Laboratorium } & 0.86 \\ \text { WO Econometrie \& Bedrijfskunde (ir) } & 0.86 \\ \text { MBO Economisch \& Administratief } & 0.86\end{array}$

In zo'n geval is het belangrijk om te weten welke uitwijkmogelijkheden schoolverlaters hebben op de arbeidsmarkt. Een opleiding die veel uitwijkmogelijkheden kent is minder kwetsbaar voor schommelingen op de arbeidsmarkt dan een opleiding die helemaal geen uitwijkmogelijkheden heeft. Voor elke opleiding is daarom nagegaan hoe groot de spreiding is over beroepsklassen. Als spreidingsmaatstaf is gekozen voor de Gini-Hirschmann coëfficiënt, een maatstaf die de waarde 0 aanneemt wanneer alle personen met een bepaalde opleidingsachtergrond geconcen- 
treerd zijn in één beroep, en de waarde 1 wanneer deze personen gelijkmatig gespreid zijn over alle beroepsklassen (zie De Grip, Heijke en Dekker, 1989). De berekeningen zijn uitgevoerd op basis van de Arbeidskrachtentellingen van 1985 en hebben betrekking op de spreiding over beroepsklassen op aansluitend functieniveau. Dat wil zeggen dat uitwijkmogelijkheden naar lagere functies buiten beschouwing zijn gelaten: hier is immers geen sprake van 'echte' alternatieven. Het is van belang om op te merken dat de gehanteerde maatstaf betrekking heeft op de gerealiseerde uitwijkmogelijkheden en niet op de potentiële.

Opleidingen met geringe uitwijkmogelijkheden komen voor op alle opleidingsniveau's. Het betreft vooral opleidingen voor (semi-)geprofessionaliseerde sectoren, zoals bewaking, gezondheidszorg, onderwijs en religieuze instellingen. Opleidingen met relatief veel uitwijkmogelijkheden betreffen met name de technische, de agrarische en de economischadministratieve opleidingen op HBO- en WO-niveau.

Zet men de voorgaande gegevens nog eens op een rij, dan lijkt het volgende beeld te ontstaan ${ }^{14}$. In de eerste plaats is er een groep opleidingen te onderscheiden die zich richten op (semi-)geprofessionaliseerde deelmarkten. Kenmerkend voor deze opleidingen is dat ze in hun eigen sector weinig concurrentie ondervinden van andere opleidingen, maar anderzijds weinig uitwijkmogelijkheden hebben naar andere sectoren of lagere functies. Afhankelijk van de vraagaanbod verhoudingen op hun deelmarkt betreft het opleidingen met een goede arbeidsmarktpositie (bijvoorbeeld WO Geneeskunde of Farmacie, WO en HBO Theologie) of juist opleidingen met een relatief zwakke arbeidsmarktpositie (bijvoorbeeld WO Letteren). Een tweede groep opleidingen die onderscheiden kan worden betreft enkele opleidingen die zich richten op het hogere segment van de arbeidsmarkt. Deze opleidingen worden gekenmerkt door een zeer goede arbeidsmarktpositie: de werkloosheid is zeer laag, er is relatief weinig sprake van onderbenutting en men heeft een relatief groot aantal uitwijkmogelijkheden. Het betreft hier vooral universitaire opleidingen, zoals WO Technisch, WO Wiskunde \& Natuurkunde, en WO Economie, Econometrie \& Bedrijfskunde. Een derde groep van opleidingen heeft betrekking op de vakdeelmarkten. Hier kunnen de technische, de agrarische en de laboratorium opleidingen op MBO- en HBO-niveau toe worden gerekend. De werkloosheid onder deze opleidingen ligt bijzonder laag, de onderbenutting is relatief laag en de uitwijkmogelijkheden zijn vrij groot. Tenslotte kan men een groep van opleidingen onderscheiden die aangewezen is op het onderste segment van de arbeidsmarkt: de uitwijkmogelijkheden zijn hier bijzonder groot, maar dat komt omdat voor de meeste functies geen specifieke kwalificaties worden gevraagd. Het feit dat de onderbenuttingspercentages meevallen heeft te maken met het optreden van bodemeffecten.

14. Het is de bedoeling dat met ingang van komend jaar de marktpositie van opleidingen met een samengestelde indicator wordt beschreven. 
$-30-$

De slechte arbeidsmarktpositie van deze opleidingen uit zich daarom vooral in een hoge werkloosheid. Tot deze laatste groep van opleidingen kunnen de algemeen voortgezette opleidingen, het basisonderwijs en enkele LBO-opleidingen gerekend worden. 


\section{ONTWIKKELINGEN IN DE KWALIFICATIESTRUCTUUR EN DE STRUCTUUR VAN DE WERKGELEGENHEID}

\subsection{Inleiding}

In dit hoofdstuk wordt nagegaan hoe de kwalificatiestructuur van de schoolverlaters zich heeft ontwikkeld tussen 1979 en 1988 en wat de prognoses zijn voor de periode tot 1994. Voorts wordt nagegaan hoe de werkgelegenheidstructuur veranderd is in de periode 1979-1989, en welke ontwikkelingen zich hierin naar verwachting zullen voordoen in de prognoseperiode 19891994. Paragraaf 4.3. gaat in op de verschuivingen in de beroepenstructuur, paragraaf 4.4. behandelt de veranderingen in de opleidingsstructuur.

\subsection{De ontwikkeling van de kwalificatiestructuur}

De kwalificatiestructuur van de beroepsbevolking is een belangrijke determinant van de technologische ontwikkeling. Enerzijds bepaalt de scholingsgraad van de beroepsbevolking in sterke mate het innovatievermogen van de samenleving, anderzijds is ze ook een belangrijke determinant voor de snelheid waarmee technologische ontwikkelingen kunnen worden doorgevoerd. Voor de ontwikkeling in de kwalificatiestructuur van de beroepsbevolking is in het bijzonder van belang op welke wijze de uitstroom van schoolverlaters zich ontwikkelt. Figuur 4.1. geeft aan hoe de gediplomeerde uitstroom zich ontwikkeld heeft qua niveau in de periode 1979-1988 en wat de prognoses zijn voor de periode 1988-1994. De cijfers hebben uitsluitend betrekking op de gediplomeerde uitstroom, omdat voor de periode 1979-1988 gegevens over het hoogst behaalde onderwijsdiploma van ongediplomeerden ontbreken. De ongediplomeerden worden hier derhalve binnen elk onderwijsniveau buiten beschouwing gelaten. Aangezien de cijfers van de geprognosticeerde uitstroom en de beschikbare gegevens over de gerealiseerde uitstroom niet helemaal met elkaar overeenkomen, ligt bij de beschrijving het accent op de trendmatige ontwikkeling ${ }^{15}$.

$\mathrm{Na}$ een lichte teruggang in het begin van de jaren ' 80 stijgt het totaal aantal gediplomeerde schoolverlaters weer tot 1988. In totaal neemt in deze periode het aantal gediplomeerde schoolverlaters toe met $12 \%$. De grote verliezers in de periode 1979-1988 zijn de lagere trap van het AVO (-65\%), de hogere trap van het AVO (-35\%) en het LBO (-25\%). De gediplomeer-

15. Voor het jaar 1988-1989 worden zowel historische cijfers gepresenteerd, ontleend aan de Onderwijsmatrices van het CBS, als prognoses, ontleend aan de SKILL-raming 1990. Beide cijfers komen niet geheel overeen: met name wordt het aantal schoolverlaters op $\mathrm{MBO}-$ niveau in de prognoses onderschat. 
de uitstroom vanuit het WO verdriedubbelt bijna in deze periode. Met name in het studiejaar 1987-1988 stijgt de uitstroom van dit opleidingstype explosief. Ook het MBO is een duidelijke groeicategorie met een groei van $85 \%$ in de periode 1979-1988. De uitstroom van het HBO stijgt in diezelfde periode met $14 \%$. Uitgerekend voor dit opleidingstype wordt voor de prognoseperiode 1988-1994 een groei voorspeld van $36 \%$. Bij alle overige opleidingstypen neemt de totale gediplomeerde uitstroom af, vooral bij het LBO $(-36 \%)$, de lagere trap van het AVO $(-26 \%)$ en de hogere trap van het AVO (-17\%). Bij deze drie opleidingstypen wordt de dalende trend uit de jaren ' 80 dus voortgezet. Voor het MBO $(-8 \%)$ en het WO $(-5 \%)$ wordt voorspeld dat het relatieve aandeel in de uitstroom constant blijft (de totale gediplomeerde uitstroom neemt af met $8 \%$ ).

Figuur 4.1. Gediplomeerde uitstroom per opleidingsniveau 1979-1994 (cumulatief)

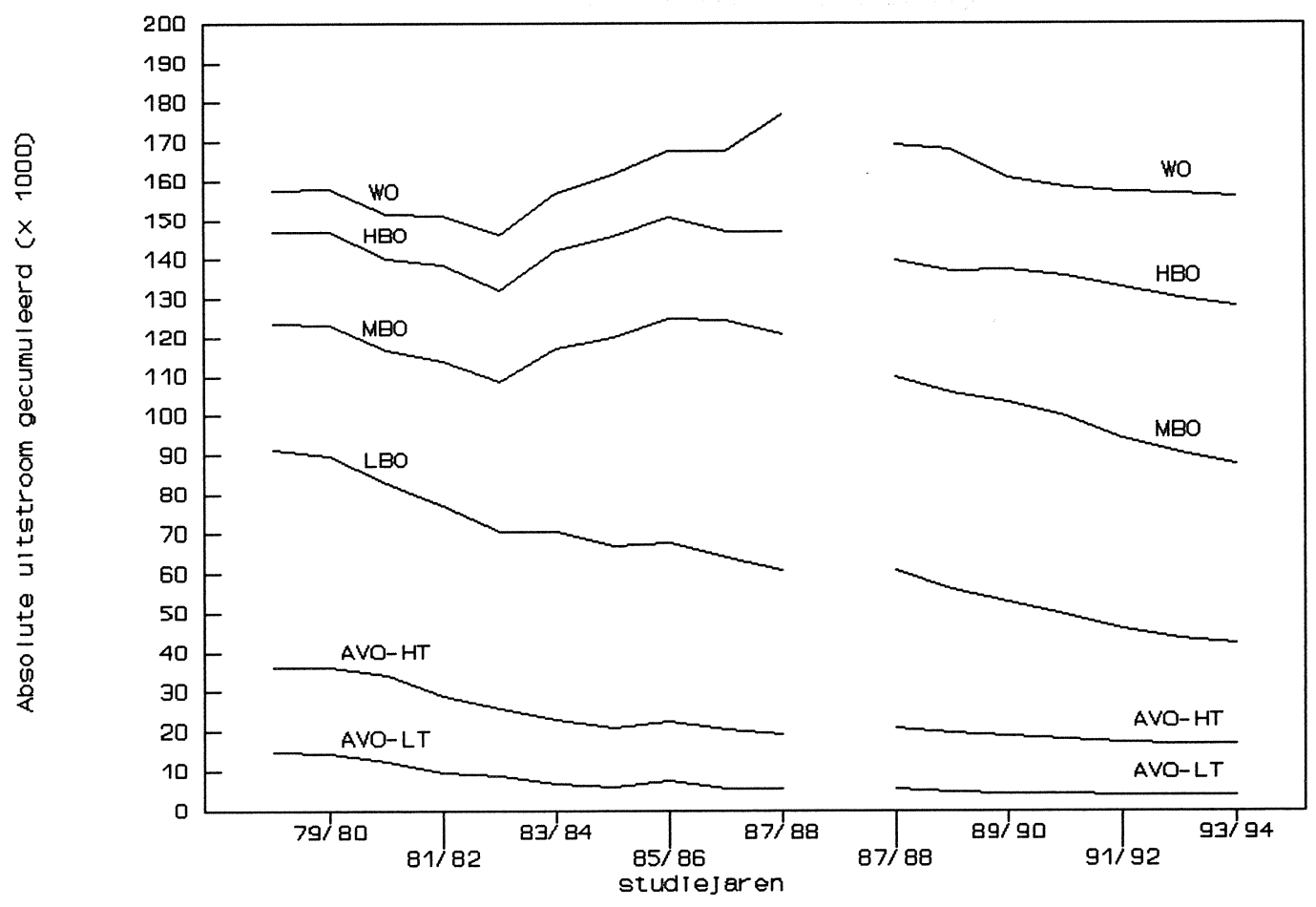

De ontwikkeling van de uitstroom van hoger opgeleiden komt nog wat scherper naar voren wanneer we kijken naar de ontwikkeling van het aandeel van deze groep in de totale gediplomeerde uitstroom. In figuur 4.2. komt duidelijk naar voren dat het aandeel van de hoger opgeleiden gedurende de gehele periode toeneemt: in de periode 1979 tot 1988 met $10 \%$ en in 
de periode daarna met $9 \%$. De groei in de eerste periode komt vooral voor rekening van het WO, de groei in de tweede periode komt voor rekening van het HBO. Voor 1994 wordt voorspeld dat $44 \%$ van de gediplomeerde schoolverlaters afkomstig is van HBO of WO. Dit betekent een verdubbeling vergeleken met de situatie van 1979. Of een dergelijk aantal hoger opgeleiden ook volledig opgenomen kan worden door de markt, is maar de vraag. In hoofdstuk 3 is reeds aangegeven dat vooral de hogere opleidingen te maken hebben met ongunstige arbeidsmarktperspektieven. In de periode 1989-1994 bestaat naar verwachting $27 \%$ van de totale gediplomeerde én ongediplomeerde uitstroom uit hoger opgeleiden (16\% HBO en $11 \%$ WO). Maar van het totaal aantal jobopeningen is slechts $18 \%$ expliciet bestemd voor hoger opgeleiden, waarvan $14 \%$ voor $\mathrm{HBO}$-ers en $4 \%$ voor WO-ers.

Figuur 4.2. Ontwikkeling aandeel hoger opgeleiden in de gediplomeerde uitstroom in de periode 19791994

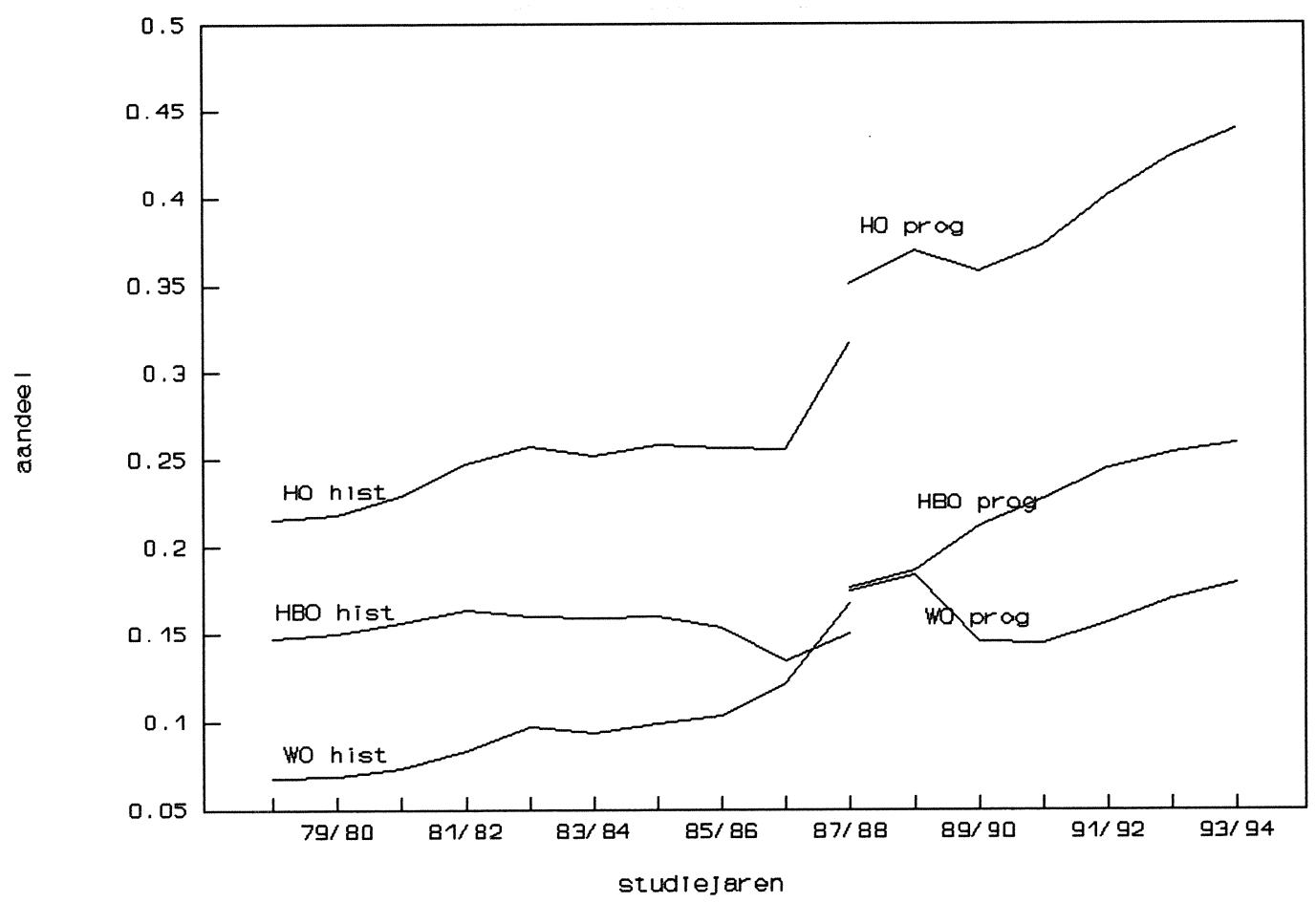

Voor de scholingsgraad van de beroepsbevolking is eveneens van belang hoeveel mensen de arbeidsmarkt betreden zonder enige beroepskwalificatie. Uit figuur 4.1. kon reeds afgelezen worden dat deze categorie schoolverlaters (AVO lagere en hogere trap plus het LBO) in omvang 
$-34-$

sterk is afgenomen. In 1979 had meer dan de helft van alle gediplomeerde schoolverlaters ten hoogste een AVO- of LBO-opleiding. In 1988 is het aandeel van deze groep in de totale uitstroom van gediplomeerde schoolverlaters afgenomen met $24 \%$. In de periode $1988-1994$ neemt dit aandeel verder af met $9 \%$. Uiteraard hangt dit sterk samen met de groei van het hoger onderwijs zoals weergegeven in figuur 4.2. Daarnaast is echter ook in de uitstroom van het voortgezet onderwijs zelf het aandeel van schoolverlaters zonder beroepskwalificatie afgenomen (zie figuur 4.3.).

Het aandeel van schoolverlaters uit het $\mathrm{MBO}, \mathrm{KMBO}$ of leerlingwezen binnen de totale gediplomeerde uitstroom van het voortgezet onderwijs is in de periode $1979-1988$ met $25 \%$ toegenomen (figuur 4.3.). Voor de periode 1988-1994 wordt voor het MBO een verdere groei van dit aandeel verwacht van 7\%. Voor het leerlingwezen en het KMBO ontbreken dergelijke prognoses helaas. Als algemene conclusie kan worden getrokken dat de scholingsgraad van de gediplomeerde uitstroom naar de arbeidsmarkt sterk is toegenomen, enerzijds door de groei van het hoger onderwijs en anderzijds door de afname van schoolverlaters met uitsluitend een AVOof LBO-opleiding.

Figuur 4.3. Ontwikkeling aandeel MBO en LLW/KMBO in de uitstroom van het VO in de periode 19791994

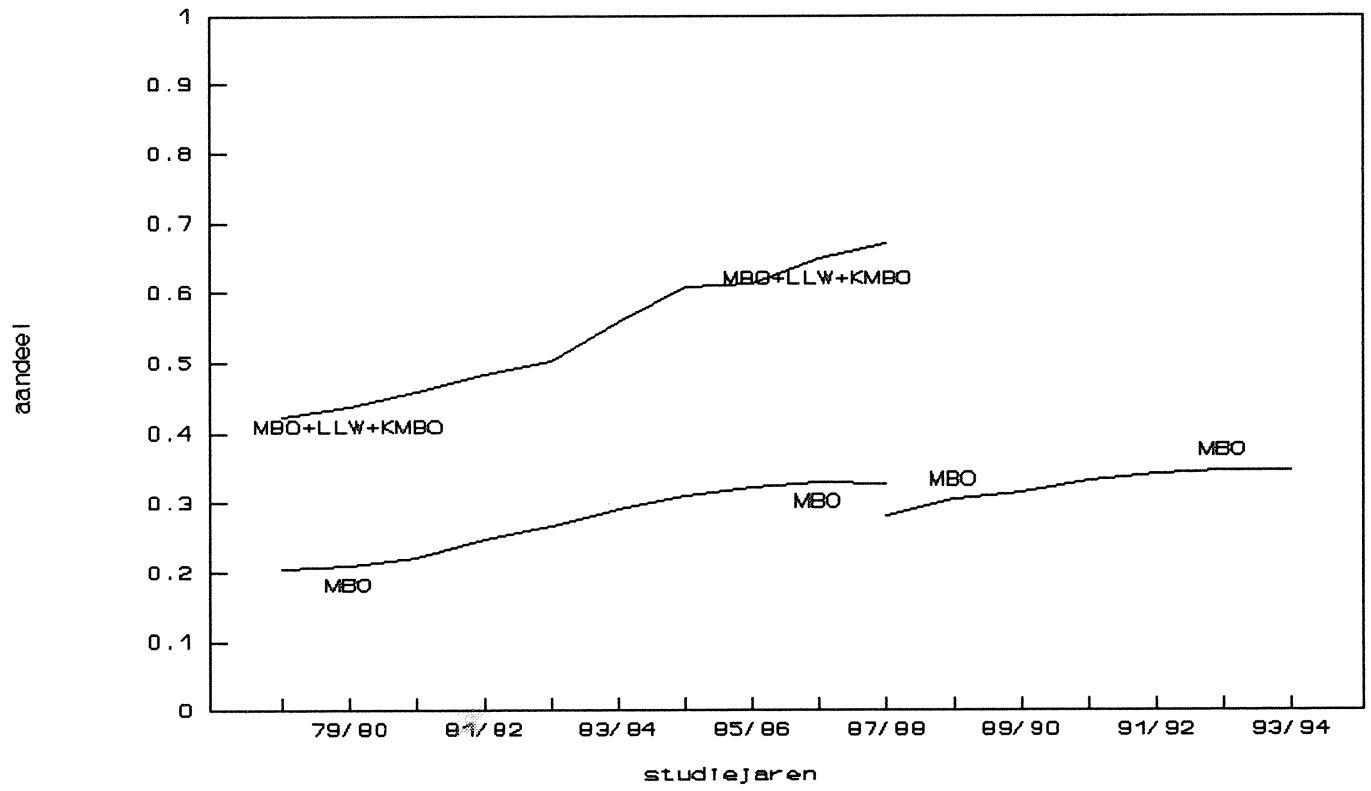


Voor de scholingsgraad van de beroepsbevolking is niet alleen de hoogte van het bereikte onderwijsniveau van belang, maar ook de richting van de gevolgde opleiding. In figuur 4.4. staat aangegeven hoe het aandeel van technisch opgeleiden zich ontwikkeld heeft in de uitstroom van respectievelijk het MBO en het hoger onderwijs. Dit aandeel is voor beide opleidingsniveau's zeer constant: voor het MBO schommelt dit rond de $22 \%$ en voor het hoger onderwijs rond de $25 \%$. De conclusie luidt dat het aandeel van middelbaar en hoger technisch opgeleiden in de uitstroom weliswaar toeneemt, maar dat dit uitsluitend te danken is aan de groei van het MBO en het hoger onderwijs. Binnen deze onderwijsniveau's is de relatieve uitstroom van technisch opgeleiden zeer constant. Voor de behoefte op de arbeidsmarkt lijkt deze uitstroom in totaliteit beschouwd maar nauwelijks voldoende. Het percentage middelbaar en hoger technisch opgeleiden in de totale (gediplomeerde én ongediplomeerde) uitstroom bedraagt respectievelijk $13 \%$ en $5 \%$. Het relatieve aandeel binnen het totaal aantal jobopeningen voor deze twee categorieën bedraagt respectievelijk 12 en $4 \%$.

Figuur 4.4. Ontwikkeling aandeel technisch opgeleiden binnen uitstroom MBO en hoger onderwijs in de periode 1979-1994

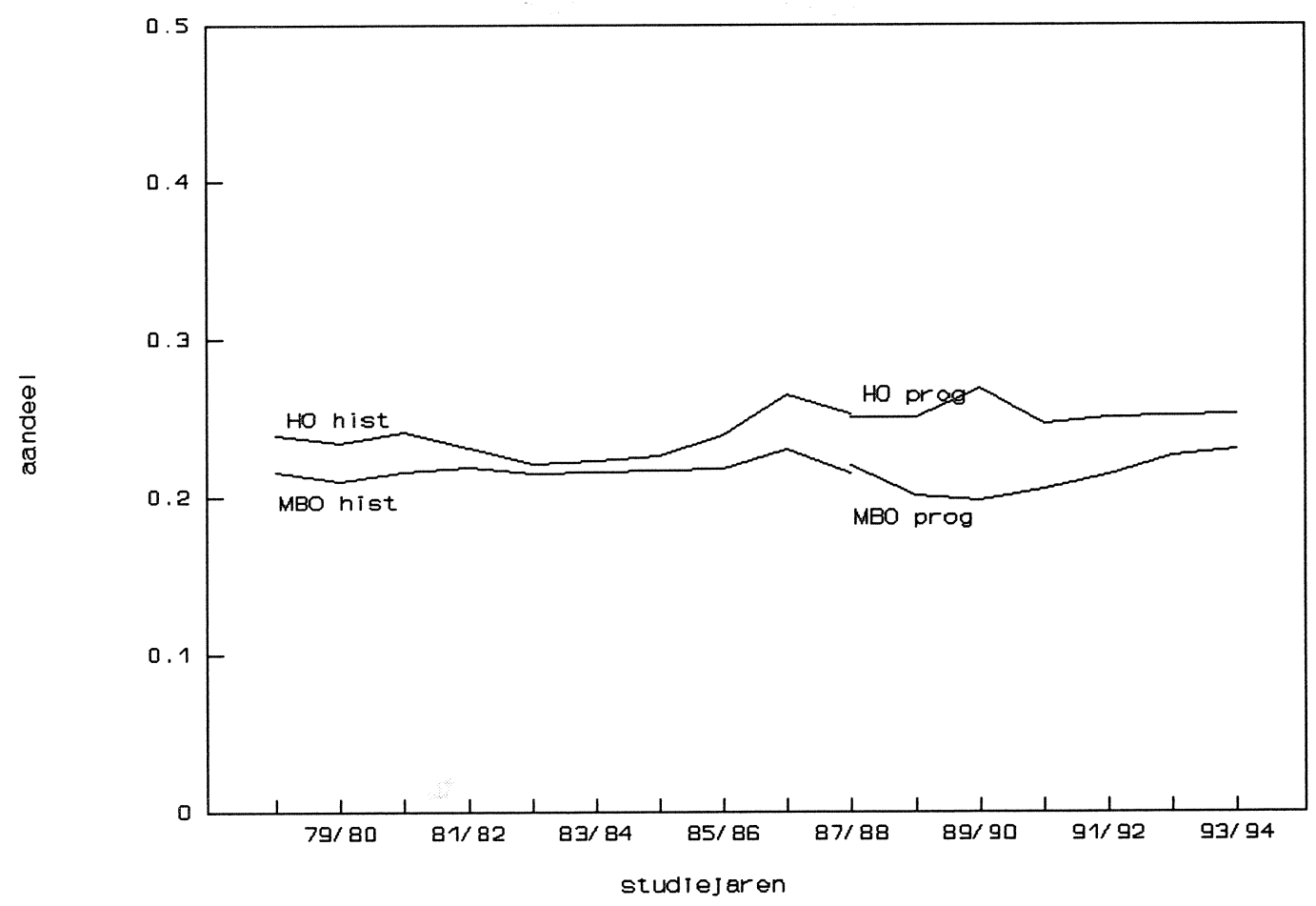




\subsection{Veranderingen in de beroepenstructuur}

In hoofdstuk 2 is reeds aangegeven hoe de werkgelegenheid zich naar sector heeft ontwikkeld tussen 1979 en 1989. Voorts zijn de verwachte ontwikkelingen gepresenteerd voor de periode 1989-1994. Daaruit kwam naar voren dat de recessie in het begin van de jaren ' 80 met name een ongunstig effect heeft gehad op de textiel- en kledingindustrie, de hout- en bouwmaterialenindustrie en de bouwnijverheid. De kwartaire sector, en met name de medische en veterinaire diensten en de overige kwartaire diensten, liet in deze periode juist een groei van de werkgelegenheid zien. In de tweede helft van de jaren ' 80 bleken de volgende sectoren sterk te profiteren van de economische groei: overige tertiaire diensten en woningbouw, de hout- en bouwmaterialenindustrie, de handel, de bouwnijverheid en de papier- en grafische industrie. Voor de prognoseperiode wordt voor de voedings- en genotmiddelenindustrie, de textiel- en kledingindustrie, en landbouw en visserij een lichte daling verwacht van het aantal werkzame personen. Groeisectoren zijn de handel, overige tertiaire diensten en woningbouw, het bank- en verzekeringswezen, de chemische industrie, de transportsector, en de kwartaire sector.

Met behulp van een shift-share analyse is nagegaan op welke wijze de beroepenstructuur in de drie onderscheiden perioden zich ontwikkelt (zie ook de Grip, 1987 en Teulings en Webbink, 1990). Daarbij kan een drietal effecten worden onderscheiden. Ten eerste is er mogelijk sprake van een sectorstructuureffect, dat wil zeggen: de werkgelegenheid in een beroepsklasse kan veranderen als gevolg van een verandering in de totale werkgelegenheid in de sectoren waarin de desbetreffende beroepsbeoefenaren werkzaam zijn. Ten tweede kan het beroepenstructuureffect onderscheiden worden. Hierbij gaat het om de groei of krimp van de werkgelegenheid in een beroepsklasse als gevolg van een toe- of afnemend aandeel van de desbetreffende beroepsklasse in de bedrijfssectoren waar men werkzaam is. Ten derde is er een interactieeffect mogelijk. Daarbij gaat het bijvoorbeeld om de groei van de werkgelegenheid als gevolg van de combinatie van een toename van het werkgelegenheidsaandeel van de beroepsklasse in een bepaalde sector en de toename van de totale werkgelegenheid in deze sector. Tabel 4.1. geeft aan hoe groot de totale verandering is geweest in de beroepenstructuur ${ }^{16}$, welk deel hiervan moet worden toegeschreven aan het sector(structuur)effect, welk deel aan het beroepen(structuur)effect en welk deel aan een interactie-effect. Daarbij wordt een onderscheid gemaakt in drie perioden.

16. Deze is gedefinieerd als de som van de absolute verschuivingen in het aandeel van een beroepsklasse in de totale werkgelegenheid. 
Tabel 4.1. Relatieve belang van het beroepenstructuur-, het sectorstructuur- en het interactie-effect

\begin{tabular}{lrrrr}
\hline & $\begin{array}{c}\text { saldo } \\
\text { totaaleffect }\end{array}$ & sectoreffect & beroepeffect & interactie-effect \\
\hline $1979-1985$ & 13.5 & 10.1 & 8.8 & 1.4 \\
$1985-1989$ & 8.6 & 5.7 & 6.2 & 0.6 \\
$1989-1994$ & 6.1 & 2.8 & 5.1 & 0.3 \\
\hline
\end{tabular}

In tabel 4.1. worden de absolute waarden van de onderscheiden verschuivingen in de werkgelegenheidsaandelen over alle beroepsklassen gesommeerd. Opvallend is de verschuiving in de algehele dynamiek. Naar verwacht zullen de totale verschuivingen in de werkgelegenheidsstructuur naar beroepsklasse in de eerste helft van de jaren '90 aanmerkelijk geringer zijn dan in de jaren '80. Daarbij moet wel bedacht worden dat het voor de periode 1989-1994 en deels ook de periode 1985-1989 gaat om prognosecijfers. Door de prognosemethodiek, waarbij in het geval van niet-significante ontwikkelingen in de analyseperiode, voor de prognoseperiode wordt uitgegaan van constante aandelen treedt een onderschatting op van de totale dynamiek. De verschuivingen in de eerste helft van dit decennium waren het grootst. De achterliggende structuurverschuivingen zijn overigens groter dan men uit de saldo totaaleffecten kan opmaken, omdat beroep- en sectoreffecten elkaar deels compenseren. De som van beroep- en sectoreffecten is voor elke periode beduidend groter dan het saldo totaal-effect. Afgezien van de prognoseperiode zijn sector- en beroepeffecten vrijwel aan elkaar gelijk. Het interactie-effect is in alle gevallen zeer gering.

Ten einde een meer specifiek beeld te krijgen van de onderscheiden effecten voor bepaalde beroepsklassen, wordt in figuur 4.5. een beeld geschetst van de verschuivingen die ten grondslag hebben gelegen aan de werkgelegenheidsgroei van de tien beroepsklassen, waarvoor voor de periode 1989-1994 de grootste (absolute) werkgelegenheidsgroei wordt verwacht (vergelijk tabel 2.2.).

Het sectoreffect blijkt slechts bij enkele beroepsklassen tot een opmerkelijke verschuiving van het werkgelegenheidsaandeel te leiden. Een positief sectoreffect doet zich voor bij het winkelpersoneel (code 48), de zelfstandige winkeliers (code 43), het genees- en verpleegkundig personeel (code 06/07) en de boekhouders, kassiers e.d. (code 33). Opmerkelijke negatieve sectoreffecten doen zich bij de hier in beeld gebrachte beroepsklassen niet voor. 
Figuur 4.5. Sector-, beroep- en interactie-effecten voor sterkste groeiberoepen 1989 - 1994 (gemeten in \%-punt verschuivingen)

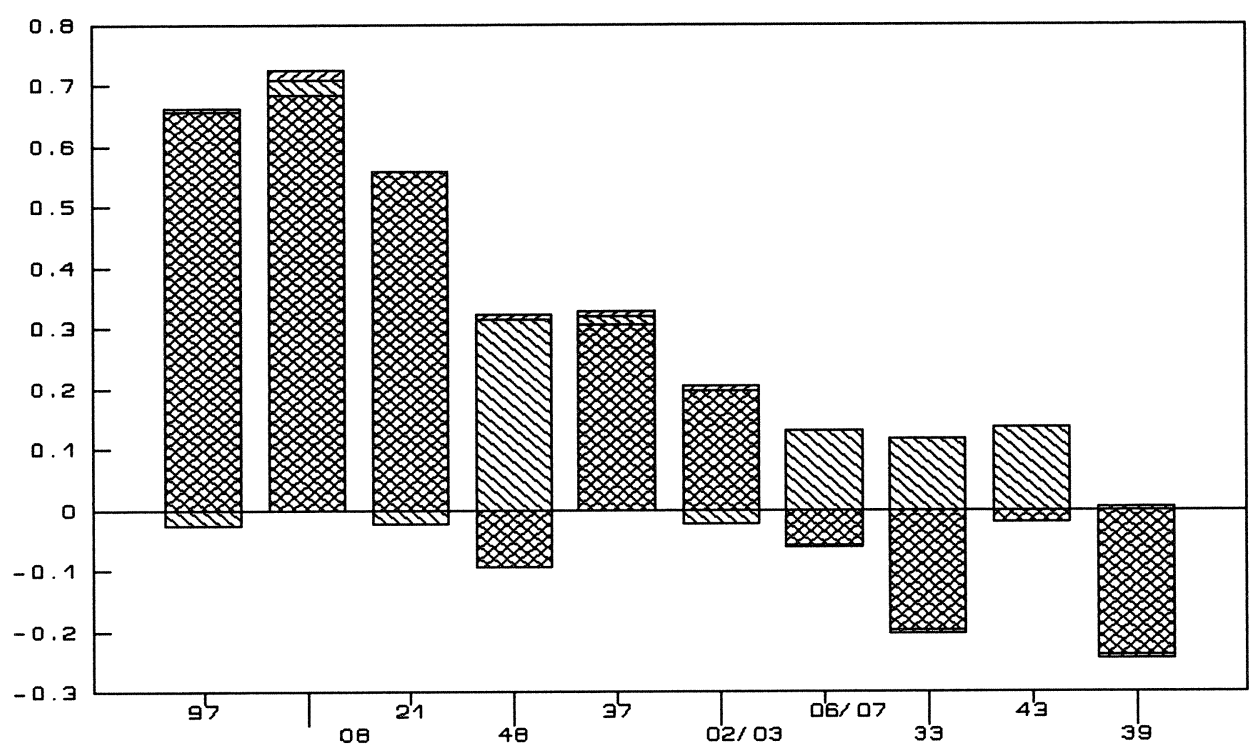

bercepeffect

Een negatief beroepeffect zien we bij de boekhouders, kassiers e.d. (code 33) en de (diverse) administratieve functies (code 39). Het gaat om grote beroepsklassen met weliswaar een grote werkgelegenheidstoename in absolute zin, maar met een minder dan gemiddelde procentuele werkgelegenheidsgroei, dat wil zeggen een dalend werkgelegenheidsaandeel. Ook voor het winkelpersoneel (code 48) en het genees- en verpleegkundig personeel (code 06/07) wordt een negatief beroepeffect verwacht. Een sterk positief beroepeffect wordt daarentegen verwacht voor de beroepsklassen laders, lossers e.d. (code 97), de automatiseringsdeskundigen (code 8) en de leidinggevenden, exclusief openbaar bestuur (code 21). Ook voor het postdistributiepersoneel (code 37) en de architecten, ingenieurs en tekenaars (code 02/03) doet zich naar wordt verwacht een duidelijk positief beroepeffect voor. De interactie-effecten zijn bij alle tien beroepsklassen klein tot zeer klein.

\subsection{Veranderingen in de opleidingsstructuur}

Ook voor de onderscheiden opleidingstypen is het mogelijk een nader beeld te geven van de verschillende componenten van de verschuivingen van de werkgelegenheidsaandelen. Daarbij worden opnieuw een drietal effecten onderscheiden. Ten eerste is er mogelijk sprake van een 
beroep/sector(structuur)effect dat uitdrukking geeft aan de verschuivingen in de werkgelegenheidsaandelen die veroorzaakt worden door verschuivingen in de beroepen- en of sectorstructuur. Ten tweede kan er sprake zijn van een opleiding(structuur)effect: de verschuivingen in het werkgelegenheidsaandeel als gevolg van verschuivingen in het opleidingsaandeel in de werkgelegenheid in bepaalde beroep/sector combinaties.

Tabel 4.2. geeft een beeld van de totale verschuiving in de opleidingsstructuur van de werkgelegenheid en een uitsplitsing naar het beroep/sector-, het opleiding- en het interactieeffect voor de periode 1979-1985, 1985-1989 en 1989-1994. Daarbij zijn de absolute waarden van de verschuivingen telkens gesommeerd.

Tabel 4.2. Relatieve belang van het beroep/sectorstructuur-, het opleidingstructuur en het interactieeffect

\begin{tabular}{ccccc}
\hline Periode & $\begin{array}{c}\text { saldo } \\
\text { totaal-effect }\end{array}$ & $\begin{array}{c}\text { beroep/sector- } \\
\text { effect }\end{array}$ & opleidingseffect & interactie-effect \\
\hline $1979-1985$ & 25,2 & 10,1 & 19,5 & 4,0 \\
$1985-1989$ & 12,6 & 3,2 & 11,8 & 1,3 \\
$1989-1994$ & 8,6 & 1,7 & 7,9 & 0,2 \\
\hline
\end{tabular}

Uit de tabel blijkt dat naar verwachting de totale dynamiek in de opleidingstructuur van de werkgelegenheid aanmerkelijk afneemt. Dat geldt ook voor de drie onderscheiden effecten afzonderlijk. Zoals in paragraaf 4.3. reeds werd aangegeven hangt deze daling deels ook samen met de prognosemethodiek. Het opleidingseffect blijkt over alle drie perioden de belangrijkste oorzaak van de verschuivingen in de opleidingenstructuur van de werkgelegenheid. Het beroep/sectoreffect lijkt een minder sterke invloed te hebben op de opleidingstructuur van de werkgelegenheid. Het interactie-effect is in alle gevallen zeer klein.

Het sterke opleidingsstruktuureffect kan niet zonder meer als een verdringingseffect worden geïnterpreteerd. Binnen een beroepsklasse kan immers een verschuiving hebben plaatsgevonden naar andere functieniveau's. Dit wordt in de shift/share analyse door de gebruikte beroepenindeling niet volledig zichtbaar gemaakt. Het gecombineerde beroep/sectoreffect duidt er op dat de verschuiving in de opleidingsstructuur in ieder geval voor een deel door de vraagzijde gestuurd is. 
Figuur 4.6. Het beroep/sectorstructuur-, het opleidingsstructuur- en het interactie-effect naar opleidingstype voor de periode 1989-1994 (gemeten in \%-punt verschuivingen)

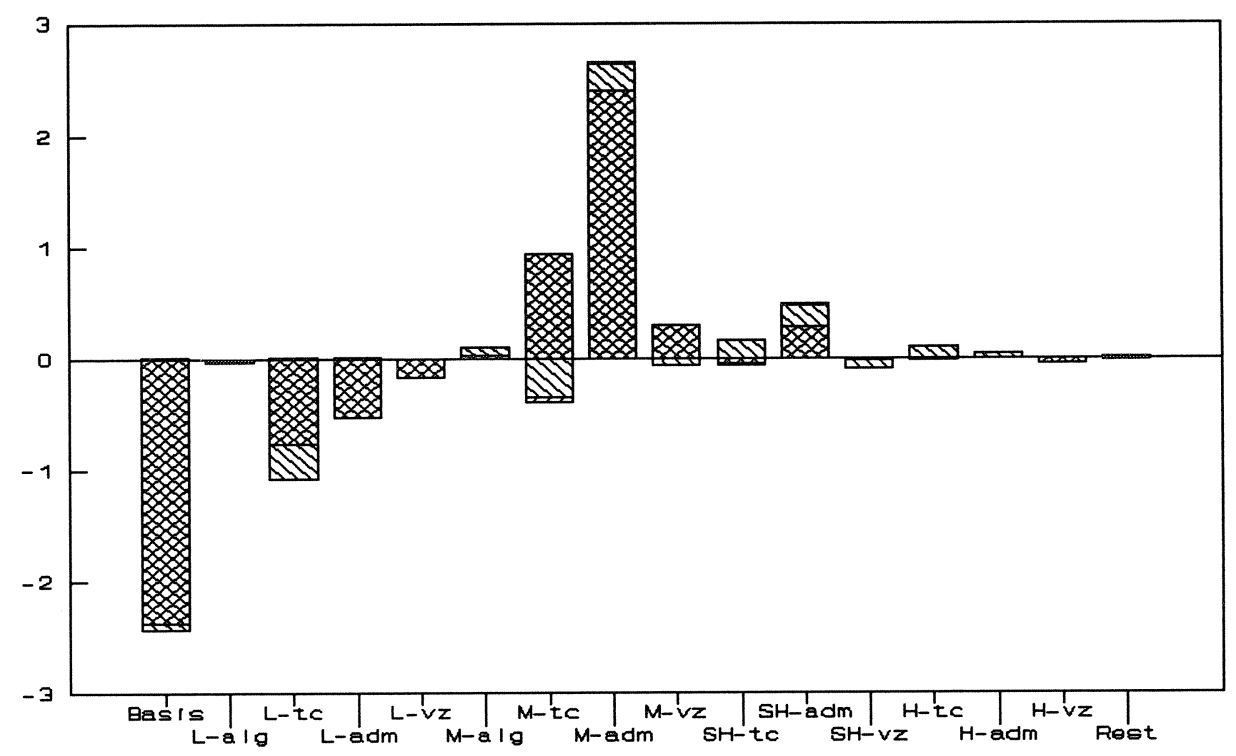

opleldingseffect

Figuur 4.6. laat zien welke verschuivingen ten grondslag liggen aan de voorspelde werkgelegenheidsontwikkeling van de verschillende opleidingscategorieën. Daarbij is uitgegaan van een meer globale opleidingsindeling zoals ook door het CPB (Kuhry en Van Opstal, 1987) wordt gebruikt: vijf opleidingsniveau's (basisonderwijs, LBO, MBO, HBO en WO) en vier opleidingsrichtingen (algemeen, technisch, administratief en verzorgend). De opleidingen die hier niet binnen vallen zijn ondergebracht in een rest-categorie.

Uit de figuur blijkt dat naar verwachting de grootste werkgelegenheidsdaling zich voordoet bij de opleidingen op het laagste niveau. Daarentegen doet de grootste werkgelegenheidsgroei zich naar verwachting voor bij de MBO en HBO opleidingen. Gemeten in procentpunten is de verwachte groei van de werkgelegenheid voor het universitair onderwijs naar verwachting slechts gering.

Wanneer we kijken naar de verschillende componenten van de werkgelegenheidsontwikkeling, blijkt overduidelijk het grote belang van het opleidingseffect. Voor degenen zonder een voltooide voortgezette opleiding (alleen basisonderwijs) is het opleidingseffect vrijwel geheel verantwoordelijk voor de verwachte werkgelegenheidsdaling. Ook bij de LBO- opleidingen op 
$-41-$

technisch en op economisch-administratief gebied is er een sterk negatief opleidingseffect. Bij de middelbare opleidingen op economisch-administratief gebied zien we het sterkste positieve opleidingeffect, gevolgd door middelbare opleidingen op technisch gebied en verzorgend gebied. Ook bij de HBO-opleidingen op economisch-administratief gebied doet zich naar verwachting een positief opleidingseffect voor.

De technische opleidingen op lager en middelbaar niveau zijn de opleidingstypen met de grootste negatieve beroep/sectoreffecten. Bij het middelbaar niveau weegt dit negatieve effect echter niet op tegen het genoemde positieve opleidingsstructuureffect, waardoor per saldo sprake is van een toename van het werkgelegenheidsaandeel. De economisch-administratieve opleidingen op middelbaar en HBO-niveau zijn de opleidingstypen met het grootste verwachte positieve beroep/sectoreffect, gevolgd door het technisch onderwijs op HBO- en universitair niveau. Het spiegelbeeld dat deze hogere technische opleidingen hier laten zien ten opzichte van de technische opleidingen op lager en middelbaar niveau duidt op het verschuiven van de beroepenstructuur in de richting van hoger geschoolde technische beroepen.

Samenvattend kunnen een aantal conclusies worden getrokken over de verschuivingen in de werkgelegenheids- en opleidingsstructuur. Ten eerste is er meer dynamiek op de arbeidsmarkt dan men uit een globale analyse kan aflezen, omdat verschillende typen effecten elkaar deels kunnen compenseren. Ten tweede blijkt, met uitzondering van de prognoseperiode, het sectoreffect ongeveer even sterk als het beroepseffect. Het beroepseffect is vooral aantoonbaar bij de groeiberoepen. Ten derde blijkt de verandering in de opleidingsstructuur voor het grootste deel veroorzaakt te worden door veranderingen in de opleidingsaandelen binnen een beroepsklasse. Desalniettemin is ook duidelijk sprake van vraagzijde gestuurde factoren. 
$\ldots$ 


\section{SEXE, ONDERWIJS EN ARBEIDSMARKT}

\subsection{Inleiding}

In dit hoofdstuk staat de relatie tussen sexe en de aansluitingsproblematiek op de arbeidsmarkt centraal ${ }^{17}$. Hierbij is het primaire doel om een beschrijving te geven van de verschillen tussen mannen en vrouwen in hun positie op de arbeidsmarkt. Enerzijds worden een aantal sexespecifieke arbeidsmarktontwikkelingen uit het recente verleden besproken. Anderzijds worden prognoses over ondermeer de arbeidsmarktperspectieven van enkele typische vrouwenberoepen en vrouwenopleidingen gepresenteerd.

Dit hoofdstuk is als volgt ingedeeld. In paragraaf 5.2. worden de verschillen tussen mannen en vrouwen in arbeids(markt)-participatie aangegeven. In dit kader wordt naast de participatiegraad aandacht besteed aan deeltijdarbeid en werkloosheid. Vervolgens wordt in paragraaf 5.3. de segregatie c.q. scheiding tussen werkzame mannen en vrouwen voor wat betreft hun onderwijskwalificatie en huidige beroep uiteengezet. Daarna wordt in paragraaf 5.4 . de huidige en toekomstige arbeidsmarktpositie gekarakteriseerd van beroepsbeoefenaren die in typische vrouwenberoepen werkzaam zijn. Paragraaf 5.5. eindigt met een beschrijving van enkele arbeidsmarktkarakteristieken van traditionele vrouwenopleidingen.

\subsection{Participatiegraad, deeltijdarbeid en werkloosheid.}

Sinds de jaren zestig is het percentage vrouwen dat zich meldt op de arbeidsmarkt sterk gestegen (zie ook Rapportage Arbeidsmarkt, 1990). Deze participatie op de arbeidsmarkt wordt meestal uitgedrukt in de zogenaamde 'participatiegraad' of het 'deelnemingspercentage'. Mannen en vrouwen zijn wat betreft hun participatie op de arbeidsmarkt in de afgelopen decennia in belangrijke mate naar elkaar toegegroeid. In 1960 bedroeg de participatiegraad ${ }^{18}$ voor mannen 90 en voor vrouwen 26 procent, terwijl in 1987 deze percentages respectievelijk 76 en 44 bedroegen (Rapportage Arbeidsmarkt, 1990).

Bij de mannen is de participatiegraad gedaald door enerzijds een hogere onderwijsparticipatie van jongere mannen en anderzijds een toename van het aantal (oudere) mannen dat arbeidsongeschikt is of vervroegd uittreedt. De participatie van mannen tussen de 25 en 50 jaar

17. Zie voor een uitvoerige beschrijving van de relatie tussen sexe, onderwijs en arbeidsmarkt, Van de Loo en Van der Velden (1991).

18. Het gaat hier om het aandeel van de beroepsbevolking in de bevolking van 15 tot 65 jaar. 
is nagenoeg niet veranderd. Bij vrouwen daarentegen heeft de stijgende participatie zich, ondanks de langere duur van de initiële opleiding van jongeren, vooral in de middelste leeftijdsklassen van met name gehuwde vrouwen voltrokken. Met andere woorden: in de 'vruchtbare' levensfase van (gehuwde) vrouwen (Bruyn-Hundt, 1988).

Tabel 5.1. Participatiegraad ${ }^{19}$ naar sexe en opleidingsniveau in 1979 en 1985

\begin{tabular}{lcccc}
\hline & \multicolumn{2}{c}{ Mannen } & \multicolumn{2}{c}{ Vrouwen } \\
Opleidingsniveau & 1979 & 1985 & 1979 & 1985 \\
& & & & \\
\hline & & & 22,8 & 27,1 \\
Basisonderwijs & 81,8 & 76,0 & 46,3 & 45,7 \\
MAVO & 94,3 & 89,2 & 36,5 & 42,7 \\
LBO & 92,9 & 90,6 & 58,8 & 65,6 \\
HAVO/VWO & 96,4 & 93,9 & 54,3 & 59,2 \\
MBO & 95,6 & 93,0 & 64,9 & 73,0 \\
HBO & 97,0 & 94,3 & 78,8 & 85,9 \\
WO & 98,6 & 96,5 & & \\
\hline
\end{tabular}

Bron: $\mathrm{CBS} / \mathrm{ROA}$

Er bestaat een positieve samenhang tussen de participatiegraad en het opleidingsniveau (zie tabel 5.1.). Vooral voor vrouwen geldt dat een hoog opleidingsniveau gepaard gaat met een relatief hoge participatie. Overigens kan men in deze tabel ook de dalende participatie bij mannen en de stijgende participatie van vrouwen constateren. Met uitzondering van vrouwen met MAVO als hoogst genoten onderwijs, is dit een trend die zich op alle onderwijsniveaus manifesteert. De dalende participatie bij mannen heeft zich relatief meer voorgedaan bij mannen met een laag onderwijsprofiel, terwijl de toegenomen participatie onder vrouwen daarentegen in verhouding meer onder middelbaar en hoger opgeleide vrouwen heeft plaatsgevonden.

Het CPB (Kuhry en Van Opstal, 1987) heeft bij het opstellen van prognoses over het arbeidsaanbod eveneens toekomstige participatiegraden voor zowel mannen als vrouwen berekend. De stijgende participatie onder vrouwen in het verleden wordt door hen in het jaar 2000 tot $58 \%$ doorgetrokken, terwijl de participatiegraad van mannen op het niveau van 1985 , namelijk $89 \%$, wordt bevroren.

Hoewel de participatiegraad meestal als centrale indicator wordt gebruikt voor ontwikkelingen in

19. De participatiegraad betreft hier de beroepsbevolking als percentage van de potentiële beroepsbevolking (personen van 15 tot 65 jaar voor zover geen scholier of student). 
$-44-$

het arbeidsaanbod van vrouwen, geeft dit slechts een beperkt inzicht in de dynamiek van het arbeidsaanbod. Het 'werkgelegenheidsaandeel' is hiervoor eigenlijk inzichtelijker ${ }^{20}$. Doordat vrouwen vaker dan mannen in deeltijd werken en de geregistreerde werkloosheid onder vrouwen hoger is dan die onder mannen, is het werkgelegenheidsaandeel voor vrouwen, kleiner dan de participatiegraad. Zo was het aandeel van vrouwen in de beroepsbevolking in 1983 $34 \%$, maar het werkgelegenheidsaandeel slechts 26\% (Bruyn-Hundt, 1988). Bovendien is, ondanks de forse stijging van de participatiegraad onder (gehuwde) vrouwen sinds het begin van de jaren zestig, het werkgelegenheidsaandeel van vrouwen in deze periode beduidend minder sterk gestegen dan de participatiegraad. In de periode 1977-1985 is het werkgelegenheidsvolume van vrouwen met $16 \%$ gestegen, terwijl het aantal werkzame vrouwen in dezelfde periode is toegenomen met ruim $29 \%$ (Huijgen, 1989).

Dit beeld wordt bevestigd wanneer de wekelijkse arbeidsduur van de in loondienst werkende vrouwen in 1979 wordt vergeleken met die in 1985. In 1979 werkte 56\% van deze vrouwen in een full-time baan, terwijl in 1985 nog maar $46 \%$ een volledige arbeidsweek had. Daarentegen is het percentage in deeltijd werkende vrouwen in deze periode fors toegenomen.

Figuur 5.1. Wekelijkse arbeidsduur (in uren) van vrouwen en mannen in loondienst in 1989

Vrouwen

vrouwen in loondienst naar arbeidsduur

in 1809 in proconton (EEO)

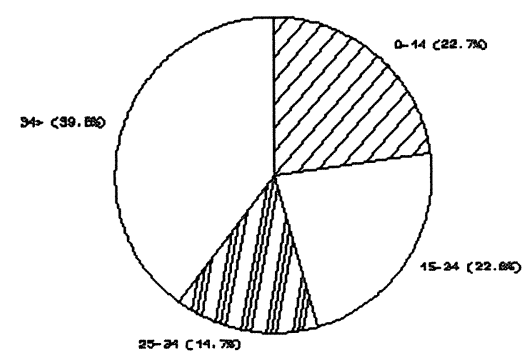

Mannen

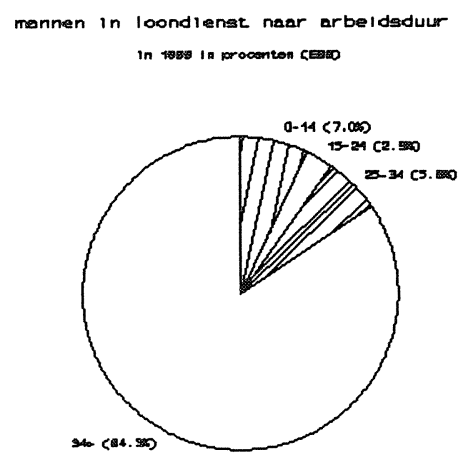

Bron: $\mathrm{CBS} / \mathrm{ROA}$

20. Het gaat hier om het aandeel van de werkzame bevoking in de potentiële beroepsbevolking van 15 tot 65 jaar. De werkzame bevolking wordt daarbij uitgedrukt in arbeidsjaren. 
Dat deeltijdwerk vrouwenwerk is, blijkt ook uit figuur 5.1. Daarin is voor zowel mannen als vrouwen aangegeven hoeveel uur zij wekelijks werkzaam zijn. Van de mannen heeft bijna $85 \%$ een full-time baan, terwijl daarentegen van de vrouwen nog geen $40 \%$ een volledige arbeidsbetrekking heeft. Mannen blijken, voor zover zij in deeltijd werken, met name zeer kleine deeltijdbanen te hebben. Bij de mannen gaat het hier met name om scholieren en studenten die naast hun studie een bijbaantje hebben.

De verschillen tussen beide sexen met betrekking tot het werkgelegenheidsaandeel in vergelijking met de participatiegraad worden niet alleen bepaald door de verschillen in deeltijdwerk, maar evenzeer door verschillen in het verwerven, dan wel het verliezen van betaald werk. Zo blijkt de werkloosheid voor vrouwen verhoudingsgewijs hoger te zijn dan voor mannen. Ook blijken vrouwen minder geprofiteerd te hebben van de daling van de werkloosheid. Terwijl tussen 1988 en 1990 het aantal werkloze mannen met bijna een kwart is gedaald, nam de werkloosheid onder vrouwen in die periode slechts met $13 \%$ af. Dit sexeverschil heeft met name betrekking op de kortdurende werkloosheid van minder dan een jaar. Tussen 1988 en 1990 is de kortdurende werkloosheid onder mannen driemaal zo snel gedaald als die onder vrouwen, terwijl de langdurige werkloosheid bij mannen en vrouwen ongeveer even snel afneemt (Rapportage Arbeidsmarkt, 1990).

\subsection{Onderwijs- en beroepssegregatie}

In de regel wordt bij (geslachtsspecifieke) segregatie alleen de (horizontale) beroepssegregatie in beschouwing genomen. Hierdoor blijft een belangrijke component van de segregatie buiten beschouwing. Er bestaat immers een sterke relatie tussen opleiding en beroep, zodat de totale beroepssegregatie kan worden gesplitst in twee componenten. Allereerst vindt er tijdens het onderwijstraject een voorsortering naar opleidingskwalificatie plaats. Daarna volgt een tweede sortering tijdens het arbeidsleven met betrekking tot de beroepskeuze en de loopbaantrajecten (Groot, 1990).

In deze paragraaf zullen daarom zowel de opleidings- ${ }^{21}$, als beroepssegregatie aan bod komen. Voor beide vormen van segregatie zullen twee segregatie-indices worden gebruikt. Beide indices kunnen een waarde aannemen tussen 0 en 100. De index (s) geeft antwoord op de vraag hoe groot de som is van het percentage van de mannelijke beroepsbevolking en het percentage van

21. Het gaat hierbij om de opleidingssegregatie op basis van de actieve beroepsbevolking, omdat op deze wijze de relatie tussen opleidings- en beroepssegregatie kan worden geanalyseerd. Vanaf volgend jaar zal echter ook de opleidingssegregatie op basis van de uitstroom uit het voltijdsonderwijs worden berekend. 
de vrouwelijke beroepsbevolking dat van beroep, c.q. opleiding dient te veranderen ten einde alle segregatie te doen verdwijnen. De gecorrigeerde index (s) geeft aan welk percentage van de totale beroepsbevolking van beroep of opleiding moet veranderen, onder de restrictie dat de verdeling van de totale beroepsbevolking over de onderscheiden beroepen, c.q. opleidingen ongewijzigd blijft (zie ook Siegers, 1979 en Groot, 1990).

Ontwikkelingen in de opleidings- en beroepssegregatie tussen mannen en vrouwen kunnen worden ontleed in een drietal componenten (Van Mourik en Siegers, 1988):

* veranderingen ten gevolge van wijzigingen in het aandeel van vrouwen in de actieve beroepsbevolking;

* veranderingen ten gevolge van wijzigingen in de verdeling van de totale actieve beroepsbevolking over opleidingsachtergronden en beroepen;

* veranderingen ten gevolge van wijzigingen in de aantalsverhouding tussen mannen en vrouwen binnen bepaalde opleidingsachtergronden en beroepen.

De ontwikkelingen in index $\mathrm{S}$ zijn het gevolg van ontwikkelingen in de eerstgenoemde component en in index $\mathbf{s}$. Wijzigingen in index $\mathbf{s}$ zijn het resultaat van veranderingen in de twee laatstgenoemde componenten in de segregatie.

De onderwijssegregatie tussen mannen en vrouwen heeft met name betrekking op de richting van het door hen gevolgde onderwijs. Dit blijkt uit de onderwijssegregatie-indices $s$ en $\mathrm{S}$ in tabel 5.2., waarbij de opleidingen respectievelijk naar niveau ${ }^{22}$ en richting ${ }^{23}$ zijn onderscheiden. Vrouwen blijken oververtegenwoordigd te zijn in de verzorgende, economisch \& administratieve, pedagogische en algemene opleidingen. Daarentegen zijn mannen oververtegenwoordigd bij de technische en agrarische opleidingen. In 1985 zou 19\% van de actieve beroepsbevolking bij een gelijkblijvende opleidingsstructuur van opleidingsrichting hebben moeten veranderen om de onderwijssegregatie ongedaan te maken, terwijl dit percentage met betrekking tot de segregatie naar opleidingsniveau slechts $2 \%$ bedraagt. De sterke segregatie naar richting duidt derhalve op een tamelijk sterke voorsortering naar opleidingsrichting (Groot, 1990).

22. Het gaat hier om de vier met de Standaard Onderwijs Indeling (SOI) van het CBS corresponderende niveaus: basisonderwijs, lager (beroeps)onderwijs, middelbaar (beroeps)onderwijs en hoger onderwijs.

23. Het gaat hier om de vijf richtingen: algemeen, pedagogisch, technisch en agrarisch, medisch en verzorgend, evenals economisch en juridisch. 
Tabel 5.2. Onderwijssegregatie-indices in 1985 in procenten

s

Bron: Groot, 1990

Juist omdat de onderwijssegregatie naar niveau veel geringer is dan de segregatie naar richting, is nagegaan hoe deze segregatie naar richting zich heeft ontwikkeld tussen 1979 en 1985 . De betreffende segregatie-indices zijn bepaald per opleidingsniveau. Uit tabel 5.3. valt af te lezen, dat de segregatie tussen mannen en vrouwen naar opleidingsrichting met het toenemen van het opleidingsniveau afneemt. Voor werkenden met een LBO-of MBO-kwalificatie is de scheiding tussen typische mannen- en vrouwenopleidingen derhalve groter dan voor degenen die een HBO- of WO-opleiding hebben genoten. De gecorrigeerde segregatie-index $S$ blijkt op alle opleidingsniveaus tussen de jaren 1979 en 1985 licht te zijn gestegen. Deze toegenomen scheiding tussen de opleidingskwalificaties van werkende mannen en vrouwen is met name het gevolg van het feit dat het aandeel van vrouwen in de totale actieve beroepsbevolking is gestegen van $29 \%$ in 1979 naar $34 \%$ in 1985 . Immers, de kleine s is, uitgezonderd het laagste niveau, op alle niveaus (licht) gedaald (zie ook Van Mourik en Siegers, 1988). Uit het verschil tussen deze twee blijkt het belang om beide indices te presenteren.

Tabel 5.3. Onderwijssegregatie per opleidingsniveau in 1979 en 1985

\begin{tabular}{|c|c|c|c|c|}
\hline \multirow[b]{2}{*}{ Opleidingsniveau } & \multicolumn{2}{|c|}{1979} & \multicolumn{2}{|c|}{1985} \\
\hline & $s$ & $\mathrm{~S}$ & $\mathbf{s}$ & $\mathrm{S}$ \\
\hline LBO, MAVO, Onderbouw HAVO/VWO & 59 & 26 & 63 & 29 \\
\hline MBO, Bovenbouw HAVO/VWO & 55 & 22 & 52 & 23 \\
\hline HBO & 38 & 16 & 37 & 18 \\
\hline Wo & 33 & 8 & 32 & 10 \\
\hline
\end{tabular}

Voor het vaststellen van de beroepssegregatie zijn de segregatie-indices $s$ en $S$ berekend op basis van gegevens over het aantal werkzame personen per beroepsgroep. Anders dan Van Mourik en Siegers (1988), die alleen de beroepssegregatie voor de gehele beroepsbevolking 
hebben gemeten, is hier per functieniveau ${ }^{24}$ nagegaan hoe de geslachtsspecifieke beroepssegregatie zich in de periode 1979-1985 heeft ontwikkeld (tabel 5.4.).

De beroepssegregatie lijkt zich sterker voor te doen in het middenkader, dan in de beroepsgroepen met een lager, dan wel een hoger beroepsniveau. Hierbij moet wel rekening worden gehouden met het feit, dat het aantal beroepsgroepen de hoogte van de indices positief beïnvloed. Aan de verschillen tussen de onderscheiden functieniveaus voor wat betreft de hoogte van de segregatie-indices kunnen derhalve geen (harde) conclusies worden verbonden.

Tabel 5.4. Beroepssegregatie per functieniveau in 1979 en 1985

\begin{tabular}{|c|c|c|c|c|c|}
\hline \multirow[t]{2}{*}{ functieniveau } & \multirow[t]{2}{*}{ aantal beroepsgroepen } & \multicolumn{2}{|c|}{1979} & \multicolumn{2}{|c|}{1985} \\
\hline & & $s$ & $\mathrm{~S}$ & $s$ & $\mathrm{~S}$ \\
\hline 1 & 31 & 49 & 19 & 61 & 28 \\
\hline 2 & 74 & 70 & 28 & 66 & 30 \\
\hline 3 & 42 & 66 & 31 & 62 & 31 \\
\hline 4 & 49 & 70 & 29 & 69 & 32 \\
\hline 5 & 58 & 70 & 26 & 64 & 26 \\
\hline 6 & 36 & 59 & 16 & 54 & 15 \\
\hline 7 & 24 & 35 & 12 & 30 & 12 \\
\hline Totaal & 314 & 66 & 27 & 64 & 28 \\
\hline
\end{tabular}

Het is daarom beter de verschillen tussen de functieniveaus met betrekking tot de ontwikkeling van de segregatie tussen 1979 en 1985 te analyseren. Met uitzondering van het laagste functieniveau blijkt in de beschouwde periode de segregatie-index $s$ op alle functieniveaus te zijn gedaald, terwijl tussen 1979 en 1985 de index S vrij constant is gebleven. Voor het laagste functieniveau daarentegen geldt dat beide indices tussen 1979 en 1985 sterk zijn gestegen. Dit is waarschijnlijk enerzijds het gevolg van het feit, dat de toename van vrouwen juist in beroepen op het laagste functieniveau heeft plaatsgevonden. Anderzijds zijn mannen met name uit beroepen op het laagste functieniveau vertrokken. Het laagste functieniveau lijkt dus meer en meer een 'vrouwensegment' te worden (zie ook Elfring en Kloosterman, 1989).

Aan het eind van deze paragraaf is het interessant om te bezien in hoeverre de onderwijs- en beroepssegregatie aan elkaar zijn gerelateerd. Daarbij gaat het met name om de vraag hoe groot

24. De bepaling van het functieniveau is ontleend aan Huijgen (1989). 
$-49-$

de beroepssegregatie is voor mensen met eenzelfde opleidingsachtergrond. Deze beroepssegregatie, de zogenaamde 'nasortering', is volgens Groot (1990) $14 \%$. Deze $14 \%$ van de nasortering komt in principe bovenop de $20 \%$ van de voorsortering binnen het onderwijs. Hierbij dienen wel twee kanttekeningen te worden gemaakt. Ten eerste tellen de voorsortering van $20 \%$ en de nasortering van $14 \%$ niet op tot de totale beroepssegregatie van $25 \%-30 \%$ omdat beide componenten van de totale beroepssegregatie elkaar voor een deel kunnen compenseren. Ten tweede kunnen er ook binnen de onderscheiden opleidingsrichtingen verschillende specifieke opleidingen bestaan, waarin ofwel mannen, ofwel vrouwen sterk zijn oververtegenwoordigd; opleidingen die bovendien niet op dezelfde beroepssegmenten zijn gericht (bijvoorbeeld MEAO-commercieel versus MEAO-secretarieel). Dit laatste kan betekenen dat het aandeel van de voorsortering in werkelijkheid nog groter is dan hier is aangegeven.

De conclusie ten aanzien van de opleidings- en beroepssegregatie tussen mannen en vrouwen is dat een belangrijk deel van de totale beroepssegregatie haar oorsprong vindt in een vrij sterke voorsortering binnen het onderwijstraject, maar dat in het daaropvolgende loopbaantraject de beroepssegregatie verder wordt versterkt. Bovendien blijken beide vormen van segregatie slechts geleidelijk te veranderen.

\subsection{Arbeidsmarktkarakteristieken van vrouwenberoepen}

In deze paragraaf zullen enkele kenmerken van typisch 'vrouwelijke' beroepsklassen worden besproken. Het gaat hier om de beroepsklassen ${ }^{25}$, waarin $60 \%$ of meer van de beroepsbeoefenaren in 1985 uit vrouwen bestaat. De betreffende kenmerken staan vermeld in tabel 5.5.

Het percentage vrouwen in de onderscheiden vrouwenberoepen is in 1985 gemiddeld $76 \%$ en varieert van $60 \%$ voor de 'koks, kelners en serveersters' tot $96 \%$ voor het 'verzorgend en huishoudelijk personeel'. In de totale actieve beroepsbevolking bedraagt het percentage vrouwen $34 \%$, zodat men kan concluderen, dat in deze vrouwenberoepen ruim twee maal zoveel vrouwen zijn vertegenwoordigd, dan gemiddeld in een beroepsklasse.

25. Vanaf komend jaar wil het ROA haar beroepeninformatie gaan baseren op een nieuwe beroepsklassenindeling, die het resultaat is van een hergroepering van de beroepsgroepen van het CBS. De opleidingsachtergrond heeft bij deze clustering als leidraad gediend. Juist omdat sexe en opleidingsrichting aan elkaar gerelateerd blijken te zijn, zijn de nieuwe ROA-beroepsklassen ook wat betreft de sexeverhoudingen homogener samengesteld. Zie Dekker, De Grip en Van de Loo (1990). 
$-50-$

Tabel 5.5. Arbeidsmarktkarakteristieken van vrouwenberoepen

\begin{tabular}{|c|c|c|c|c|c|c|c|c|c|c|c|}
\hline CBS-code & beroepsklasse & $a$ & b & c & $d$ & $\mathrm{e}$ & $f$ & g & $\mathrm{h}$ & $\mathrm{i}$ & j \\
\hline 06/07 & $\begin{array}{l}\text { Genees- en ver- } \\
\text { pleegkundigen }\end{array}$ & 72 & 11 & + & + & $=$ & $=$ & $=$ & $=$ & - & $=$ \\
\hline 32 & $\begin{array}{l}\text { Secretaressen, typis- } \\
\text { ten }\end{array}$ & 95 & 8 & $=$ & $=$ & $=$ & + & -- & $=$ & + & + \\
\hline 38 & $\begin{array}{l}\text { Telefonisten, telegra- } \\
\text { fisten }\end{array}$ & 82 & 1 & $=$ & - & $=$ & + & -- & -- & + & $=$ \\
\hline 48 & $\begin{array}{l}\text { Winkelbedienden } \\
\text { e.a. verkopers }\end{array}$ & 71 & 10 & - & -- & $=$ & ++ & -- & + & ++ & ++ \\
\hline 53 & $\begin{array}{l}\text { Koks, kelners, } \\
\text { serveersters e.d. }\end{array}$ & 60 & 4 & - & -- & $=$ & + & -- & $=$ & $=$ & $=$ \\
\hline 54 & $\begin{array}{l}\text { Verzorgend en huis- } \\
\text { houdelijk personeel }\end{array}$ & 96 & 10 & - & -- & $=$ & ++ & -- & $=$ & $=$ & $=$ \\
\hline 55 & $\begin{array}{l}\text { Schoonmakers, con- } \\
\text { ciërges }\end{array}$ & 74 & 6 & -- & -- & - & ++ & -- & $=$ & $=$ & $=$ \\
\hline 56 & Wasserijpersoneel & 72 & 0 & -- & -- & $=$ & $=$ & $=$ & $=$ & ++ & + \\
\hline 57 & $\begin{array}{l}\text { Kappers, } \\
\text { schoonheid- } \\
\text { specialisten }\end{array}$ & 77 & 1 & $=$ & $=$ & - & + & + & $=$ & $=$ & $=$ \\
\hline 59 & $\begin{array}{l}\text { Overige dienstverle- } \\
\text { nende functies }\end{array}$ & 68 & 1 & $=$ & $=$ & $=$ & + & - & $=$ & + & + \\
\hline 79 & $\begin{array}{l}\text { Confectiemakers, } \\
\text { stoffeerders }\end{array}$ & 66 & 1 & - & - & ++ & ++ & $=$ & $=$ & - & - \\
\hline Gemiddelde & vrouwenberoepen & 76 & & - & - & $=$ & + & - & $=$ & $=$ & $=$ \\
\hline Gemiddelde & CBS-beroepsklassen & 34 & & 3,7 & 0,01 & 1,75 & 17 & 9 & 6 & 12 & 18 \\
\hline
\end{tabular}

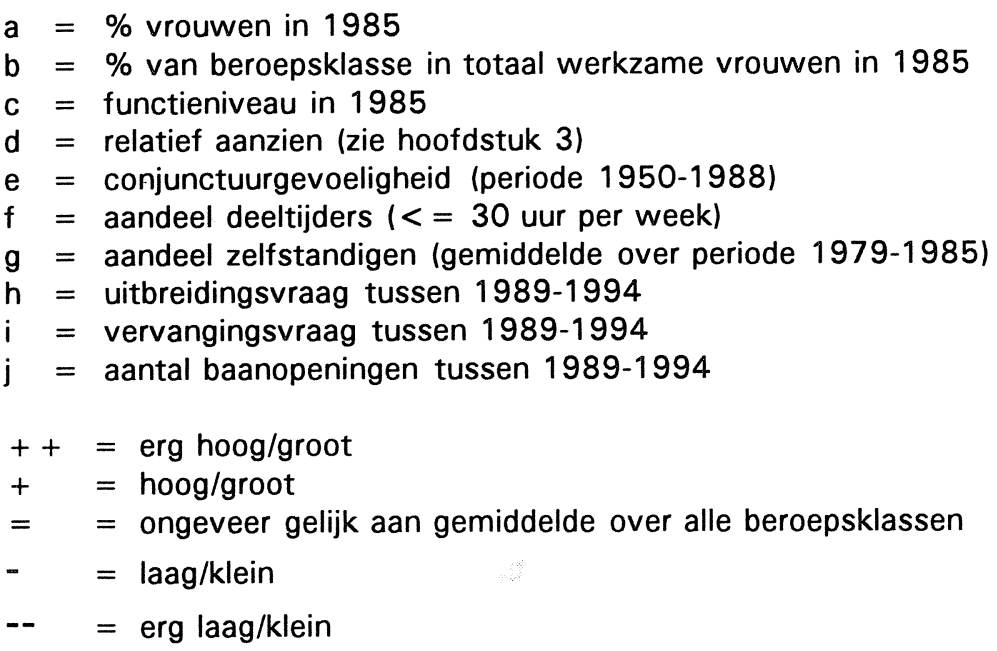


Van de werkende vrouwen blijkt in $198553 \%$ in één van deze elf vrouwenberoepen werkzaam; $49 \%$ van de werkgelegenheid voor vrouwen doet zich zelfs voor in slechts zes van deze beroepsklassen: genees- en verpleegkundigen, winkelbedienden e.a. verkooppersoneel, verzorgend en huishoudelijk personeel, secretaressen en typisten, schoonmakers en conciërges, alsmede koks, kelners en serveersters.

Het functieniveau van deze beroepsklassen blijkt lager te zijn dan gemiddeld. Slechts én van de elf onderscheiden vrouwenberoepen heeft een relatief hoog functieniveau.

Naast het functieniveau is eveneens gekeken naar het 'relatieve aanzien' van de vrouwenberoepen op basis van een score voor het maatschappelijk aanzien van een beroepsklasse, waarbij wordt gecorrigeerd voor het functieniveau (zie ook hoofdstuk 3). Alleen de beroepsklasse van genees- en verpleegkundig personeel heeft een hoog relatief aanzien. Voor zeven van de elf beroepsklassen geldt echter dat het maatschappelijk aanzien van de beroepsklasse lager is dan men op grond van het functieniveau zou voorspellen. Het betreft hier met name de beroepsklassen met een lager functieniveau.

Conform de verwachtingen is het aandeel deeltijders ${ }^{26}$ in de vrouwenberoepen gemiddeld hoog. In vier van de elf beroepsklassen is zelfs een zeer hoog aandeel deeltijders te vinden. In geen enkel vrouwenberoep komt een laag percentage deeltijders voor.

In de vrouwenberoepen is het aandeel zelfstandigen gemiddeld laag te noemen. Alleen de beroepsklasse van kappers en schoonheidsspecialisten bevat relatief veel zelfstandige ondernemers. Binnen deze beroepsklasse werken vrouwen echter relatief vaker in loondienst dan mannen $(63 \%$ versus $40 \%)$.

Daarnaast is voor de vrouwenberoepen nagegaan of zij zijn over- of ondervertegenwoordigd in de branches die conjunctuurgevoelig zijn. Vrouwenberoepen blijken in doorsnee niet gevoeliger voor conjunctuurschommelingen dan alle beroepsklassen te samen. Afgezien van de zeer conjunctuurgevoelige beroepsklasse van confectiemakers en stoffeerders, blijken de vrouwenberoepen meestal een gemiddelde en soms zelfs een relatief lage conjunctuurgevoeligheid te hebben.

Tot nu toe zijn een aantal actuele kenmerken van de vrouwenberoepen besproken. Van groot belang zijn uiteraard ook de arbeidsmarktperspectieven voor de nabije toekomst voor de

26. Het gaat hierbij om het aandeel van de werkzame personen, dat in de periode 1979-1985 een werkweek van minder dan 30 uur had. 
werkenden in deze beroepsklassen. De som van de uitbreidingsvraag en de vervangingsvraag resulteert in de periode 1989-1994 bij de vrouwenberoepen in het algemeen in een gemiddeld tot relatief groot aantal baanopeningen. Daarbij speelt de vervangingsvraag meestal naar verhouding een belangrijkere rol dan bij de andere beroepen. In deze vaak (zeer) hoge vervangingsvraag weerspiegelt zich derhalve het participatiepatroon van vrouwen.

De uitbreidingsvraag is in de meeste gevallen gelijk aan de gemiddelde groei. De werkgelegenheidsgroei zal in de vrouwenberoepen de komende jaren dus niet beter of slechter zijn dan die in alle beroepsklassen te samen. Alleen de beroepsklasse van telefonisten behoort tot de krimpberoepen. Omgekeerd zal de vraag naar winkelpersoneel in de prognoseperiode naar verwachting juist relatief sterk gaan toenemen. De beroepsklasse van winkelbedienden e.a. verkooppersoneel behoort dan ook tot de groeiberoepen.

Tenslotte is in bijlage 10 een overzicht opgenomen, waarin voor alle vrouwenberoepen, gedifferentieerd naar sexe, de belangrijkste opleidingsachtergronden zijn aangegeven. Hieruit blijkt een groot verschil tussen beide sexen te bestaan voor wat betreft hun opleidingskwalificaties. Mannen blijken dus dikwijls vanuit geheel andere opleidingen door te stromen naar een 'vrouwenberoep' dan vrouwen.

\subsection{Arbeidsmarktkarakteristieken van vrouwenopleidingen}

Analoog aan de bespreking van de zogenaamde vrouwenberoepen zullen een aantal kenmerken van een achttal typisch 'vrouwelijke' opleidingstypen worden besproken ${ }^{27}$. De acht opleidingstypen met een percentage vrouwen van $60 \%$ of hoger in 1985 typeren we in deze paragraaf als de vrouwenopleidingen.

In tabel 5.6. zijn een aantal arbeidsmarktkenmerken weergegeven van de werkenden met een vrouwenopleiding. Deze worden steeds vergeleken met de gemiddelde scores voor het betreffende opleidingsniveau. Het percentage vrouwen in de geselecteerde opleidingen varieert van $60 \%$ voor LBO-ers met een economisch-administratieve kwalificatie tot $92 \%$ voor MBO-ers die een sociaal-verzorgende opleiding hebben genoten. Gemiddeld is in 1985 het percentage vrouwen voor deze opleidingstypen $78 \%$, terwijl de actieve beroepsbevolking voor slechts $34 \%$ uit vrouwen bestaat.

27. In 1985 had $37 \%$ van de werkende vrouwen een van deze opleidingen als opleidingsachtergrond. 
Tabel 5.6. Arbeidsmarktkarakteristieken van vrouwenopleidingen

\begin{tabular}{|c|c|c|c|c|c|c|c|c|c|c|c|}
\hline Opleidingstype & a & b & C & d & e & $f$ & $g$ & $h$ & $\mathrm{i}$ & j & k \\
\hline $\begin{array}{l}\text { LBO Economisch \& Admi- } \\
\text { nistratief }\end{array}$ & 60 & 5 & + & + & 3.0 & 36 & -- & + & $=$ & -- & matig \\
\hline $\begin{array}{l}\text { LBO Sociale Verzorging \& } \\
\text { Horeca }\end{array}$ & 89 & 13 & + & + & 2.4 & 67 & - & ++ & + & -- & goed \\
\hline Gemiddelde LBO & 30 & & $=$ & $=$ & 2.9 & 47 & - & + & $=$ & -- & redelijk \\
\hline MBO Pedagogiek & 65 & 1 & -- & $=$ & 4.1 & 37 & - & -- & - & - & redelijk \\
\hline MBO Verpleging & 85 & 5 & - & - & 4.6 & 15 & $=$ & + & + & - & redelijk \\
\hline $\begin{array}{l}\text { MBO Medisch Laboratori- } \\
\text { um }\end{array}$ & 72 & 1 & -- & $=$ & 4.2 & 12 & + & + & + & - & goed \\
\hline MBO Ziekenverzorging & 91 & 2 & - & -- & 3.7 & 22 & + & + & ++ & - & redelijk \\
\hline MBO Sociale Verzorging & 92 & 8 & - & + & 3.3 & 61 & + & ++ & ++ & $=$ & matig \\
\hline Gemiddelde MBO & 45 & & - & $=$ & 3.8 & 43 & ++ & $=$ & + & - & redelijk \\
\hline $\begin{array}{l}\text { HBO-Verpleging \& Fysio- } \\
\text { therapie e.d. }\end{array}$ & 67 & 2 & - & -- & 5.2 & 6 & $=$ & - & $=$ & + & slecht \\
\hline $\begin{array}{l}\text { HBO Medisch Laboratori- } \\
\text { um }\end{array}$ & 70 & 1 & -- & - & 4.8 & 17 & $=$ & $=$ & + & - & goed \\
\hline Gemiddelde HBO & 31 & 1 & - & $=$ & 5.9 & 23 & + & - & $=$ & - & matig \\
\hline
\end{tabular}

$a=\%$ vrouwen in 1985

b $=\%$ vrouwen met desbetreffende opleidingskwalificatie in totaal werkzame vrouwen in 1985

$\mathrm{c}=$ werkloosheidspercentage in april 1990

$\mathrm{d}=$ beroepenspreiding (gemiddelde 1979-1985)

$\mathrm{e}=$ gemiddeld functieniveau in 1985

$f=$ onderbenuttingsgraad in 1985

$\mathrm{g}=$ uitbreidingsvraag tussen 1989-1994

$\mathrm{h}=$ vervangingsvraag tussen 1989-1994

$\mathrm{i}=$ aantal baanopeningen tussen 1989-1994

$\mathrm{j}=$ instroom van schoolverlaters op de arbeidsmarkt tussen 1989-1994

$k=$ arbeidsmarktperspectief tussen 1989-1994

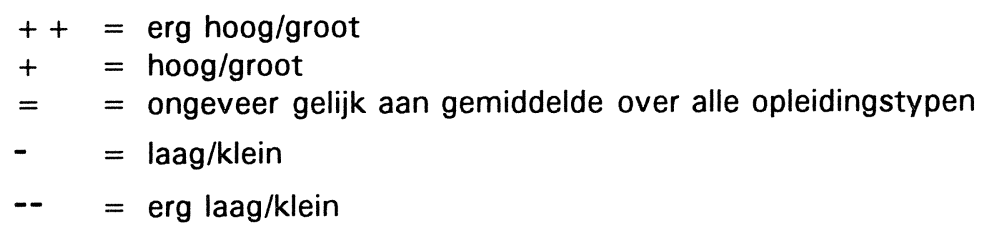

Op LBO-niveau blijken de beroepsbeoefenaren met een 'vrouwelijke' opleidingskwalificatie relatief vaker werkloos te zijn en een grotere beroepenspreiding te kennen dan gemiddeld. Binnen de groep 'vrouwelijk' opgeleide LBO-ers blijken de grootste verschillen momenteel het functieniveau en de onderbenutting te betreffen. Degenen met een sociaal-verzorgende oplei- 
ding hebben gemiddeld een lager functieniveau en werken vaker onder het niveau van hun opleiding, dan degenen die een economisch-administratieve opleiding hebben genoten. Doordat de werkgelegenheid voor LBO-ers met een economisch-administratieve opleiding in de nabije toekomst naar verwachting zeer sterk zal gaan inkrimpen, en dit niet door de hoge vervangingsvraag en de zeer lage instroom wordt gecompenseerd, wordt voor hen een matig perspectief verwacht. Bij de opleiding LBO Sociale Verzorging \& Horeca daarentegen zal de zeer hoge vervangingsvraag en zeer lage instroom de lage uitbreidingsvraag ruimschoots compenseren, zodat hier een goed arbeidsmarktperspectief verwacht wordt. Dit kan betekenen dat de verschillen in arbeidsmarktpositie tussen de LBO-ers met een sociaal-verzorgende en met een economisch-administratieve opleidingsachtergrond in de toekomst af zullen nemen.

Beroepsbeoefenaren met een 'vrouwelijke' MBO-kwalificatie blijken gemiddeld een hoger functieniveau te hebben en minder vaak onder het niveau van hun opleiding te werken dan gemiddeld voor het MBO geldt. Het redelijk tot goede arbeidsmarktperspectief voor schoolverlaters van vrouwenopleidingen op MBO-niveau is vooral te danken aan de hoge vervangingsvraag. De opleiding Sociale Verzorging blijkt niet geheel in het beeld van dit MBOonderwijs te passen. Werkenden met deze opleidingsachtergrond kennen een grotere beroepenspreiding, een lager functieniveau en werken in meerderheid onder het niveau van hun opleiding. Door een relatief hoge instroom van schoolverlaters op de arbeidsmarkt hebben zij, ondanks een zeer groot aantal baanopeningen, slechts een matig arbeidsmarktperspectief.

Op het HBO-niveau blijkt de beroepenspreiding voor degenen die met een 'vrouwelijke' opleidingsachtergrond werkzaam zijn beduidend kleiner dan gemiddeld. Hoewel het functieniveau bij de vrouwenopleidingen gemiddeld lager is dan bij het gehele $\mathrm{HBO}$, werkt men toch niet vaker onder het niveau van de opleiding. Voor HBO Verpleging \& Fysiotherapie wordt in de periode 1989-1994 een lage vervangingsvraag en een hoge instroom van schoolverlaters verwacht. Samen met een gemiddelde uitbreidingsvraag leidt dat tot een slecht arbeidsmarktperspectief. Het hogere medische laboratoriumonderwijs heeft daarentegen het goede arbeidsmarktperspectief in eerste instantie te danken aan de lage instroom van schoolverlaters.

Evenals bij de vrouwenberoepen is voor de werkenden met een 'vrouwelijke' opleidingsachtergrond, voor zowel de mannen als de vrouwen, nagegaan in welke beroepsklassen zij in 1985 werkzaam waren (zie bijlage 11). Uit dit overzicht blijkt, dat, ook als mannen en vrouwen eenzelfde opleidingsachtergrond hebben genoten, zij in verschillende beroepen terecht komen. Zoals reeds werd geconstateerd in paragraaf 5.3. over de opleidingsen beroepensegregatie kunnen de beroepsverschillen tussen mannen en vrouwen derhalve niet geheel worden toegeschreven aan de zogenaamde 'voorsortering' in het onderwijs. 


\section{LITERATUUR}

Beekman, Th.B.J., R.J.P. Dekker, A. de Grip, J.A.M. Heijke (1989), An explanation of the educational structure of occupations, ROA-W-1989/3E, Maastricht.

Bruyn-Hundt, M. (1988), Vrouwen op de arbeidsmarkt, Nederlandse situatie in de jaren tachtig en negentig, Scala-reeks, Het Spectrum, Utrecht.

Centraal Bureau voor de Statistiek (1989), Statistiek van het Ondernemingenbestand, Voorburg/Heerlen.

Commissie OAP (1989), Verslag van de werkgroep 'vergelijking en afstemming prognoses '89', Den Haag.

Dam, J.W. van, A. de Grip (1990), Technology indicators: Population, Labour and Schooling, ROA-R-1990/5E, Maastricht.

Dekker, R.J.P., A. de Grip, J.A.M. Heijke (1990), An explanation of the occupational structure of sectors of industry, in: Labour, vol. 4, nr. 3.

Dekker, R.J.P., A. de Grip, P.J.E. van de Loo (1990), ROA-Beroepenclassificatie 1990, ROA-W1990/9, Maastricht.

Elfring, T., R.C. Kloosterman (1989), De Nederlandse 'Jobmachine'; de snelle expansie van laagbetaald werk in de dienstensector 1979-1986, Paper Ecozoek, Economisch Geografisch Instituut (EGI), Amsterdam.

Grip, A. de (1987), Winnaars en verliezers op de arbeidsmarkt 1981-1985, in: Tijdschrift voor Arbeidsvraagstukken, jaargang 3, nr. 4, p. 61-69.

Grip, A. de, J.A.M. Heijke, R.J.P. Dekker (1989), De arbeidsmarkt naar opleiding en beroep in 1992, ROA-R-1989/8, Maastricht.

Groot, L.F.M. (1990), De onderwijs- en beroepssegregatie tussen mannen en vrouwen in de jaren tachtig, in: Tijdschrift voor Arbeidsvraagstukken (TvA), 1990/4, blz. 4-12.

Huijgen, F. (1989), De kwalitatieve structuur van de werkgelegenheid in Nederland, deel III, bevolking in loondienst en functiestructuur in 1977 en 1985, OSA-voorstudie nr. V 33, Organisatie voor Strategisch Arbeidsmarktonderzoek (OSA), Den Haag.

Hulst, N. van, L.L.G. Soete (1989), Export en technologische ontwikkeling in de industrie, in: Koninklijke Vereniging voor de Staathuishoudkunde, Export preadviezen van de Koninklijke Vereniging voor de Staathuishoudkunde 1989, blz. 63-85.

Kuhry, B., R.M. van Opstal (1987), De arbeidsmarkt naar opleidingscategorie 1975-2000, CPBW-1987/17, Centraal Planbureau (CPB), Den Haag.

Kleinknecht, A.H., J.O.N. Reijnen, J.J. Verweij (1990), Innovatie in de Nederlandse Industrie en Dienstverlening; een enquête-onderzoek, Ministerie van Economische Zaken, Beleidsstudies Technologie Economie nr. 6, 's-Gravenhage.

Loo, P.J.E. van de, R.K.W. van der Velden (1991), Sexe, onderwijs en arbeidsmarkt, Researchcentrum voor Onderwijs en Arbeidsmarkt (ROA), Maastricht (verschijnt binnenkort). 
Ministerie van Sociale Zaken en Werkgelegenheid (1990), Rapportage Arbeidsmarkt 1990, Ministerie van Sociale Zaken en Werkgelegenheid, Den Haag.

Mourik, A. van, J. Siegers (1988), Ontwikkelingen in de beroepssegregatie tussen mannen en vrouwen, 1971-1985, in: Economisch Statistische Berichten (ESB), 1988, blz. 732-737.

Peeters, H.M.M. (1990), An explanation of the occupational and educational structure of employment by means of multinomial logit, ROA-W-1990/4E, Maastricht.

Siegers, J. (1979), Beroepssegregatie tussen mannen en vrouwen in Nederland, in: Economisch Statistische Berichten (ESB), 1979, blz. 208-213.

Sixma, H., W.C. Ultee (1983), Een beroepsprestigeschaal voor de jaren tachtig, in: Mens en Maatschappij, 4, p. 360-382.

Teulings, C.N., H.D. Webbink (1990), Verschuivingen in werkgelegenheidsstructuren, in: Economische Statistische Berichten, vol. 75, nr. 3759, p. 469-472.

Wieling, M.H., A. de Grip en E.J.T.A. Willems (1990), Een systematische kwalitatieve typering van arbeidsmarktinformatie, ROA-W-1990/8, Maastricht.

Willems, E.J.T.A., A. de Grip (1990), Vervangingsvraagprognoses naar beroep en opleiding, ROA-W-1990/7, Maastricht. 
Bijlage 1: Uitbreidingsvraag 1989-1994 per beroepsklasse, absoluut en als percentage van het aantal werkzame personen in 1989

\begin{tabular}{|c|c|c|c|c|}
\hline CBS & beroepsklasse & aantal & $\%$ & typering \\
\hline 01 & Schei- , natuurkundigen e.d. & 250 & 1 & gemiddeld \\
\hline $02 / 03$ & Architecten, ingenieurs, tekenaars e.d. & 21200 & 11 & relatief hoog \\
\hline 04 & Vliegtuig- en scheepsofficieren & 1400 & 10 & relatief hoog \\
\hline 05 & Biologen, biochemici e.d. & 1300 & 4 & gemiddeld \\
\hline 06/07 & Genees- en verpleegkundig personeel & 20200 & 7 & gemiddeld \\
\hline 08 & Statistici, systeemanalisten e.d. & 45400 & 57 & relatief erg hoog \\
\hline 09 & Economen & 500 & 3 & gemiddeld \\
\hline 11 & Accountants & 650 & 5 & gemiddeld \\
\hline 12 & Juristen & 550 & 3 & gemiddeld \\
\hline 13 & Leerkrachten & 3900 & 1 & gemiddeld \\
\hline 14 & Bedienaars van eredienst e.d. & 400 & 5 & gemiddeld \\
\hline 15 & Auteurs, journalisten e.d. & 7400 & 26 & relatief erg hoog \\
\hline 16 & Beeldhouwers, kunstschilders e.d. & 1300 & 4 & gemiddeld \\
\hline 17 & Musici e.a. uitvoerende kunstenaars & 600 & 4 & gemiddeld \\
\hline 18 & Beroepssportlieden e.d. & 400 & 4 & gemiddeld \\
\hline 19 & Wetenschappelijk specialist n.e.g. & 3400 & 3 & gemiddeld \\
\hline 20 & Leidinggevenden bij openb. bestuur & 50 & 1 & gemiddeld \\
\hline 21 & Leidinggevenden excl. openb. best. & 42300 & 20 & relatief erg hoog \\
\hline 30 & Leidinggevend administratief pers. & 350 & 2 & gemiddeld \\
\hline 31 & Uitvoerende hoofdambtenaren & 250 & 1 & gemiddeld \\
\hline 32 & Secretaressen, typisten e.d. & 5100 & 3 & gemiddeld \\
\hline 33 & Boekhouders, kassiers e.d. & 12600 & 4 & gemiddeld \\
\hline 34 & Computerapparatuuroperateurs e.d. & 450 & 3 & gemiddeld \\
\hline 35 & Leidinggevend transportpersoneel & -100 & -0 & gemiddeld \\
\hline 36 & Conducteurs trein, tram, bus e.d. & -150 & -5 & relatief laag \\
\hline 37 & Post-distributiepersoneel & 22000 & 35 & relatief erg hoog \\
\hline 38 & Telefonisten, telegrafisten e.d. & -3300 & -23 & relatief erg laag \\
\hline 39 & Administratieve functies n.e.g. & 10700 & 3 & gemiddeld \\
\hline 40 & Directeur/bedr.leiders groothandel & 4600 & 12 & relatief hoog \\
\hline 41 & Directeur/bedr.leiders detailhandel & 2100 & 12 & relatief hoog \\
\hline 42 & Zelfst. groothandelaren & 3500 & 12 & relatief hoog \\
\hline 43 & Zelfst. winkeliers/detailhandelaren & 12300 & 12 & relatief hoog \\
\hline 45 & Leidinggevend commercieel personeel & -7100 & -18 & relatief erg laag \\
\hline 46 & Vertegenwoordigers, handelsagenten & 4100 & 7 & gemiddeld \\
\hline 47 & Verzekeringsagenten, makelaars e.d. & 1300 & 4 & gemiddeld \\
\hline 48 & Winkelbedienden e.a. verkopers & 29700 & 10 & relatief hoog \\
\hline 50 & Directeur/bedrijfsleider horeca & 550 & 5 & gemiddeld \\
\hline 51 & Zelfst. hotel-, rest.-, caféhouders & 1600 & 5 & gemiddeld \\
\hline 52 & Leidinggevend huishoudelijk pers. & 550 & 5 & gemiddeld \\
\hline 53 & Koks, kelners, buffetbediende e.d. & 5000 & 4 & gemiddeld \\
\hline 54 & Huishoudelijk en verz. pers. n.e.g. & 7900 & 5 & gemiddeld \\
\hline 55 & Huisbewaarders, schoonmaakpersoneel & 5200 & 4 & gemiddeld \\
\hline 56 & Wassers, persers e.d. & 500 & 5 & gemiddeld \\
\hline 57 & Kappers, schoonheidsspecialist e.d. & 1600 & 5 & gemiddeld \\
\hline 58 & Brandweer-, politiepersoneel e.d. & 850 & 1 & gemiddeld \\
\hline 59 & Dienstverlenende functies n.e.g. & 1800 & 6 & gemiddeld \\
\hline 60 & Bedrijfsleiders land- en tuinbouw & -150 & -2 & relatief laag \\
\hline 61 & Zelfstandige land- en tuinbouwers & -3500 & -3 & relatief laag \\
\hline 62 & Agrarische arbeiders & -2300 & -2 & relatief laag \\
\hline 63 & Boswachters en bosarbeiders e.d. & -50 & -1 & relatief laag \\
\hline 64 & Vissers, jagers e.d. & -50 & -2 & relatief laag \\
\hline 70 & Leidinggevend produktiepersoneel & -450 & -1 & relatief laag \\
\hline 72 & Hoogoven-, walsers, vormers e.d. & -150 & -1 & relatief laag \\
\hline 73 & Houtzagers, papiermakers e.d. & -200 & -3 & relatief laag \\
\hline 74 & Chemische procesarbeiders e.d. & 250 & 1 & gemiddeld \\
\hline
\end{tabular}




\begin{tabular}{llrll}
\hline CBS & beroepsklasse & aantal & $\%$ & typering \\
& & & & \\
75 & Spinners, wevers, breiers, ververs & -350 & -3 & relatief laag \\
77 & Voedingsmiddelen/drankenbereiders & 3300 & -5 & relatief laag \\
78 & Tabaksbewerkers, -produktenmakers & -250 & -11 & relatief erg laag \\
79 & Kleermakers, kostuumnaaisters e.d. & 400 & 1 & gemiddeld \\
80 & Schoenmakers; lederwarenmakers e.d. & -100 & -1 & relatief laag \\
82 & Meubelmakers e.d.; steenhouwers & 150 & 1 & gemiddeld \\
83 & Smeden, gereedschapmakers e.d. & -3900 & -14 & relatief erg laag \\
84 & Machinebankwerker-monteurs e.d. & 3500 & 2 & gemiddeld \\
85 & Elektromonteurs, -reparateurs & -1100 & -1 & relatief laag \\
87 & Loodgieters, pijpfitters, lassers & 700 & 1 & gemiddeld \\
89 & Glas-, aardewerkvormers e.d. & 0 & -0 & gemiddeld \\
90 & Rubber- en plasticproductenmakers & 150 & 1 & gemiddeld \\
91 & Papierwaren- en kartonnagewerkers & -200 & -4 & relatief laag \\
92 & Drukkers en verwante functies & -2100 & -5 & relatief laag \\
93 & Schilders & 500 & 1 & gemiddeld \\
94 & Ambachts-lindustrieberoepen n.e.g. & 1000 & 7 & gemiddeld \\
95 & Metselaars e.a. bouwvakarbeiders & -3200 & -2 & relatief laag \\
96 & Machinisten, bediener stat. machine & -100 & -2 & relatief laag \\
97 & Laders, lossers, inpakkers e.d. & 46600 & 25 & relatief erg hoog \\
98 & Chauffeurs, matrozen, treinbest. & -1400 & -1 & relatief laag \\
99 & Arbeiders n.e.g. & 500 & 1 & gemiddeld \\
69 & Beroepsmilitairen & 500 & 1 & gemiddeld \\
& Men & & & \\
\hline & & & &
\end{tabular}


Bijlage 2: Vervangingsvraag 1989-1994 per beroepsklasse, absoluut en als percentage van het aantal werkzame personen in 1989

\begin{tabular}{|c|c|c|c|c|}
\hline CBS & beroepsklasse & aantal & $\%$ & typering \\
\hline 01 & Schei- , natuurkundigen e.d. & 5500 & 16 & relatief hoog \\
\hline $02 / 03$ & Architecten, ingenieurs, tekenaars e.d. & 16200 & 8 & relatief laag \\
\hline 04 & Vliegtuig- en scheepsofficieren & 1900 & 14 & gemiddeld \\
\hline 05 & Biologen, biochemici e.d. & 2800 & 9 & relatief laag \\
\hline 06/07 & Genees- en verpleegkundig personeel & 22100 & 8 & relatief laag \\
\hline 08 & Statistici, systeemanalisten e.d. & 1600 & 2 & relatief erg laag \\
\hline 09 & Economen & 1600 & 10 & gemiddeld \\
\hline 11 & Accountants & 1400 & 10 & gemiddeld \\
\hline 12 & Juristen & 1600 & 8 & relatief laag \\
\hline 13 & Leerkrachten & 25300 & 8 & relatief laag \\
\hline 14 & Bedienaars van eredienst e.d. & 1700 & 19 & relatief hoog \\
\hline 15 & Auteurs, journalisten e.d. & 1100 & 4 & relatief erg laag \\
\hline 16 & Beeldhouwers, kunstschilders e.d. & 3700 & 12 & gemiddeld \\
\hline 17 & Musici e.a. uitvoerende kunstenaars & 1300 & 9 & relatief laag \\
\hline 18 & Beroepssportlieden e.d. & 1300 & 14 & gemiddeld \\
\hline 19 & Wetenschappelijk specialist n.e.g. & 8300 & 8 & relatief laag \\
\hline 20 & Leidinggevenden bij openb. bestuur & 550 & 11 & gemiddeld \\
\hline 21 & Leidinggevenden excl. openb. best. & 18700 & 9 & relatief laag \\
\hline 30 & Leidinggevend administratief pers. & 1400 & 8 & relatief laag \\
\hline 31 & Uitvoerende hoofdambtenaren & 400 & 2 & relatief erg laag \\
\hline 32 & Secretaressen, typisten e.d. & 27300 & 18 & relatief hoog \\
\hline 33 & Boekhouders, kassiers e.d. & 38300 & 13 & gemiddeld \\
\hline 34 & Computerapparatuuroperateurs e.d. & 1700 & 14 & gemiddeld \\
\hline 35 & Leidinggevend transportpersoneel & 3300 & 12 & gemiddeld \\
\hline 36 & Conducteurs trein, tram, bus e.d. & 200 & 7 & relatief laag \\
\hline 37 & Post-distributiepersoneel & 4000 & 6 & relatief laag \\
\hline 38 & Telefonisten, telegrafisten e.d. & 2900 & 20 & relatief erg hoog \\
\hline 39 & Administratieve functies n.e.g. & 48100 & 12 & gemiddeld \\
\hline 40 & Directeur/bedr.leiders groothandel & 2800 & 7 & relatief laag \\
\hline 41 & Directeur/bedr.leiders detailhandel & 1500 & 9 & relatief laag \\
\hline 42 & Zelfst. groothandelaren & 2300 & 8 & relatief laag \\
\hline 43 & Zelfst. winkeliers/detailhandelaren & 6900 & 7 & relatief laag \\
\hline 45 & Leidinggevend commercieel personeel & 6900 & 17 & relatief hoog \\
\hline 46 & Vertegenwoordigers, handelsagenten & 5500 & 10 & gemiddeld \\
\hline 47 & Verzekeringsagenten, makelaars e.d. & 4700 & 14 & gemiddeld \\
\hline 48 & Winkelbedienden e.a. verkopers & 55200 & 19 & relatief hoog \\
\hline 50 & Directeur/bedrijfsleider horeca & 1300 & 11 & gemiddeld \\
\hline 51 & Zelfst. hotel-, rest.-, caféhouders & 5100 & 15 & gemiddeld \\
\hline 52 & Leidinggevend huishoudelijk pers. & 1700 & 16 & relatief hoog \\
\hline 53 & Koks, kelners, buffetbediende e.d. & 15900 & 14 & gemiddeld \\
\hline 54 & Huishoudelijk en verz. pers. n.e.g. & 25300 & 15 & gemiddeld \\
\hline 55 & Huisbewaarders, schoonmaakpersoneel & 14900 & 10 & gemiddeld \\
\hline 56 & Wassers, persers e.d. & 2000 & 18 & relatief hoog \\
\hline 57 & Kappers, schoonheidsspecialist e.d. & 4500 & 14 & gemiddeld \\
\hline 58 & Brandweer-, politiepersoneel e.d. & 4500 & 7 & relatief laag \\
\hline 59 & Dienstverlenende functies n.e.g. & 4600 & 14 & gemiddeld \\
\hline 60 & Bedrijfsleiders land- en tuinbouw & 1600 & 21 & relatief erg hoog \\
\hline 61 & Zelfstandige land- en tuinbouwers & 17300 & 13 & gemiddeld \\
\hline 62 & Agrarische arbeiders & 24300 & 18 & relatief hoog \\
\hline 63 & Boswachters en bosarbeiders e.d. & 250 & 6 & relatief laag \\
\hline 64 & Vissers, jagers e.d. & 800 & 22 & relatief erg hoog \\
\hline 70 & Leidinggevend produktiepersoneel & 13600 & 17 & relatief hoog \\
\hline 72 & Hoogoven-, walsers, vormers e.d. & 2000 & 20 & relatief erg hoog \\
\hline 73 & Houtzagers, papiermakers e.d. & 950 & 12 & gemiddeld \\
\hline 74 & Chemische procesarbeiders e.d. & 2900 & 11 & gemiddeld \\
\hline
\end{tabular}




\begin{tabular}{llrrl}
\hline CBS & beroepsklasse & aantal & $\%$ & typering \\
& & & & \\
75 & Spinners, wevers, breiers, ververs & 1000 & 10 & gemiddeld \\
77 & Voedingsmiddelen/drankenbereiders & 9700 & 16 & relatief hoog \\
78 & Tabaksbewerkers, -produktenmakers & 100 & 4 & relatief erg laag \\
79 & Kleermakers, kostuumnaaisters e.d. & 2900 & 9 & relatief laag \\
80 & Schoenmakers; lederwarenmakers e.d. & 1100 & 14 & gemiddeld \\
82 & Meubelmakers e.d.; steenhouwers & 800 & 4 & relatief erg laag \\
83 & Smeden, gereedschapmakers e.d. & 4100 & 14 & gemiddeld \\
84 & Machinebankwerker-monteurs e.d. & 23500 & 14 & gemiddeld \\
85 & Elektromonteurs, -reparateurs & 13100 & 12 & gemiddeld \\
87 & Loodgieters, pijpfitters, lassers & 10900 & 12 & gemiddeld \\
89 & Glas-, aardewerkvormers e.d. & 900 & 10 & gemiddeld \\
90 & Rubber- en plasticproductenmakers & 2100 & 16 & relatief hoog \\
91 & Papierwaren- en kartonnagewerkers & 600 & 11 & gemiddeld \\
92 & Drukkers en verwante functies & 6100 & 14 & gemiddeld \\
93 & Schilders & 2400 & 7 & relatief laag \\
94 & Ambachts-lindustrieberoepen n.e.g. & 800 & 6 & relatief laag \\
95 & Metselaars e.a. bouwvakarbeiders & 14200 & 8 & relatief laag \\
96 & Machinisten, bediener stat. machine & 800 & 13 & gemiddeld \\
97 & Laders, lossers, inpakkers e.d. & 22500 & 12 & gemiddeld \\
98 & Chauffeurs, matrozen, treinbest. & 20800 & 13 & gemiddeld \\
99 & Arbeiders n.e.g. & 2200 & 5 & relatief erg laag \\
69 & Beroepsmilitairen & 9300 & 22 & relatief erg hoog \\
\hline & & & & \\
\hline
\end{tabular}


Bijlage 3: Aantal baanopeningen naar opleidingstype in 1989-1994, absoluut en als percentage van het aantal werkzame personen in 1989 , uitgesplitst in uitbreidings- en vervangingsvraag

\begin{tabular}{|c|c|c|c|c|c|}
\hline Opleidingstype & aantal & $\%$ & typering & $\begin{array}{r}\text { aandeel } \\
\text { verv. } \\
\text { vraag } \\
\%\end{array}$ & $\begin{array}{r}\text { aandeel } \\
\text { uitbr. } \\
\text { vraag } \\
\%\end{array}$ \\
\hline Basisonderwijs & 39200 & 6 & relatief laag & 100 & 0 \\
\hline MAVO en onderbouw HAVO \& VWO & 67000 & 15 & gemiddeld & 64 & 36 \\
\hline LBO Agrarisch & 8100 & 8 & relatief laag & 100 & 0 \\
\hline LBO Technisch & 57100 & 12 & gemiddeld & 100 & 0 \\
\hline LBO Vervoer \& Haven & 6200 & 27 & relatief erg hoog & 32 & 68 \\
\hline LBO Economisch \& Administratief & 11300 & 11 & relatief laag & 100 & 0 \\
\hline LBO Sociale Verzorging \& Horeca & 41100 & 18 & gemiddeld & 85 & 15 \\
\hline LBO Beveiliging \& Bewaking & 300 & 3 & relatief erg laag & 100 & 0 \\
\hline Bovenbouw HAVO \& VWO & 34500 & 15 & gemiddeld & 45 & 55 \\
\hline MBO Agrarisch & 18500 & 17 & gemiddeld & 46 & 54 \\
\hline MBO Technisch \& Laboratorium & 103700 & 18 & gemiddeld & 43 & 57 \\
\hline MBO Vervoer \& Haven \& Telecom & 8100 & 18 & gemiddeld & 40 & 60 \\
\hline MBO Verpleging & 20700 & 21 & relatief hoog & 58 & 42 \\
\hline MBO Medisch Laboratorium & 4500 & 21 & relatief hoog & 52 & 48 \\
\hline MBO Ziekenverzorging & 8700 & 24 & relatief hoog & 60 & 40 \\
\hline MBO Economisch \& Administratief & 227800 & 31 & relatief erg hoog & 15 & 85 \\
\hline MBO Bestuurlijk \& Recht \& Fiscaal & 3800 & 9 & relatief laag & 95 & 5 \\
\hline MBO Sociaal \& Cultureel & 3300 & 12 & gemiddeld & 63 & 37 \\
\hline MBO Sociale Verzorging & 41600 & 29 & relatief erg hoog & 61 & 39 \\
\hline MBO Horeca \& Kappersbedrijf & 6700 & 19 & gemiddeld & 51 & 49 \\
\hline MBO Politie \& Brandweer \& Defensie & 9000 & 16 & gemiddeld & 51 & 49 \\
\hline HBO Docentenopleidingen & 25800 & 12 & gemiddeld & 68 & 32 \\
\hline HBO Tolk \& Vertaler & 350 & 5 & relatief laag & 100 & 0 \\
\hline HBO Theologie & 700 & 19 & gemiddeld & 62 & 38 \\
\hline HBO Agrarisch & 1300 & 11 & relatief laag & 62 & 38 \\
\hline HBO Technisch Laboratorium & 3200 & 15 & gemiddeld & 35 & 65 \\
\hline HBO Technisch & 20500 & 18 & gemiddeld & 36 & 64 \\
\hline HBO Lucht- \& Zeevaart \& Verkeer & 2700 & 11 & relatief laag & 81 & 19 \\
\hline HBO Verpleging \& Fysiotherapie e.d. & 5600 & 12 & gemiddeld & 36 & 64 \\
\hline HBO Medisch Laboratorium & 2700 & 18 & gemiddeld & 53 & 47 \\
\hline HBO Economisch \& Administratief & 34000 & 24 & relatief hoog & 17 & 83 \\
\hline HBO Technische Bedrijfskunde & 1500 & 42 & relatief erg hoog & 12 & 88 \\
\hline HBO Bestuurlijk \& Recht \& Fiscaal & 1700 & 12 & gemiddeld & 56 & 44 \\
\hline HBO Sociaal \& Cultureel & 9800 & 14 & gemiddeld & 42 & 58 \\
\hline HBO Horeca & 750 & 19 & gemiddeld & 43 & 57 \\
\hline HBO Kunst & 1800 & 7 & relatief laag & 100 & 0 \\
\hline HBO Politie \& Brandweer \& Defensie & 850 & 11 & relatief laag & 66 & 34 \\
\hline WO Docentenopleidingen & 1500 & 7 & relatief laag & 60 & 40 \\
\hline WO Letteren \& Geschiedenis e.d. & 1700 & 8 & relatief laag & 65 & 35 \\
\hline WO Theologie & 1300 & 18 & gemiddeld & 81 & 19 \\
\hline WO Agrarisch & 650 & 11 & relatief laag & 53 & 47 \\
\hline WO Wiskunde \& Natuurwetenschappen & 4000 & 14 & gemiddeld & 49 & 51 \\
\hline WO Technisch & 10200 & 21 & relatief hoog & 28 & 72 \\
\hline WO Dier- \& Genees- \& Tandheelkunde & 4400 & 9 & relatief laag & 40 & 60 \\
\hline WO Farmacie & 500 & 13 & gemiddeld & 34 & 66 \\
\hline WO Economie \& Bedrijfskunde (drs) & 10300 & 35 & relatief erg hoog & 17 & 83 \\
\hline WO Econometrie \& Bedrijfskunde (ir) & 3100 & 74 & relatief erg hoog & 5 & 95 \\
\hline WO Rechten \& Bestuurskunde & 3300 & 10 & relatief laag & 56 & 44 \\
\hline WO Sociale Wetenschappen & 4100 & 10 & relatief laag & 59 & 41 \\
\hline WO Kunstwetenschappen & 150 & 9 & relatief laag & 55 & 45 \\
\hline Totaal & 884200 & 17 & gemiddeld & 48 & 52 \\
\hline
\end{tabular}


Bijlage 4: Uitstroom van schoolverlaters, per opleidingstype in 1989-1994, absoluut en als percentage van het aantal werkzame personen in 1989

\begin{tabular}{|c|c|c|c|}
\hline Opleidingstype & aantal & $\%$ & typering \\
\hline Basisonderwijs & 142500 & 23 & gemiddeld \\
\hline MAVO en onderbouw HAVO \& VWO & 37200 & 8 & relatief laag \\
\hline LBO Agrarisch & 10300 & 10 & relatief laag \\
\hline LBO Technisch & 54200 & 11 & relatief laag \\
\hline LBO Vervoer \& Haven & 1000 & 5 & relatief erg laag \\
\hline LBO Economisch \& Administratief & 2900 & 3 & relatief erg laag \\
\hline LBO Sociale Verzorging \& Horeca & 20700 & 9 & relatief laag \\
\hline LBO Beveiliging \& Bewaking & 3000 & 34 & gemiddeld \\
\hline Bovenbouw HAVO \& VWO & 126400 & 54 & relatief hoog \\
\hline MBO Agrarisch & 36700 & 34 & gemiddeld \\
\hline MBO Technisch \& Laboratorium & 157500 & 27 & gemiddeld \\
\hline MBO Vervoer \& Haven \& Telecom & 6300 & 14 & relatief laag \\
\hline MBO Verpleging & 33100 & 34 & gemiddeld \\
\hline MBO Medisch Laboratorium & 3600 & 17 & gemiddeld \\
\hline MBO Ziekenverzorging & 12400 & 34 & gemiddeld \\
\hline MBO Economisch \& Administratief & 132800 & 18 & gemiddeld \\
\hline MBO Bestuurlijk \& Recht \& Fiscaal & 4300 & 11 & relatief laag \\
\hline MBO Sociaal \& Cultureel & 20900 & 74 & relatief hoog \\
\hline MBO Sociale Verzorging & 70300 & 49 & relatief hoog \\
\hline MBO Horeca \& Kappersbedrijf & 9200 & 26 & gemiddeld \\
\hline MBO Politie \& Brandweer \& Defensie & 6500 & 11 & relatief laag \\
\hline HBO Docentenopleidingen & 37900 & 18 & gemiddeld \\
\hline HBO Tolk \& Vertaler & 650 & 9 & relatief laag \\
\hline HBO Theologie & 650 & 18 & gemiddeld \\
\hline HBO Agrarisch & 9200 & 76 & relatief erg hoog \\
\hline HBO Technisch Laboratorium & 4600 & 21 & gemiddeld \\
\hline HBO Technisch & 35800 & 31 & gemiddeld \\
\hline HBO Lucht- \& Zeevaart \& Verkeer & 3100 & 12 & relatief laag \\
\hline HBO Verpleging \& Fysiotherapie e.d. & 28000 & 61 & relatief hoog \\
\hline HBO Medisch Laboratorium & 2500 & 16 & gemiddeld \\
\hline HBO Economisch \& Administratief & 33300 & 23 & gemiddeld \\
\hline HBO Technische Bedrijfskunde & 4100 & 118 & relatief erg hoog \\
\hline HBO Bestuurlijk \& Recht \& Fiscaal & 3200 & 22 & gemiddeld \\
\hline HBO Sociaal \& Cultureel & 26000 & 38 & gemiddeld \\
\hline HBO Horeca & 2100 & 55 & relatief hoog \\
\hline HBO Kunst & 9500 & 38 & gemiddeld \\
\hline HBO Politie \& Brandweer \& Defensie & 1300 & 15 & gemiddeld \\
\hline WO Docentenopleidingen & 2800 & 14 & relatief laag \\
\hline WO Letteren \& Geschiedenis e.d. & 18000 & 83 & relatief erg hoog \\
\hline WO Theologie & 750 & 10 & relatief laag \\
\hline WO Agrarisch & 4200 & 70 & relatief hoog \\
\hline WO Wiskunde \& Natuurwetenschappen & 8100 & 29 & gemiddeld \\
\hline WO Technisch & 17000 & 35 & gemiddeld \\
\hline WO Dier- \& Genees- \& Tandheelkunde & 9400 & 20 & gemiddeld \\
\hline WO Farmacie & 1600 & 41 & relatief hoog \\
\hline WO Economie \& Bedrijfskunde (drs) & 19700 & 68 & relatief hoog \\
\hline WO Econometrie \& Bedrijfskunde (ir) & 3700 & 89 & relatief erg hoog \\
\hline WO Rechten \& Bestuurskunde & 23500 & 73 & relatief hoog \\
\hline WO Sociale Wetenschappen & 22800 & 55 & relatief hoog \\
\hline WO Kunstwetenschappen & 3100 & 164 & relatief erg hoog \\
\hline Totaal & 1233800 & 23 & gemiddeld \\
\hline
\end{tabular}


Basisonderwijs

MAVO en onderbouw HAVO \& VWO

LBO Agrarisch

LBO Technisch

LBO Vervoer \& Haven

LBO Economisch \& Administratief

LBO Sociale Verzorging \& Horeca

LBO Beveiliging \& Bewaking

Bovenbouw HAVO \& VWO

MBO Agrarisch

MBO Technisch \& Laboratorium

MBO Vervoer \& Haven \& Telecom

MBO Verpleging

MBO Medisch Laboratorium

MBO Ziekenverzorging

MBO Economisch \& Administratief

MBO Bestuurlijk \& Recht \& Fiscaal

MBO Sociaal \& Cultureel

MBO Sociale Verzorging

MBO Horeca \& Kappersbedrijf

MBO Politie \& Brandweer \& Defensie

HBO Docentenopleidingen

HBO Tolk \& Vertaler

HBO Theologie

HBO Agrarisch

HBO Technisch Laboratorium

HBO Technisch

HBO Lucht- \& Zeevaart \& Verkeer

HBO Verpleging \& Fysiotherapie e.d.

HBO Medisch Laboratorium

HBO Economisch \& Administratief

HBO Technische Bedrijfskunde

HBO Bestuurlijk \& Recht \& Fiscaal

HBO Sociaal \& Cultureel

HBO Horeca

HBO Kunst

HBO Politie \& Brandweer \& Defensie

WO Docentenopleidingen

WO Letteren \& Geschiedenis e.d.

WO Theologie

WO Agrarisch

WO Wiskunde \& Natuurwetenschappen

WO Technisch

WO Dier- \& Genees- \& Tandheelkunde

WO Farmacie

WO Economie \& Bedrijfskunde (drs)

WO Econometrie \& Bedrijfskunde (ir)

WO Rechten \& Bestuurskunde

WO Sociale Wetenschappen

WO Kunstwetenschappen
1.52

1.01

1.07

1.11

0.84

1.26

0.99

1.43

1.44

1.15

1.09

0.98

1.14

1.01

1.10

0.91

1.02

1.63

1.19

1.08

1.01

1.08

1.25

1.00

1.64

1.07

1.13

1.04

1.47

1.00

1.00

1.55

1.12

1.27

1.33

1.49

1.09

1.08

1.80

0.95

1.64

1.18

1.13

1.13

1.27

1.26

1.10

1.62

1.48

2.62 slecht arbeidsmarktperspectief goed arbeidsmarktperspectief redelijk arbeidsmarktperspectief redelijk arbeidsmarktperspectief goed arbeidsmarktperspectief matig arbeidsmarktperspectief goed arbeidsmarktperspectief slecht arbeidsmarktperspectief slecht arbeidsmarktperspectief redelijk arbeidsmarktperspectief redelijk arbeidsmarktperspectief goed arbeidsmarktperspectief redelijk arbeidsmarktperspectief goed arbeidsmarktperspectief redelijk arbeidsmarktperspectief goed arbeidsmarktperspectief goed arbeidsmarktperspectief slecht arbeidsmarktperspectief matig arbeidsmarktperspectief redelijk arbeidsmarktperspectief goed arbeidsmarktperspectief redelijk arbeidsmarktperspectief matig arbeidsmarktperspectief goed arbeidsmarktperspectief slecht arbeidsmarktperspectief redelijk arbeidsmarktperspectief redelijk arbeidsmarktperspectief goed arbeidsmarktperspectief slecht arbeidsmarktperspectief goed arbeidsmarktperspectief goed arbeidsmarktperspectief slecht arbeidsmarktperspectief redelijk arbeidsmarktperspectief matig arbeidsmarktperspectief matig arbeidsmarktperspectief slecht arbeidsmarktperspectief redelijk arbeidsmarktperspectief redelijk arbeidsmarktperspectief slecht arbeidsmarktperspectief goed arbeidsmarktperspectief slecht arbeidsmarktperspectief matig arbeidsmarktperspectief redelijk arbeidsmarktperspectief redelijk arbeidsmarktperspectief matig arbeidsmarktperspectief matig arbeidsmarktperspectief redelijk arbeidsmarktperspectief slecht arbeidsmarktperspectief slecht arbeidsmarktperspectief slecht arbeidsmarktperspectief 
Bijlage 6: Het aandeel werknemers jonger dan 30 jaar en de conjunctuurgevoeligheid $\left(\mathrm{FI}_{\mathrm{b}}\right)$ per beroepsklasse

\begin{tabular}{|c|c|c|c|c|c|}
\hline CBS & beroepsklasse & $\begin{array}{l}\text { ndeel } \\
30 \text { jaar }\end{array}$ & typering & $\mathrm{FI}_{\mathrm{b}}$ & typering \\
\hline 01 & Schei- , natuurkundigen e.d. & 0.37 & gemiddeld & 1.72 & gemiddeld \\
\hline $02 / 03$ & Architecten, ingenieurs, tekenaars e.d. & 0.20 & relatief klein & 2.12 & relatief groot \\
\hline 04 & Vliegtuig- en scheepsofficieren & 0.26 & gemiddeld & 1.25 & relatief klein \\
\hline 05 & Biologen, biochemici e.d. & 0.42 & relatief groot & 1.48 & gemiddeld \\
\hline 06/07 & Genees- en verpleegkundig personeel & 0.52 & relatief erg groot & 1.65 & gemiddeld \\
\hline 08 & Statistici, systeemanalisten e.d. & 0.36 & gemiddeld & 1.66 & gemiddeld \\
\hline 09 & Economen & 0.18 & relatief klein & 1.55 & gemiddeld \\
\hline 11 & Accountants & 0.12 & relatief erg klein & 1.33 & relatief klein \\
\hline 12 & Juristen & 0.21 & relatief klein & 1.25 & relatief klein \\
\hline 13 & Leerkrachten & 0.23 & relatief klein & 1.03 & relatief klein \\
\hline 14 & Bedienaars van eredienst e.d. & 0.09 & relatief erg klein & 1.53 & gemiddeld \\
\hline 15 & Auteurs, journalisten e.d. & 0.24 & relatief klein & 1.70 & gemiddeld \\
\hline 16 & Beeldhouwers, kunstschilders e.d. & 0.25 & relatief klein & 1.58 & gemiddeld \\
\hline 17 & Musici e.a. uitvoerende kunstenaars & 0.30 & gemiddeld & 1.51 & gemiddeld \\
\hline 18 & Beroepssportlieden e.d. & 0.37 & gemiddeld & 1.51 & gemiddeld \\
\hline 19 & Wetenschappelijk specialist n.e.g. & 0.25 & relatief klein & 1.41 & relatief klein \\
\hline 20 & Leidinggevenden bij openb. bestuur & 0.00 & relatief erg klein & 1.07 & relatief klein \\
\hline 21 & Leidinggevenden excl. openb. best. & 0.05 & relatief erg klein & 2.06 & relatief groot \\
\hline 30 & Leidinggevend administratief pers. & 0.14 & relatief erg klein & 1.48 & gemiddeld \\
\hline 31 & Uitvoerende hoofdambtenaren & 0.02 & relatief erg klein & 1.04 & relatief klein \\
\hline 32 & Secretaressen, typisten e.d. & 0.52 & relatief erg groot & 1.58 & gemiddeld \\
\hline 33 & Boekhouders, kassiers e.d. & 0.46 & relatief groot & 1.53 & gemiddeld \\
\hline 34 & Computerapparatuuroperateurs e.d. & 0.48 & relatief groot & 1.62 & gemiddeld \\
\hline 35 & Leidinggevend transportpersoneel & 0.12 & relatief erg klein & 1.37 & relatief klein \\
\hline 36 & Conducteurs trein, tram, bus e.d. & 0.33 & gemiddeld & 1.12 & relatief klein \\
\hline 37 & Post-distributiepersoneel & 0.38 & gemiddeld & 1.20 & relatief klein \\
\hline 38 & Telefonisten, telegrafisten e.d. & 0.40 & gemiddeld & 1.47 & gemiddeld \\
\hline 39 & Administratieve functies n.e.g. & 0.43 & relatief groot & 1.52 & gemiddeld \\
\hline 40 & Directeur/bedr.leiders groothandel & 0.06 & relatief erg klein & 1.43 & relatief klein \\
\hline 41 & Directeur/bedr.leiders detailhandel & 0.14 & relatief erg klein & 1.43 & relatief klein \\
\hline 42 & Zelfst. groothandelaren & 0.13 & relatief erg klein & 1.43 & relatief klein \\
\hline 43 & Zelfst. winkeliers/detailhandelaren & 0.12 & relatief erg klein & 1.43 & relatief klein \\
\hline 45 & Leidinggevend commercieel personeel & 0.25 & relatief klein & 1.68 & gemiddeld \\
\hline 46 & Vertegenwoordigers, handelsagenten & 0.19 & relatief klein & 1.71 & gemiddeld \\
\hline 47 & Verzekeringsagenten, makelaars e.d. & 0.21 & relatief klein & 1.46 & gemiddeld \\
\hline 48 & Winkelbedienden e.a. verkopers & 0.53 & relatief erg groot & 1.46 & gemiddeld \\
\hline 50 & Directeur/bedrijfsleider horeca & 0.00 & relatief erg klein & 1.46 & gemiddeld \\
\hline 51 & Zelfst. hotel-, rest.-, caféhouders & 0.19 & relatief klein & 1.30 & relatief klein \\
\hline 52 & Leidinggevend huishoudelijk pers. & 0.15 & relatief erg klein & 1.55 & gemiddeld \\
\hline 53 & Koks, kelners, buffetbediende e.d. & 0.20 & relatief klein & 1.45 & relatief klein \\
\hline 54 & Huishoudelijk en verz. pers. n.e.g. & 0.50 & relatief groot & 1.52 & gemiddeld \\
\hline 55 & Huisbewaarders, schoonmaakpersoneel & 0.37 & gemiddeld & 1.38 & relatief klein \\
\hline 56 & Wassers, persers e.d. & 0.22 & relatief klein & 1.53 & gemiddeld \\
\hline 57 & Kappers, schoonheidsspecialist e.d. & 0.44 & relatief groot & 1.32 & relatief klein \\
\hline 58 & Brandweer-, politiepersoneel e.d. & 0.53 & relatief erg groot & 1.17 & relatief klein \\
\hline 59 & Dienstverlenende functies n.e.g. & 0.36 & gemiddeld & 1.63 & gemiddeld \\
\hline 60 & Bedrijfsleiders land- en tuinbouw & 0.48 & relatief groot & 1.20 & relatief klein \\
\hline 61 & Zelfstandige land- en tuinbouwers & 0.12 & relatief erg klein & 0.97 & relatief erg klein \\
\hline 62 & Agrarische arbeiders & 0.40 & gemiddeld & 1.15 & relatief klein \\
\hline 63 & Boswachters en bosarbeiders e.d. & 0.24 & relatief klein & 1.45 & relatief klein \\
\hline 64 & Vissers, jagers e.d. & 0.38 & gemiddeld & 1.01 & relatief klein \\
\hline 70 & Leidinggevend produktiepersoneel & 0.10 & relatief erg klein & 2.46 & relatief groot \\
\hline 72 & Hoogoven-, walsers, vormers e.d. & 0.38 & gemiddeld & 2.58 & relatief erg groot \\
\hline 73 & Houtzagers, papiermakers e.d. & 0.37 & gemiddeld & 1.98 & gemiddeld \\
\hline 74 & Chemische procesarbeiders e.d. & 0.37 & gemiddeld & 2.35 & relatief groot \\
\hline 75 & Spinners, wevers, breiers, ververs & 0.34 & gemiddeld & 3.91 & relatief erg groot \\
\hline
\end{tabular}




\begin{tabular}{llllll}
\hline CBS & beroepsklasse & $\begin{array}{c}\text { aandeel } \\
<30 \text { jaar }\end{array}$ & typering & $\mathrm{FI}_{\mathrm{b}}$ & typering \\
& & & & & \\
& & & & & \\
77 & Voedingsmiddelen/drankenbereiders & 0.50 & relatief groot & 1.16 & relatief klein \\
78 & Tabaksbewerkers, -produktenmakers & 0.49 & relatief groot & 1.09 & relatief klein \\
79 & Kleermakers, kostuumnaaisters e.d. & 0.41 & relatief groot & 3.12 & relatief erg groot \\
80 & Schoenmakers; lederwarenmakers e.d. & 0.40 & gemiddeld & 3.33 & relatief erg groot \\
82 & Meubelmakers e.d.; steenhouwers & 0.35 & gemiddeld & 2.25 & relatief groot \\
83 & Smeden, gereedschapmakers e.d. & 0.40 & gemiddeld & 2.62 & relatief erg groot \\
84 & Machinebankwerker-monteurs e.d. & 0.44 & relatief groot & 1.95 & gemiddeld \\
85 & Elektromonteurs, -reparateurs & 0.38 & gemiddeld & 2.70 & relatief erg groot \\
87 & Loodgieters, pijpfitters, lassers & 0.41 & relatief groot & 2.69 & relatief erg groot \\
89 & Glas-, aardewerkvormers e.d. & 0.40 & gemiddeld & 2.30 & relatief groot \\
90 & Rubber- en plasticproductenmakers & 0.45 & relatief groot & 2.49 & relatief groot \\
91 & Papierwaren- en kartonnagewerkers & 0.41 & relatief groot & 2.05 & gemiddeld \\
92 & Drukkers en verwante functies & 0.44 & relatief groot & 2.03 & gemiddeld \\
93 & Schilders & 0.41 & relatief groot & 2.96 & relatief erg groot \\
94 & Ambachts-lindustrieberoepen n.e.g. & 0.36 & gemiddeld & 2.32 & relatief groot \\
95 & Metselaars e.a. bouwvakarbeiders & 0.39 & gemiddeld & 3.26 & relatief erg groot \\
96 & Machinisten, bediener stat. machine & 0.36 & gemiddeld & 2.04 & gemiddeld \\
97 & Laders, lossers, inpakkers e.d. & 0.13 & relatief erg klein & 1.85 & gemiddeld \\
98 & Chauffeurs, matrozen, treinbest. & 0.41 & relatief groot & 1.35 & relatief klein \\
99 & Arbeiders n.e.g. & 0.28 & gemiddeld & 2.66 & relatief erg groot \\
69 & Beroepsmilitairen & 0.44 & relatief groot & 1.01 & relatief klein \\
& & & & &
\end{tabular}


Bijlage 7: Het relatief aanzien en het gewogen functieniveau per beroepsklasse

\begin{tabular}{|c|c|c|c|c|}
\hline CBS & beroepsklasse & $\begin{array}{l}\text { relatief } \\
\text { aanzien }\end{array}$ & typering & $\begin{array}{l}\text { gewogen } \\
\text { functieniveau }\end{array}$ \\
\hline 01 & Schei-, natuurkundigen e.d. & 0.68 & relatief hoog & 4.9 \\
\hline $02 / 03$ & Architecten, ingenieurs, tekenaars e.d. & 0.37 & gemiddeld & 5.5 \\
\hline 04 & Vliegtuig- en scheepsofficieren & 1.56 & relatief erg hoog & 4.6 \\
\hline 05 & Biologen, biochemici e.d. & 0.99 & relatief hoog & 5.4 \\
\hline 06/07 & Genees- en verpleegkundig personeel & 0.97 & relatief hoog & 5.0 \\
\hline 08 & Statistici, systeemanalisten e.d. & 1.18 & relatief hoog & 6.0 \\
\hline 09 & Economen & 1.41 & relatief erg hoog & 6.0 \\
\hline 11 & Accountants & 1.15 & relatief hoog & 6.2 \\
\hline 12 & Juristen & 2.13 & relatief erg hoog & 7.0 \\
\hline 13 & Leerkrachten & 1.12 & relatief hoog & 6.4 \\
\hline 14 & Bedienaars van eredienst e.d. & 1.15 & relatief hoog & 5.7 \\
\hline 15 & Auteurs, journalisten e.d. & 1.00 & relatief hoog & 5.6 \\
\hline 16 & Beeldhouwers, kunstschilders e.d. & 0.01 & gemiddeld & 4.9 \\
\hline 17 & Musici e.a. uitvoerende kunstenaars & 0.22 & gemiddeld & 5.4 \\
\hline 18 & Beroepssportlieden e.d. & 0.32 & gemiddeld & 5.0 \\
\hline 19 & Wetenschappelijk specialist n.e.g. & 1.05 & relatief hoog & 5.8 \\
\hline 20 & Leidinggevenden bij openb. bestuur & 2.18 & relatief erg hoog & 6.4 \\
\hline 21 & Leidinggevenden excl. openb. best. & 2.08 & relatief erg hoog & 6.0 \\
\hline 30 & Leidinggevend administratief pers. & 1.00 & relatief hoog & 5.0 \\
\hline 31 & Uitvoerende hoofdambtenaren & 1.25 & relatief hoog & 6.1 \\
\hline 32 & Secretaressen, typisten e.d. & 0.22 & gemiddeld & 3.6 \\
\hline 33 & Boekhouders, kassiers e.d. & 0.53 & relatief hoog & 3.5 \\
\hline 34 & Computerapparatuuroperateurs e.d. & 0.89 & relatief hoog & 4.4 \\
\hline 35 & Leidinggevend transportpersoneel & 0.22 & gemiddeld & 3.5 \\
\hline 36 & Conducteurs trein, tram, bus e.d. & -0.30 & gemiddeld & 2.0 \\
\hline 37 & Post-distributiepersoneel & -0.92 & relatief laag & 1.7 \\
\hline 38 & Telefonisten, telegrafisten e.d. & -0.71 & relatief laag & 3.1 \\
\hline 39 & Administratieve functies n.e.g. & -0.40 & gemiddeld & 2.8 \\
\hline 40 & Directeur/bedr.leiders groothandel & 1.72 & relatief erg hoog & 6.0 \\
\hline 41 & Directeur/bedr.leiders detailhandel & 0.37 & gemiddeld & 6.0 \\
\hline 42 & Zelfst. groothandelaren & 1.00 & relatief hoog & 5.0 \\
\hline 43 & Zelfst. winkeliers/detailhandelaren & 0.22 & gemiddeld & 5.0 \\
\hline 45 & Leidinggevend commercieel personeel & 0.37 & gemiddeld & 5.2 \\
\hline 46 & Vertegenwoordigers, handelsagenten & 0.32 & gemiddeld & 4.2 \\
\hline 47 & Verzekeringsagenten, makelaars e.d. & 0.58 & relatief hoog & 4.1 \\
\hline 48 & Winkelbedienden e.a. verkopers & -1.39 & relatief erg laag & 2.1 \\
\hline 50 & Directeur/bedrijfsleider horeca & 0.89 & relatief hoog & 4.1 \\
\hline 51 & Zelfst. hotel-, rest.-, caféhouders & 0.22 & gemiddeld & 4.0 \\
\hline 52 & Leidinggevend huishoudelijk pers. & -0.40 & gemiddeld & 5.0 \\
\hline 53 & Koks, kelners, buffetbediende e.d. & -0.61 & relatief laag & 2.2 \\
\hline 54 & Huishoudelijk en verz. pers. n.e.g. & -1.02 & relatief laag & 2.8 \\
\hline 55 & Huisbewaarders, schoonmaakpersoneel & -1.59 & relatief erg laag & 1.3 \\
\hline 56 & Wassers, persers e.d. & -1.59 & relatief erg laag & 1.1 \\
\hline 57 & Kappers, schoonheidsspecialist e.d. & -0.19 & gemiddeld & 3.8 \\
\hline 58 & Brandweer-, politiepersoneel e.d. & 0.51 & relatief hoog & 3.1 \\
\hline 59 & Dienstverlenende functies n.e.g. & -0.04 & gemiddeld & 3.0 \\
\hline 60 & Bedrijfsleiders land- en tuinbouw & 0.22 & gemiddeld & 5.0 \\
\hline 61 & Zelfstandige land- en tuinbouwers & -0.50 & gemiddeld & 5.0 \\
\hline 62 & Agrarische arbeiders & -0.97 & relatief laag & 2.1 \\
\hline 63 & Boswachters en bosarbeiders e.d. & -0.61 & relatief laag & 2.5 \\
\hline 64 & Vissers, jagers e.d. & -0.81 & relatief laag & 2.2 \\
\hline 69 & Beroepsmilitairen & 1.10 & relatief hoog & 6.0 \\
\hline 70 & Leidinggevend produktiepersoneel & 0.17 & gemiddeld & 4.8 \\
\hline 72 & Hoogoven-, walsers, vormers e.d. & -1.12 & relatief laag & 1.7 \\
\hline 73 & Houtzagers, papiermakers e.d. & -1.38 & relatief erg laag & 1.8 \\
\hline
\end{tabular}




\begin{tabular}{lllll}
\hline CBS & beroepsklasse & relatief & typering & $\begin{array}{c}\text { gewogen } \\
\text { functieniveau }\end{array}$ \\
& & & & \\
& & & & 2.4 \\
74 & Chemische procesarbeiders e.d. & -0.30 & gemiddeld & 2.1 \\
75 & Spinners, wevers, breiers, ververs & -0.87 & relatief laag & 2.4 \\
77 & Voedingsmiddelen/drankenbereiders & -1.54 & relatief erg laag & 1.3 \\
78 & Tabaksbewerkers, -produktenmakers & -0.87 & relatief laag & 2.2 \\
79 & Kleermakers, kostuumnaaisters e.d. & -0.71 & relatief laag & 1.9 \\
80 & Schoenmakers; lederwarenmakers e.d. & -1.32 & relatief erg laag & 2.5 \\
82 & Meubelmakers e.d.; steenhouwers & -0.61 & relatief laag & 2.5 \\
83 & Smeden, gereedschapmakers e.d. & -0.45 & gemiddeld & 3.9 \\
84 & Machinebankwerker-monteurs e.d. & -0.81 & relatief laag & 3.8 \\
85 & Elektromonteurs, -reparateurs & 0.32 & gemiddeld & 3.3 \\
87 & Loodgieters, pijpfitters, lassers & -1.12 & relatief laag & 1.4 \\
89 & Glas-, aardewerkvormers e.d. & -1.38 & relatief erg laag & 1.3 \\
90 & Rubber- en plasticproductenmakers & -1.38 & relatief erg laag & 1.0 \\
91 & Papierwaren- en kartonnagewerkers & -1.38 & relatief erg laag & 2.7 \\
92 & Drukkers en verwante functies & -0.35 & gemiddeld & 2.8 \\
93 & Schilders & -0.97 & relatief laag & 1.7 \\
94 & Ambachts-lindustrieberoepen n.e.g. & -0.61 & relatief laag & 3.3 \\
95 & Metselaars e.a. bouwvakarbeiders & -0.92 & relatief laag & 2.4 \\
96 & Machinisten, bediener stat. machine & -0.30 & gemiddeld & 1.3 \\
97 & Laders, lossers, inpakkers e.d. & -0.30 & gemiddeld & 2.0 \\
98 & Chauffeurs, matrozen, treinbest. & -0.76 & relatief laag & 1.0 \\
99 & Arbeiders n.e.g. & -1.64 & relatief erg laag & 3.7 \\
& & & & \\
& Gemiddelde & 0.01 & gemiddeld & \\
\hline
\end{tabular}


Bijlage 8: Het werkloosheidspercentage en de uitwijkmogelijkheden op aansluitend functieniveau (GH)

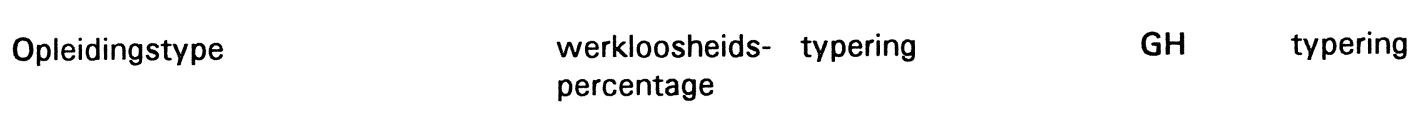

Basisonderwijs

MAVO en onderbouw HAVO \& VWO

LBO Agrarisch

LBO Technisch

LBO Vervoer \& Haven

LBO Economisch \& Administratief

LBO Sociale Verzorging \& Horeca

BovenbouW HAVO \& VWO

MBO Agrarisch

MBO Technisch \& Laboratorium

MBO Vervoer \& Haven \& Telecom

MBO Verpleging

MBO Medisch Laboratorium

MBO Ziekenverzorging

MBO Economisch \& Administratief

MBO Bestuurlijk \& Recht \& Fiscaal

MBO Sociaal \& Cultureel

MBO Sociale Verzorging

MBO Horeca \& Kappersbedrijf

MBO Politie \& Brandweer \& Defensie

HBO Docentenopleidingen *

HBO Tolk \& Vertaler

HBO Theologie

HBO Agrarisch

HBO Technisch Laboratorium* *

HBO Technisch

HBO Lucht- \& Zeevaart \& Verkeer

HBO Verpleging \& Fysiotherapie e.d.

HBO Medisch Laboratorium * *

HBO Economisch \& Administratief

HBO Technische Bedrijfskunde

HBO Bestuurlijk \& Recht \& Fiscaal

HBO Sociaal \& Cultureel

HBO Horeca

HBO Kunst

HBO Politie \& Brandweer \& Defensie

WO Docentenopleidingen*

WO Letteren \& Geschiedenis e.d.

WO Theologie

WO Agrarisch

WO Wiskunde \& Natuurwetenschappen

WO Technisch

WO Dier- \& Genees- \& Tandheelkunde

WO Farmacie

WO Economie \& Bedrijfskunde (drs)

WO Econometrie \& Bedrijfskunde (ir)

WO Rechten \& Bestuurskunde

WO Sociale Wetenschappen

WO Kunstwetenschappen relatief erg hoog

relatief hoog

relatief laag

gemiddeld

relatief laag

relatief hoog

relatief hoog

relatief erg hoog

relatief erg laag

relatief erg laag

relatief erg laag

relatief laag

relatief erg laag

relatief laag

relatief erg laag

relatief erg laag

relatief hoog

relatief laag

relatief laag

relatief erg laag

relatief laag

gemiddeld

relatief erg laag

relatief laag

relatief erg laag

relatief erg laag

relatief erg laag

relatief laag

relatief erg laag

relatief erg laag

relatief laag

relatief laag

relatief hoog

relatief laag

relatief erg hoog

relatief erg laag

relatief laag

relatief erg hoog

relatief erg laag

relatief hoog

gemiddeld

relatief erg laag

relatief laag

relatief erg laag

relatief laag

relatief erg laag

gemiddeld

relatief hoog

relatief erg hoog
0.84 relatief groot

0.73 gemiddeld

0.82 relatief groot

0.29 relatief erg klein

0.82 relatief groot

0.54 relatief erg klein

0.83 relatief groot

0.74 gemiddeld

0.86 relatief groot

0.74 gemiddeld

0.67 gemiddeld

0.75 gemiddeld

0.51 relatief erg klein

0.86 relatief groot

0.77 gemiddeld

0.79 gemiddeld

0.63 relatief klein

0.78 gemiddeld

0.38 relatief erg klein

0.77 gemiddeld

0.80 gemiddeld

0.51 relatief erg klein

0.90 relatief groot

0.80 gemiddeld

0.95 relatief erg groot

0.77 gemiddeld

0.73 gemiddeld

0.70 gemiddeld

0.67 gemiddeld

0.91 relatief erg groot

0.78 gemiddeld

0.79 gemiddeld

0.79 gemiddeld

0.85 relatief groot

0.59 relatief klein

0.47 relatief erg klein

0.65 relatief klein

0.55 relatief erg klein

0.89 relatief groot

0.91 relatief erg groot

0.95 relatief erg groot

0.55 relatief erg klein

0.71 gemiddeld

0.90 relatief groot

0.86 relatief groot

0.83 relatief groot

0.80 gemiddeld

0.81 relatief groot

* Werkloosheid bepaald voor WO en HBO gezamenlijk

* Werkloosheid bepaald voor technisch en medisch laboratotium gezamenlijk 
Bijlage 9: Onderbenutting en het gemiddelde functieniveau per opleidingstype in 1985 en het gemiddelde functieniveau

\begin{tabular}{|c|c|c|c|}
\hline & $\begin{array}{c}\text { onderbenutting } \\
\%\end{array}$ & typering & $\begin{array}{l}\text { gemiddeld } \\
\text { functieniveau }\end{array}$ \\
\hline Basisonderwijs & - & & 2.4 \\
\hline MAVO en onderbouw HAVO \& VWO & 38 & gemiddeld & 3.0 \\
\hline LBO Agragrisch & 35 & gemiddeld & 3.7 \\
\hline LBO Technisch & 41 & gemiddeld & 3.0 \\
\hline LBO Vervoer \& Haven & 85 & relatief erg hoog & 2.2 \\
\hline LBO Economisch \& Administratief & 36 & gemidddeld & 3.0 \\
\hline LBO Sociale Verzorging \& Horeca & 67 & relatief erg hoog & 2.4 \\
\hline LBO Beveiliging \& Bewaking & 89 & relatief erg hoog & 2.4 \\
\hline Bovenbouw HAVO \& VWO & 49 & relatief hoog & 3.8 \\
\hline MBO Agrarisch & 38 & gemiddeld & 3.9 \\
\hline MBO Technisch \& Laboratorium & 37 & gemiddeld & 3.7 \\
\hline MBO Vervoer \& Haven \& Telecom & 63 & relatief erg hoog & 3.3 \\
\hline MBO Verpleging & 15 & relatief laag & 4.6 \\
\hline MBO Medisch Laboratorium & 12 & relatief laag & 4.2 \\
\hline MBO Ziekenverzorging & 22 & relatief laag & 3.7 \\
\hline MBO Economisch \& Administratief & 46 & relatief hoog & 3.8 \\
\hline MBO Bestuurlijk \& Recht \& Fiscaal & 44 & gemiddeld & 3.8 \\
\hline MBO Sociaal \& Cultureel & 40 & gemiddeld & 4.2 \\
\hline MBO Sociale Verzorging & 61 & relatief hoog & 3.3 \\
\hline MBO Horeca \& Kappersbedrijf & 26 & gemiddeld & 3.6 \\
\hline MBO Politie \& Brandweer \& Defensie & 79 & relatief erg hoog & 3.1 \\
\hline HBO Docentenopleidingen & 12 & relatief laag & 5.8 \\
\hline HBO Tolk \& Vertaler & 36 & gemiddeld & 5.2 \\
\hline HBO Theologie & 13 & relatief laag & 5.7 \\
\hline HBO Agrarisch & 21 & relatief laag & 5.2 \\
\hline HBO Technisch Laboratorium & 53 & relatief hoog & 4.8 \\
\hline HBO Technisch & 15 & relatief laag & 5.4 \\
\hline HBO Lucht- \& Zeevaart \& Verkeer & 46 & relatief hoog & 4.6 \\
\hline HBO Verpleging \& Fysiotherapie e.d. & 6 & relatief laag & 5.2 \\
\hline HBO Medisch Laboratorium & 17 & relatief laag & 4.8 \\
\hline HBO Economisch \& Administratief & 56 & relatief hoog & 4.5 \\
\hline HBO Technische Bedrijfskunde & 19 & relatief laag & 5.3 \\
\hline HBO Bestuurlijk \& Recht \& Fiscaal & 40 & gemiddeld & 4.9 \\
\hline HBO Sociaal \& Cultureel & 20 & relatief laag & 5.1 \\
\hline HBO Horeca & 40 & gemiddeld & 4.6 \\
\hline HBO Kunst & 11 & relatief laag & 5.3 \\
\hline HBO Politie \& Brandweer \& Defensie & 62 & relatief erg hoog & 3.8 \\
\hline WO Docentenopleidingen & 7 & relatief laag & 6.4 \\
\hline WO Letteren \& Geschiedenis e.d. & 9 & relatief laag & 6.2 \\
\hline WO Theologie & 13 & relatief laag & 5.8 \\
\hline WO Agrarisch & 23 & gemiddeld & 5.8 \\
\hline WO Wiskunde \& Natuurwetenschappen & 9 & relatief laag & 6.5 \\
\hline WO Technisch & 14 & relatief laag & 6.2 \\
\hline WO Dier- \& Genees- \& Tandheelkunde & 4 & relatief erg laag & 6.8 \\
\hline WO Farmacie & 4 & relatief erg laag & 6.8 \\
\hline WO Informatica,Economie,Bedrijfsk. & 15 & relatief laag & 5.8 \\
\hline WO Econometrie \& Bedrijfskunde (ir) & 39 & gemiddeld & 5.7 \\
\hline WO Rechten \& Bestuurskunde & 15 & relatief laag & 6.2 \\
\hline WO Sociale Wetenschappen & 25 & gemiddeld & 6.0 \\
\hline WO Kunstwetenschappen & 42 & gemiddeld & 5.6 \\
\hline
\end{tabular}


Bijlage 10: De belangrijkste opleidingsachtergronden van de beroepsbeoefenaren in vrouwenberoepen naar sexe in 1985 (tussen haakjes: in procenten)

\begin{tabular}{|c|c|c|c|}
\hline Vrouwe & beroep & Mannen & Vrouwen \\
\hline 06/07 & $\begin{array}{l}\text { Genees- en } \\
\text { verpleegkundigen }\end{array}$ & $\begin{array}{l}\text { WO Dier-, Geneeskunde, Tandheel- } \\
\text { kunde (33) } \\
\text { MBO Verpleging (18) } \\
\text { HBO Verpleging, Fysiotherapie e.d. } \\
\text { (18) }\end{array}$ & $\begin{array}{l}\text { MBO Verpleging (28) } \\
\text { HBO Verpleging, Fysiotherapie e.d. } \\
\text { (14) } \\
\text { MBO Sociale verzorging (13) } \\
\text { MBO Ziekenverzorging (13) }\end{array}$ \\
\hline 32 & $\begin{array}{l}\text { Secretaressen, } \\
\text { Typisten }\end{array}$ & $\begin{array}{l}\text { MBO Economisch \& Administratief } \\
\text { (23) } \\
\text { MAVO, onderbouw HAVO/VWO } \\
\text { (19) } \\
\text { Bovenbouw HAVO/VWO (12) }\end{array}$ & $\begin{array}{l}\text { MBO Economisch + Administra- } \\
\text { tief (31) } \\
\text { HBO Economisch + Administratief } \\
\text { (15) } \\
\text { MAVO, onderbouw HAVO/VWO } \\
\text { (15) } \\
\text { Bovenbouw HAVO/VWO (11) } \\
\text { LBO Economisch + Administratief } \\
\text { (10) }\end{array}$ \\
\hline 38 & $\begin{array}{l}\text { Telefonisten, } \\
\text { telegrafisten }\end{array}$ & $\begin{array}{l}\text { HBO Verkeer, Vervoer + Telecom- } \\
\text { municatie (16) } \\
\text { MBO Politie-, Defensie-, Bewa- } \\
\text { kingsopleiding (14) } \\
\text { MAVO, onderbouw HAVO/VWO } \\
\text { (14) } \\
\text { Bovenbouw HAVO/VWO (13) }\end{array}$ & $\begin{array}{l}\text { MAVO, onderbouw HAVO/VWO } \\
(28) \\
\text { MBO Economisch + Administra- } \\
\text { tief (15) } \\
\text { Bovenbouw HAVO/VWO (12) }\end{array}$ \\
\hline 48 & Winkelbedienden & $\begin{array}{l}\text { MBO Economisch + Administratief } \\
\text { (25) } \\
\text { Basisonderwijs (15) } \\
\text { MAVO, onderbouw HAVO/VWO } \\
\text { (15) } \\
\text { LBO Technisch (12) }\end{array}$ & $\begin{array}{l}\text { LBO Sociale verzorging + Horeca } \\
(22) \\
\text { Basisonderwijs (17) } \\
\text { MAVO, onderbouw HAVO/VWO } \\
\text { (16) } \\
\text { MBO Economisch + Administra- } \\
\text { tief (14) }\end{array}$ \\
\hline 53 & $\begin{array}{l}\text { Koks, kelners, } \\
\text { serveersters e.d. }\end{array}$ & $\begin{array}{l}\text { LBO Sociale Verzorging en Horeca } \\
\text { (33) } \\
\text { Basisonderwijs (21) } \\
\text { LBO Technisch (10) } \\
\text { MAVO, onderbouw HAVO/VWO } \\
\text { (7) }\end{array}$ & $\begin{array}{l}\text { LBO Sociale Verzorging en Horeca } \\
\text { (28) } \\
\text { Basisonderwijs (28) } \\
\text { MAVO, onderbouw HAVO/VWO } \\
(11) \\
\text { MBO Sociale Verzorging (10) }\end{array}$ \\
\hline 54 & $\begin{array}{l}\text { Huishoudelijk en } \\
\text { verzorgend perso- } \\
\text { neel }\end{array}$ & $\begin{array}{l}\text { Bovenbouw HAVO/VWO (11) } \\
\text { LBO Technisch (11) }\end{array}$ & $\begin{array}{l}\text { MBO Sociale verzorging (25) } \\
\text { LBO Sociale verzorging en Horeca } \\
\text { (23) } \\
\text { Basisonderwijs (21) }\end{array}$ \\
\hline 55 & $\begin{array}{l}\text { Schoonmakers, } \\
\text { conciërges }\end{array}$ & $\begin{array}{l}\text { Basisonderwijs (39) } \\
\text { LBO Technisch (20) } \\
\text { MBO Technisch (10) }\end{array}$ & $\begin{array}{l}\text { Basisonderwijs (46) } \\
\text { LBO Sociale verzorging en Horeca } \\
\text { (27) }\end{array}$ \\
\hline
\end{tabular}




\begin{tabular}{|c|c|c|c|}
\hline \multicolumn{2}{|c|}{ Vrouwenberoep } & \multirow{2}{*}{$\begin{array}{l}\text { Mannen } \\
\text { Basisonderwijs (53) } \\
\text { MBO Technisch (16) }\end{array}$} & \multirow{2}{*}{$\begin{array}{l}\text { Vrouwen } \\
\text { Basisonderwijs (38) } \\
\text { LBO Sociale verzorging + Horeca } \\
\text { (31) }\end{array}$} \\
\hline 56 & Wasserijpersoneel & & \\
\hline 57 & $\begin{array}{l}\text { Kappers, schoon- } \\
\text { heidsspecialisten }\end{array}$ & $\begin{array}{l}\text { MBO Horeca }+ \text { Kappersopleiding }{ }^{1} \\
(52) \\
\text { MBO Sociale Verzorging (31) }\end{array}$ & $\begin{array}{l}\text { MBO Sociale Verzorging (47) } \\
\text { MBO Horeca- + Kappersopleiding } \\
\text { (36) }\end{array}$ \\
\hline 59 & $\begin{array}{l}\text { Dienstverlenende } \\
\text { functies n.e.g. }\end{array}$ & $\begin{array}{l}\text { Basisonderwijs (30) } \\
\text { LBO Technisch (18) } \\
\text { MBO Economisch + Administratief } \\
\text { (10) }\end{array}$ & $\begin{array}{l}\text { MBO Verpleging (42) } \\
\text { MAVO, onderbouw HAVO/VWO } \\
(12 \text { ) } \\
\text { Basisonderwijs (6) }\end{array}$ \\
\hline 79 & $\begin{array}{l}\text { Confectiemakers, } \\
\text { stoffeerders }\end{array}$ & $\begin{array}{l}\text { Basisonderwijs (33) } \\
\text { LBO Technisch }(25)^{2} \\
\text { MBO Technisch }(21)^{2}\end{array}$ & $\begin{array}{l}\text { LBO Sociale Verzorging + Horeca } \\
\text { (29) } \\
\text { Basisonderwijs }(24) \\
\text { MBO Technisch }(15)^{2} \\
\text { LBO Technisch }(15)^{2}\end{array}$ \\
\hline
\end{tabular}

1. Het gaat hier om (kappers)opleidingen waarmee men tevens de bevoegdheid om zich zelfstandig te vestigen kan betalen; bij de (kappers)opleidingen die vallen onder het opleidingstype MBO Sociale Verzorging kan men deze bevoegdheid niet halen!

2. Hierbij dient men zich te realiseren dat een aantal confectie-opleidingen in het leerlingwezen tot het technisch onderwijs wordt gerekend. 
Bijlage 11: De belangrijkste beroepen van beroepsoefenaren met vrouwenopleiding als opleidingsachtergrond naar sexe in 1985 (tussen haakjes: in procenten)

\begin{tabular}{|c|c|c|}
\hline Vrouwenopleiding & Mannen & Vrouwen \\
\hline $\begin{array}{l}\text { LBO Economisch + } \\
\text { Administratief }\end{array}$ & $\begin{array}{l}\text { Boekhoudkundige functies (22) } \\
\text { Overige administratieve functies (15) } \\
\text { Winkelbedienden (7) }\end{array}$ & $\begin{array}{l}\text { Overige administratieve functies } \\
(22) \\
\text { Secretaressen, typisten (17) } \\
\text { Boekhoudkundige functies (17) } \\
\text { Winkelbedienden (16) }\end{array}$ \\
\hline $\begin{array}{l}\text { LBO Sociale Verzorging } \\
\text { en Horeca }\end{array}$ & $\begin{array}{l}\text { Koks, kelners, serveersters (69) } \\
\text { Zelfstandige horecabedrijfhouders } \\
\text { (12) } \\
\text { Schoonmakers, conciërges (5) }\end{array}$ & $\begin{array}{l}\text { Huishoudelijk en verzorgend } \\
\text { personeel (19) } \\
\text { Winkelbedienden (17) } \\
\text { Schoonmakers, conciërges (13) } \\
\text { Koks, kelners, serveersters (9) }\end{array}$ \\
\hline MBO Verpleging & $\begin{array}{l}\text { Genees- en verpleegkundig } \\
\text { personeel }(88)\end{array}$ & $\begin{array}{l}\text { Genees- en verpleegkundig } \\
\text { personeel (64) } \\
\text { Dienstverlenende functies n.e.g. }{ }^{2} \\
\text { (10) } \\
\text { Huishoudelijk en verzorgend } \\
\text { personeel (7) }\end{array}$ \\
\hline $\begin{array}{l}\text { MBO Medisch } \\
\text { laboratorium }\end{array}$ & $\begin{array}{l}\text { Genees- en verpleegkundig } \\
\text { personeel }^{3}(30) \\
\text { Instrumentmakers, machine } \\
\text { bankwerker-monteurs (18) } \\
\text { Zelfstandige winkeliers (9) } \\
\text { Laboratoriumanalisten (7) }\end{array}$ & $\begin{array}{l}\text { Genees- en verpleegkundig } \\
\text { personeel }^{3} \text { (68) } \\
\text { Laboratoriumanalist (11) }\end{array}$ \\
\hline MBO Ziekenverzorging & $\begin{array}{l}\text { Genees- en verpleegkundig } \\
\text { personeel }(82)\end{array}$ & $\begin{array}{l}\text { Genees- en verpleegkundig } \\
\text { personeel ( } 73 \text { ) } \\
\text { Huishoudelijk en verzorgend } \\
\text { personeel (15) }\end{array}$ \\
\hline $\begin{array}{l}\text { MBO Sociale } \\
\text { Verzorging }\end{array}$ & $\begin{array}{l}\text { Genees- en verpleegkundig } \\
\text { personeel (26) } \\
\text { Kappers, schoonheidsspecialisten } \\
\text { (19) } \\
\text { Koks, kelners, serveersters ( } 8 \text { ) } \\
\text { Huishoudelijk en verzorgend } \\
\text { personeel (7) }\end{array}$ & $\begin{array}{l}\text { Huishoudelijk en verzorgend } \\
\text { personeel (33) } \\
\text { Genees- en verpleegkundig } \\
\text { personeel (19) } \\
\text { Kappers en schoonheidsspecialisten } \\
\text { (8) } \\
\text { Winkelbedienden (8) }\end{array}$ \\
\hline $\begin{array}{l}\text { HBO Verpleging en } \\
\text { Fysiotherapie }\end{array}$ & $\begin{array}{l}\text { Genees- en verpleegkundig } \\
\text { personeel }{ }^{4}(87)\end{array}$ & $\begin{array}{l}\text { Genees- en verpleegkundig } \\
\text { personeel }^{4}(88)\end{array}$ \\
\hline
\end{tabular}

1. In dit opleidingstype zit ook de LTS-opleiding kok/kelner begrepen.

2. Inclusief doktersassistenten.

3. Inclusief medisch laboranten.

4. Inclusief diëtisten. 


\begin{tabular}{lll}
\hline Vrouwenopleiding & Mannen & Vrouwen \\
\hline $\begin{array}{l}\text { HBO Medisch } \\
\text { laboratorium }\end{array}$ & Laboratoriumanalist (48) & Laboratoriumanalist (48) \\
& $\begin{array}{l}\text { Genees- en verpleegkundig } \\
\text { personeel }^{3}(22)\end{array}$ & $\begin{array}{l}\text { Genees- en verpleegkundig } \\
\text { personeel }\end{array}$ \\
& $\begin{array}{l}\text { Hogere schei-/naturkundig analisten } \\
\text { (15) }\end{array}$ & $\begin{array}{l}\text { Hogere schei-/naturkundig } \\
\text { analisten (6) }\end{array}$ \\
\hline
\end{tabular}

